\title{
\#USGS
}

National Water Quality Program

Design and Methods of the U.S. Geological Survey Northeast Stream Quality Assessment (NESOA), 2016

PENNSYLVANIA

Open-File Report 2018-1183

U.S. Department of the Interior

U.S. Geological Survey

CANADA
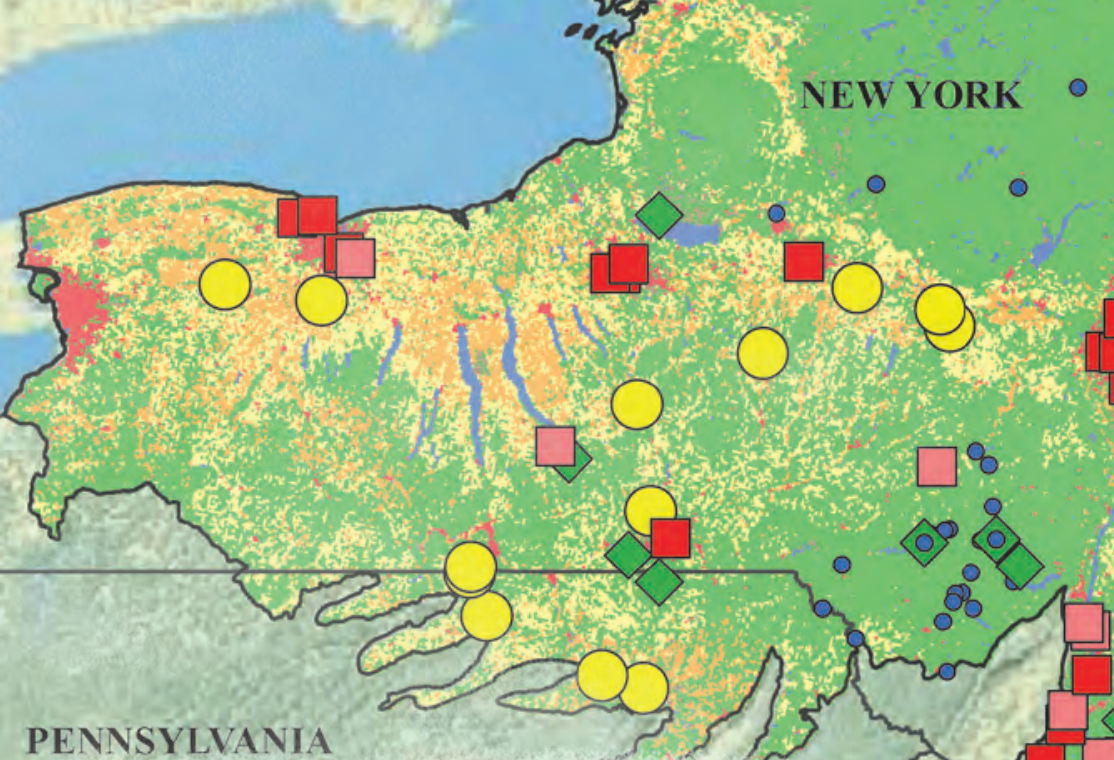

है 
Cover. Map of the Northeast Stream Quality Assessment study area, modified from figure $2 A$ of this report. 


\section{Design and Methods of the U.S. Geological Survey Northeast Stream Quality Assessment (NESQA), 2016}

By James F. Coles, Karen Riva-Murray, Peter C. Van Metre, Daniel T. Button, Amanda H. Bell, Sharon L. Qi, Celeste A. Journey, and Richard W. Sheibley

National Water Quality Program

Open-File Report 2018-1183 


\title{
U.S. Department of the Interior \\ DAVID BERNHARDT, Acting Secretary
}

\author{
U.S. Geological Survey \\ James F. Reilly II, Director
}

U.S. Geological Survey, Reston, Virginia: 2019

For more information on the USGS - the Federal source for science about the Earth, its natural and living resources, natural hazards, and the environment-visit https://www.usgs.gov or call 1-888-ASK-USGS.

For an overview of USGS information products, including maps, imagery, and publications,

visit https://store.usgs.gov.

Any use of trade, firm, or product names is for descriptive purposes only and does not imply endorsement by the U.S. Government.

Although this information product, for the most part, is in the public domain, it also may contain copyrighted materials as noted in the text. Permission to reproduce copyrighted items must be secured from the copyright owner.

Suggested citation:

Coles, J.F., Riva-Murray, K., Van Metre, P.C., Button, D.T., Bell, A.H., Qi, S.L., Journey, C.A., and Sheibley, R.W., 2019, Design and methods of the U.S. Geological Survey Northeast Stream Quality Assessment (NESQA), 2016: U.S.

Geological Survey Open-File Report 2018-1183, 46 p., https://doi.org/10.3133/ofr20181183.

ISSN 2331-1258 (online) 


\section{Contents}

Abstract

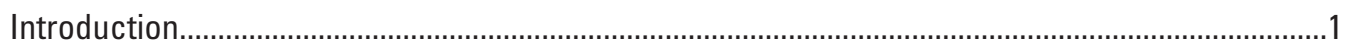

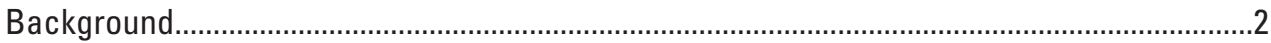

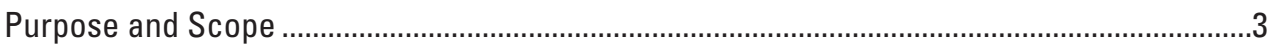

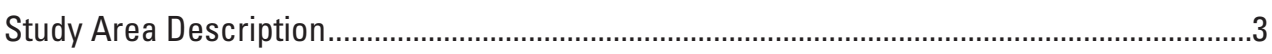

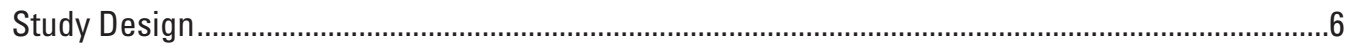

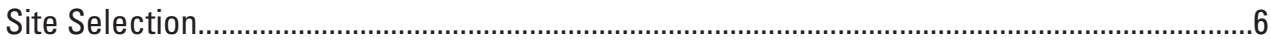

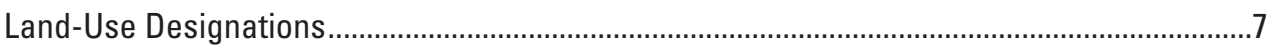

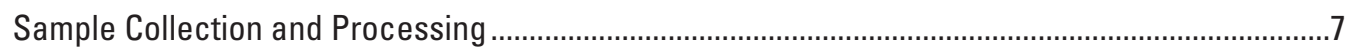

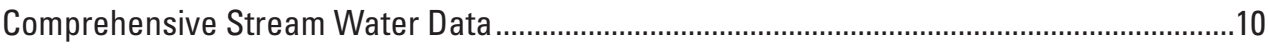

Discrete Water-Quality Samples......................................................................................

Continuous Water Temperature and Streamflow............................................................10

Polar Organic Compound Integrative Samplers ...............................................................11

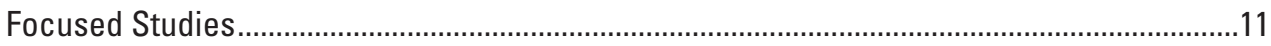

Sampling Pesticides With Small-Volume Pesticide Automated Samplers .....................12

Sampling Suspended Sediment With Walling Tube Samplers........................................12

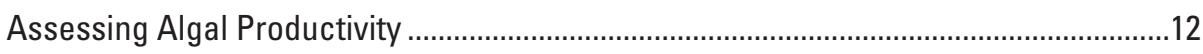

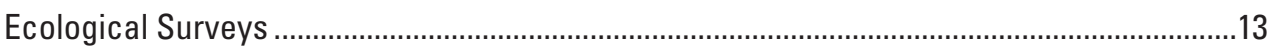

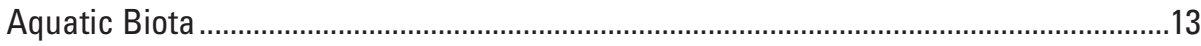

Fish Mercury Samples ..........................................................................................

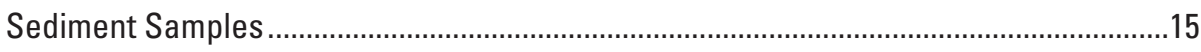

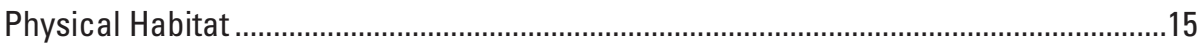

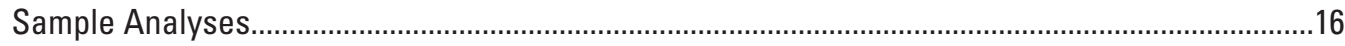

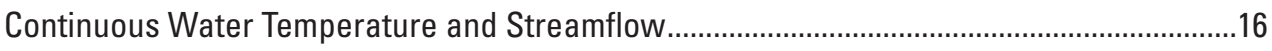

Chemical Analyses of Water, Sediment, and Fish ................................................................16

Discrete Water-Quality Samples.................................................................................16

Pesticides From the Small-Volume Pesticide Automated Samplers.................................17

Polar Organic Compound Integrative Samplers ..............................................................17

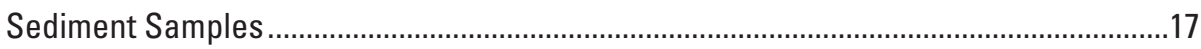

Periphyton Samples for Assessing Algal Productivity ...................................................18

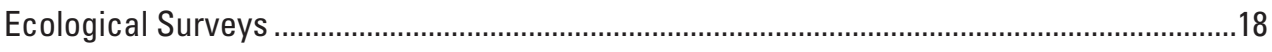

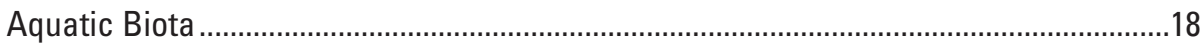

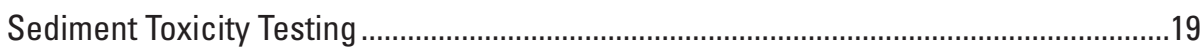

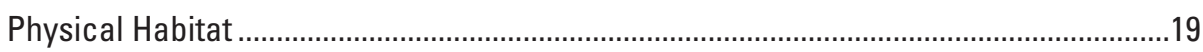

Quality Assurance and Quality Control ..................................................................................19

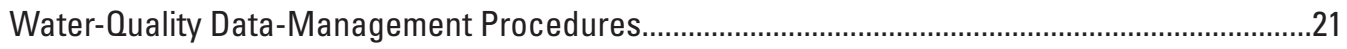

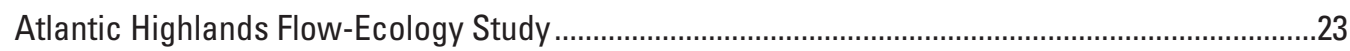

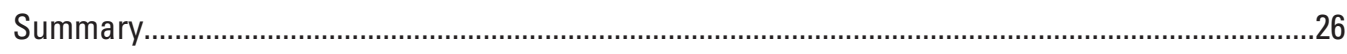

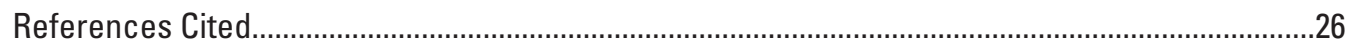

Appendix 1. Description of the Sampling Timelines, Matrix, Collection, and Processing for Water, Sediment, and Ecological Samples .....................................................................4

Appendix 2. Description of the U.S. Geological Survey National Water Quality Laboratory Schedules Used for Water, Sediment, and Periphyton.........................................................4 


\section{Figures}

1. Map showing locations of the Regional Stream Quality Assessment studies across the United States

2. Maps showing the Northeast Stream Quality Assessment (NESOA) study area.

3. Ternary diagram showing the relative percentages of undeveloped (mostly forested), urban, and agricultural land cover in watersheds of the 95 streams investigated for the Northeast Stream Quality Assessment (NESQA) in 2016

\section{Tables}

1. Characteristics of stream watersheds in the northeastern United States that were assessed as part of the U.S. Geological Survey Northeast Stream Quality Assessment in 2016

2. Summary of data collected at each of the Northeast Stream Quality Assessment sites in 2016.

3. Timeline of the sample collection by site type for the U.S. Geological Survey Northeast Stream Quality Assessment in 2016

4. Summary counts of environmental, field blank, replicate, and spike samples of stream water from the 95 stream sites sampled in the Northeast Stream Quality Assessment of the U.S. Geological Survey National Water-Quality Assessment Project in 2016.

5. Stream watersheds that were included in the Atlantic Highlands flow-ecology study, conducted by the U.S. Geological Survey as part of the National Water-Quality Assessment Project in 2014 


\section{Conversion Factors}

International System of Units to U.S. customary units

\begin{tabular}{|c|c|c|}
\hline Multiply & By & To obtain \\
\hline \multicolumn{3}{|c|}{ Length } \\
\hline centimeter $(\mathrm{cm})$ & 0.3937 & inch (in.) \\
\hline millimeter (mm) & 0.03937 & inch (in.) \\
\hline micrometer $(\mu \mathrm{m})$ & $3.937 \times 10^{-5}$ & inch (in.) \\
\hline nanometer (nm) & $3.937 \times 10^{-8}$ & inch (in.) \\
\hline meter $(\mathrm{m})$ & 3.281 & foot $(\mathrm{ft})$ \\
\hline kilometer $(\mathrm{km})$ & 0.6214 & mile (mi) \\
\hline meter $(\mathrm{m})$ & 1.094 & yard (yd) \\
\hline \multicolumn{3}{|c|}{ Area } \\
\hline square meter $\left(\mathrm{m}^{2}\right)$ & 0.0002471 & acre \\
\hline square meter $\left(\mathrm{m}^{2}\right)$ & 10.76 & square foot $\left(\mathrm{ft}^{2}\right)$ \\
\hline square centimeter $\left(\mathrm{cm}^{2}\right)$ & 0.1550 & square inch $\left(\mathrm{ft}^{2}\right)$ \\
\hline square kilometer $\left(\mathrm{km}^{2}\right)$ & 0.3861 & square mile $\left(\mathrm{mi}^{2}\right)$ \\
\hline \multicolumn{3}{|c|}{ Volume } \\
\hline microliter $(\mu \mathrm{L})$ & $2.642 \times 10^{-7}$ & gallon (gal) \\
\hline milliliter (mL) & 0.0002642 & gallon (gal) \\
\hline liter $(\mathrm{L})$ & 0.2642 & gallon (gal) \\
\hline liter (L) & 61.02 & cubic inch $\left(\right.$ in $\left.^{3}\right)$ \\
\hline microliter $(\mu \mathrm{L})$ & $6.102 \times 10^{-5}$ & cubic inch $\left(\right.$ in $\left.^{3}\right)$ \\
\hline \multicolumn{3}{|c|}{ Flow rate } \\
\hline meter per second $(\mathrm{m} / \mathrm{s})$ & 3.281 & foot per second $(\mathrm{ft} / \mathrm{s})$ \\
\hline \multicolumn{3}{|c|}{ Mass } \\
\hline gram (g) & 0.03527 & ounce, avoirdupois (oz) \\
\hline nanogram (ng) & $3.527 \times 10^{-11}$ & ounce, avoirdupois (oz) \\
\hline gram per square meter $\left(\mathrm{g} / \mathrm{m}^{2}\right)$ & 0.0002048 & pound per square foot $\left(\mathrm{lb} / \mathrm{ft}^{2}\right)$ \\
\hline milligram per square meter $\left(\mathrm{mg} / \mathrm{m}^{2}\right)$ & $3.277 \times 10^{-6}$ & ounce, avoirdupois, per square foot $\left(\mathrm{oz} / \mathrm{ft}^{2}\right)$ \\
\hline \multicolumn{3}{|c|}{ Pressure } \\
\hline kilopascal $(\mathrm{kPa})$ & 0.1450 & pound-force per inch (lbf/in [or psi]) \\
\hline
\end{tabular}

Temperature in degrees Celsius $\left({ }^{\circ} \mathrm{C}\right)$ may be converted to degrees Fahrenheit $\left({ }^{\circ} \mathrm{F}\right)$ as

$$
{ }^{\circ} \mathrm{F}=\left(1.8 \times{ }^{\circ} \mathrm{C}\right)+32
$$

Temperature in degrees Fahrenheit $\left({ }^{\circ} \mathrm{F}\right)$ may be converted to degrees Celsius $\left({ }^{\circ} \mathrm{C}\right)$ as

$$
{ }^{\circ} \mathrm{C}=\left({ }^{\circ} \mathrm{F}-32\right) / 1.8 .
$$

\section{Datum}

Horizontal coordinate information is referenced to the North American Datum of 1983 (NAD 83). 


\section{Supplemental Information}

Specific conductance is given in microsiemens per centimeter at 25 degrees Celsius $(\mu \mathrm{S} / \mathrm{cm}$ at $\left.25^{\circ} \mathrm{C}\right)$.

Concentrations of chemical constituents in water are given either in milligrams per liter $(\mathrm{mg} / \mathrm{L})$, micrograms per liter ( $\mu \mathrm{g} / \mathrm{L})$, or nanograms per liter (ng/L). Concentrations of chemical constituents in bed sediment are given in micrograms per kilogram $(\mu \mathrm{g} / \mathrm{kg})$.

\section{Abbreviations}

\begin{tabular}{ll} 
ASE & accelerated solvent extraction \\
ASR & analytical service request \\
CEC & Commission for Environmental Cooperation \\
CERC & Columbia Environmental Research Center \\
DAI & direct aqueous injection \\
DOC & dissolved organic carbon \\
ELISA & enzyme-linked immunosorbent assay \\
EPA & U.S. Environmental Protection Agency \\
ESI & electrospray ionization \\
GC/MS & gas chromatography mass spectrometry \\
GC-MS/MS & gas chromatography-tandem mass spectrometry \\
GIS & geographic information system \\
INSTAAR & Institute of Arctic and Alpine Research \\
LC-MS/MS & liquid chromatography tandem mass spectrometry \\
MRM & multiple reaction monitoring \\
NAWQA & National Water-Quality Assessment Project \\
NESOA & Northeast Stream Quality Assessment \\
NHDPlus & National Hydrography Dataset Plus \\
NLCD & National Land Cover Database \\
NWIS & National Water Information System \\
NWOL & National Water Ouality Laboratory \\
NYWSC & New York Water Science Center \\
OGRL & Kansas Organic Geochemistry Research Laboratory \\
OPP & Office of Pesticide Programs \\
OTU & operational taxonomic unit \\
PAH & polycyclic aromatic hydrocarbon \\
PAR & photosynthetically active radiation \\
\hline
\end{tabular}




$\begin{array}{ll}\text { PBDE } & \text { polybrominated diphenyl ether } \\ \text { PCB } & \text { polychlorinated biphenyl } \\ \text { PCFF } & \text { Personal Computer Field Form } \\ \text { POCIS } & \text { polar organic chemical integrative sampler } \\ \text { PVC } & \text { polyvinyl chloride } \\ \text { OA } & \text { quality assurance } \\ \text { OC } & \text { quality control } \\ \text { OW } & \text { quality of water } \\ \text { OWDATA } & \text { Water-Quality System within NWIS } \\ \text { OWDX } & \text { Water Quality Data Exchange } \\ \text { RP } & \text { reference point } \\ \text { RSQA } & \text { Regional Stream Quality Assessment } \\ \text { RTH } & \text { richest targeted habitat } \\ \text { TERL } & \text { Trace Elements Research Laboratory } \\ \text { THg } & \text { total mercury } \\ \text { USGS } & \text { U.S. Geological Survey } \\ \text { UVA } & \text { ultraviolet absorbance } \\ \text { WSC } & \text { Water Science Center }\end{array}$





\title{
Design and Methods of the U.S. Geological Survey Northeast Stream Quality Assessment (NESQA), 2016
}

\author{
By James F. Coles, Karen Riva-Murray, Peter C. Van Metre, Daniel T. Button, Amanda H. Bell, Sharon L. Qi, \\ Celeste A. Journey, and Richard W. Sheibley
}

\section{Abstract}

During 2016, as part of the National Water-Quality Assessment Project (NAWQA), the U.S. Geological Survey conducted the Northeast Stream Quality Assessment (NESQA) to investigate stream quality in the northeastern United States. The goal of the NESQA was to assess the health of wadeable streams in the region by characterizing multiple water-quality factors that are stressors to aquatic life and by evaluating the relation between these stressors and the condition of biological communities. Urbanization, agriculture, and human modifications to streamflow are anthropogenic changes that greatly affect water quality in the region; consequently, the study design primarily selected sites and targeted stressors associated with these activities. The NESQA built on a prior NAWQA study conducted in the region in 2014, the Atlantic Highlands flow-ecology study, which investigated the effects of anthropogenically modified flows on aquatic biological communities in primarily forested watersheds. Land-cover data for the NESQA were used to identify and select sites within the region that had watersheds ranging in levels of urban and agricultural development. A total of 95 sites were selected: 67 on streams in watersheds representing a range of urban land use, 13 on streams in watersheds with some degree of agricultural land use, and 15 on streams in predominantly forested watersheds with little development. Depending on land-cover characteristics, sites were sampled weekly for metal and organic contaminants, nutrients, and sediment for either a 9-week period that began the week of June 6, 2016, or a 4-week period that begin the week of July 11, 2016. Beginning August 1, 2016, and for about 2 weeks, an ecological survey was conducted at every site to assess stream habitat, and algal, benthic invertebrate, and fish communities. Additional samples collected during the ecological surveys were streambed sediment for chemical analysis and toxicity testing, and fish tissue for mercury analysis. This report describes the various study components and methods of the NESQA and describes a precursor effort for the Atlantic Highlands flow-ecology study. Details are presented for measurements of water quality, sediment chemistry, streamflow, and ecological surveys of stream biota and habitat, as well as processes of sample analysis, quality assurance and quality control, and data management.

\section{Introduction}

Many natural and anthropogenic stressors can affect stream ecosystems, and often the stressors that degrade streams are associated with the predominant land use in a region. Variations in streamflow, habitat, temperature, and levels of sediment and nutrients are essential characteristics of natural stream ecosystems, but deviation from the natural patterns of streams can substantially alter their biological condition and ecological function (Lenat and Crawford, 1994; Gregory and Calhoun, 2006; Nagy and others, 2011). Contaminants differ from other stressors in that most are derived from human activities and, through various modes of action and toxicity, are potentially detrimental to aquatic life as well as to humans who use water resources. In order to efficiently manage water resources, it is important to understand the conditions under which stressors - individually or in combinations - adversely affect the biological condition of streams and the water resources valued by people.

Multistressor effects are often assessed in the laboratory under controlled conditions or in the field at small-catchment scales. At these small scales, biogeochemical processes and complex environmental interactions can be manipulated and monitored; however, results of such studies are not readily extended over larger spatial scales. Alternatively, by characterizing the conditions of multiple streams over a broad spatial area, specific stressors and biological conditions can be evaluated on regional and national scales (U.S. Environmental Protection Agency, 2006; Herlihy and others, 2008); from such studies, empirical models have been developed to predict metrics of biological condition and environmental stressors across national-scale disturbance gradients (Waite and others, 2000; Klemm and others, 2003; Herlihy and others, 2006; Coles and others, 2012). To date, however, most regional- and nationalscale studies have not included a thorough characterization of stressors but have limited their evaluations to relations between land use and biological condition.

The U.S. Geological Survey (USGS), through the National Water-Quality Assessment Project (NAWQA), is conducting studies to bridge this gap, through extensive stressor characterizations at large spatial scales that include multiple sampling sites to promote development of empirical models. As such, the studies are intended to provide communities and 
policymakers with information about the human and environmental factors that have the greatest effects on stream quality by addressing these objectives:

1. Determine the status of stream quality across the region on the basis of contaminants, nutrients, sediments, toxicity of the bed sediments, streamflow, habitat, and biological communities.

2. Evaluate the relative influence of contaminants, nutrients, sediment, toxicity, streamflow, and habitat on biological communities in the streams.

3. Evaluate how the natural and anthropogenic characteristics of the watersheds are related to stressors measured at the stream-reach scale and how the condition of biological communities can be explained by these stressors.

4. Develop statistical models and management tools to predict the ecological health of wadeable streams throughout the region and how it is associated with concentrations of contaminants, nutrients, and sediment.

\section{Background}

The USGS launched Cycle III of the NAWQA in 2013, which marked the beginning of NAWQA's third decade of water-quality assessments for the Nation. In 1992, Cycle I of NAWQA began investigations with an emphasis on characterizing the Nation's streams and aquifers through a routine monitoring program to establish baseline conditions. A decade later, NAWQA transitioned to Cycle II, which emphasized trends and modeling and included five "topical" studies designed to improve our understanding of environmental processes. The topical studies addressed (1) the fate and transport of agricultural chemicals, (2) effects of urbanization on stream ecosystems, (3) effects of nutrient enrichment on stream ecosystems, (4) transport of contaminants to public-supply wells, and (5) bioaccumulation of mercury in stream ecosystems.

Cycle III is built on 20 years of NAWQA studies that describe linkages between contaminant sources and their transport to receiving waters and the effects of land use on stream quality and ecological condition.

Among the major objectives in Cycle III is to assess the occurrence and effects of multiple instream stressors on stream quality. Termed Regional Stream Quality Assessment (RSQA) studies, these studies are characterizing watershed and stream water-quality stressors and aquatic biological conditions to improve understanding of stressor-effects relations at regional scales (https://webapps.usgs.gov/RSQA/). Each RSQA study is a short-term assessment of wadeable streams within a targeted, multistate region, generally delineated by U.S. Environmental Protection Agency (EPA) ecoregions (Omernik and Griffith, 2014). About 100 streams are sampled in each RSQA study to investigate stream ecology and the influences of multiple physical and chemical stressors that are primarily associated with urban development and agricultural land use.
Wadeable streams are selected across gradients in urban or agricultural land use or both, depending on the dominant land uses in the region. Weekly water sampling was conducted for 4 to 12 weeks (depending on region and site) for a wide range of chemical constituents, as well as continuous monitoring of flow or stage and temperature in the streams. The timing of this water-quality "index period" is designed to capture the spring and early summer growing season when pesticide and fertilizer applications are highest. The water-quality index period culminates with collection of streambed sediment for extensive chemical analyses and toxicity testing, and with an ecological survey to assess stream habitat and algal, invertebrate, and fish communities.

In 2016, an RSQA study was conducted as part of the NAWQA to assess stream quality across the Northeast region of the United States. Designated as the Northeast Stream Quality Assessment (NESQA), this study was the fourth of the five NAWQA Cycle III regional studies (fig. 1); others were the Midwest Stream Quality Assessment in 2013 (U.S. Geological Survey, 2012), the Southeast Stream Quality Assessment in 2014 (Van Metre and Journey, 2014), the Pacific Northwest Stream Quality Assessment in 2015 (Van Metre, and others, 2015), and the California Stream Quality Assessment in 2017 (Van Metre, Egler, and May, 2017). The study area for the NESQA included 95 watersheds in 8 States: Connecticut, Massachusetts, New Hampshire, New Jersey, New York, Pennsylvania, Rhode Island, and Vermont (fig. 2A; table 1, in back of report). Like the preceding RSQA studies, the 2016 NESQA primarily investigated stressors associated with urban development, which is particularly intense along the corridor from Boston, Massachusetts, to New York City, New York, and agriculture, which is concentrated mainly in watersheds across the southwestern area of the NESQA region (New York and Pennsylvania).

A related NAWQA study, on which the 2016 NESQA study was built, was the Atlantic Highlands flow-ecology study conducted in 2014 at 66 sites in the Atlantic Highlands ecoregion to assess how flow alterations affected biological communities. The Atlantic Highlands is a Level II ecoregion that is based on ecoregion designations by the Commission for Environmental Cooperation (CEC) in North America (Omernik and Griffith, 2014), and it closely corresponds to the EPA Level III Northeastern Highlands ecoregion. The Atlantic Highlands (and thus Northeastern Highlands) includes the higher elevation sections in the NESQA study area, mainly across the more northern latitudes (fig. 2B); this area is generally less developed and more heavily forested than other ecoregions in the Northeast, and it has many streams whose flow has been anthropogenically altered to create water supplies, hydropower, recreational areas, and flood controls. Consequently, the Atlantic Highlands flow-ecology study was conducted to assess how biological communities were affected specifically by stressors associated with altered streamflows in otherwise low-disturbance streams. To help provide a context with the 2016 NESQA study, an overview of the Atlantic Highlands flow-ecology study is provided in a separate section near the end of this report. 


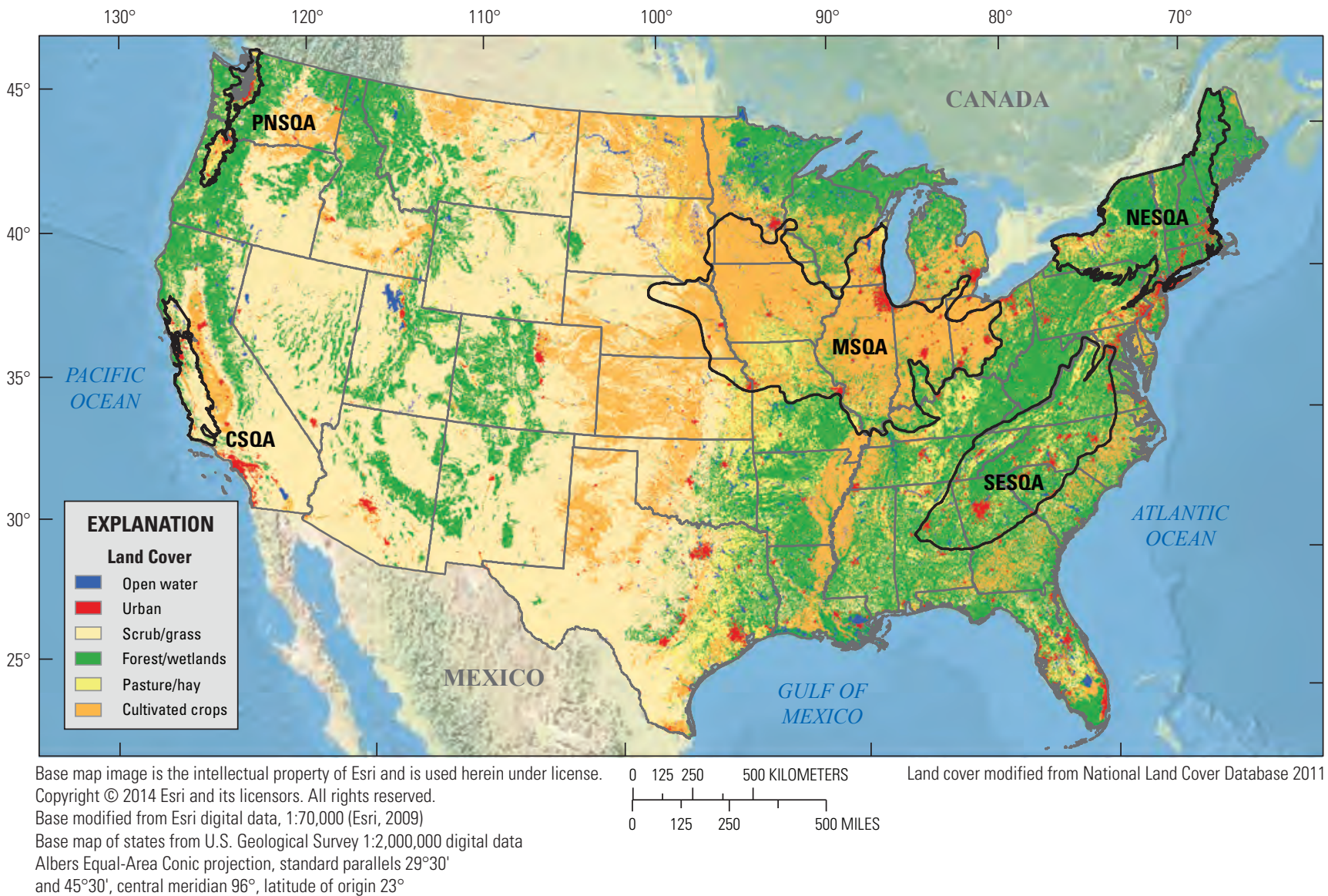

Figure 1. Locations of the Regional Stream Quality Assessment studies across the United States. CSQA, California Stream Quality Assessment; MSQA, Midwest Stream Quality Assessment; NESQA, Northeast Stream Quality Assessment; PNSQA, Pacific Northwest Stream Quality Assessment; SESQA, Southeast Stream Quality Assessment.

\section{Purpose and Scope}

This report describes the design and methods of the NESQA, a study in the northeastern United States incorporating a network of 95 stream sites sampled over several weeks during late spring and summer of 2016 to evaluate stream conditions related to water quality, sediment quality, biological communities, streamflow, water temperature, and habitat characteristics. The methods described include the collection and processing of several kinds of water-quality samples and ancillary data, the discussion of which is divided into three parts: comprehensive data collected at all sites, data collected at selected sites as part of focused studies, and data collected in the ecological surveys that took place at the end of the study period. The report also describes methods of laboratory analysis and other data processing, quality assurance and quality control procedures, and data management procedures. A precursor study in the Northeast that was completed in 2014, the Atlantic Highlands flow-ecology study, is summarized near the end of the report.

\section{Study Area Description}

The 95 NESQA streams sampled in 2016 were initially selected, in part, to constrain natural variably among sites to the extent practicable. A map of the CEC Level II ecoregion designations was used for this purpose because land-cover delineations at this level are based on environmental characterizations assessed at a broad regional scale (Wiken and others, 2011). As a result, the watersheds of the NESQA streams were in three CEC Level II ecoregions: 76 stream sites were in Mixed Wood Plains, 17 sites were in Atlantic Highlands, and 2 sites were in the northernmost part of Southeastern USA Plains. The NESQA sites were also categorized by EPA Level III ecoregions so that the streams could be defined in environmental terms with greater precision (table 1 , in back of report; fig. $2 B$ ). Much of the following information that describes the EPA Level III ecoregions within the NESQA study area is summarized from Wiken and others (2011), and further details are in that publication.

The Northeastern Coastal Zone had 52 NESQA sites, generally defines the eastern and southern boundaries of the 


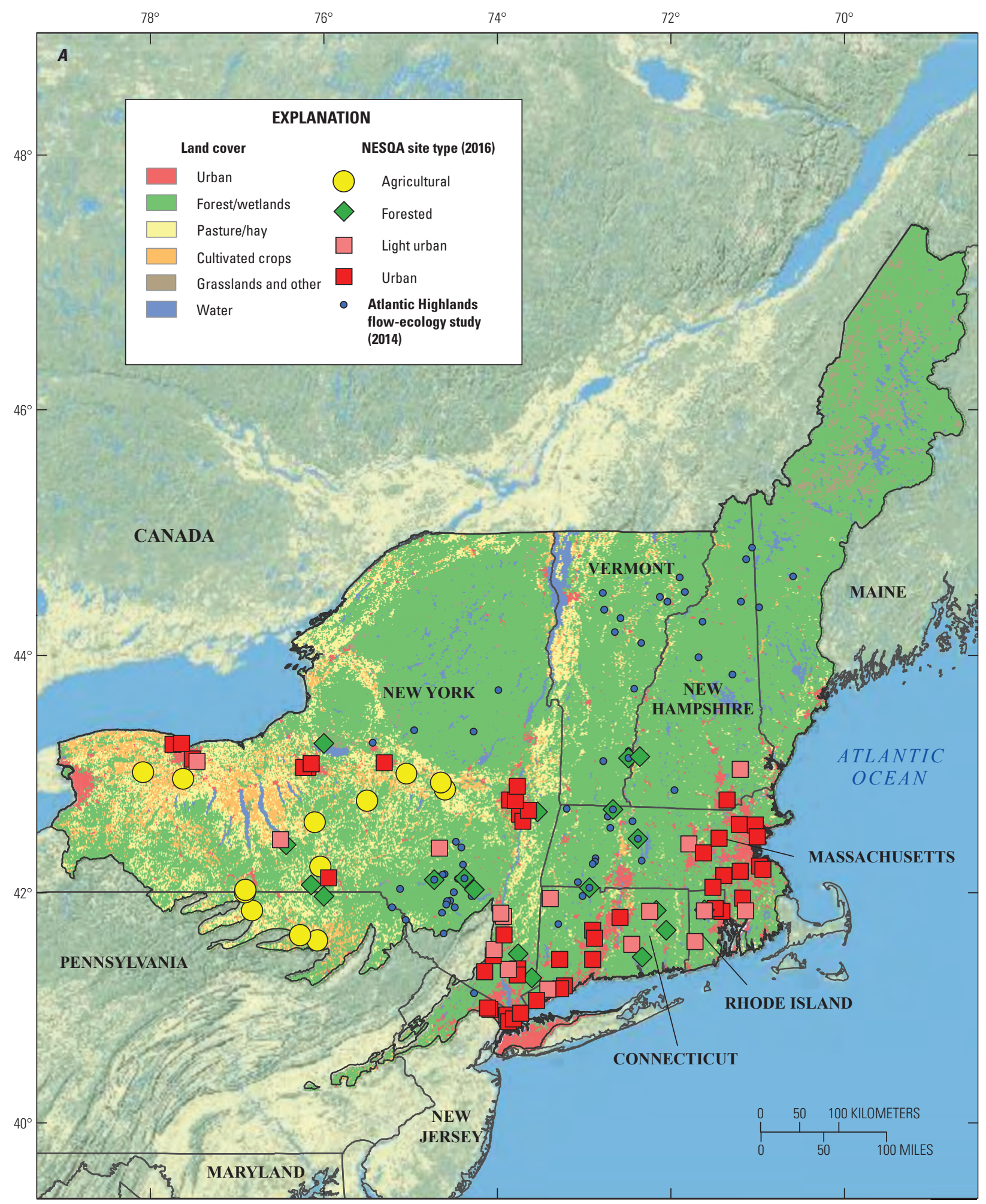

Base map image is the intellectual property of Esri and is used herein

Land cover modified from National Land Cover Database 201 under license Copyright (C) 2014 Esri and its licensors. All rights

reserved. Base modified from Esri digital data, 1:70,000 (Esri, 2009)

Web Mercator Projection World Geodetic System of 1984 (WGS 84)

Figure 2. The Northeast Stream Quality Assessment (NESQA) study area. $A$, sampling locations and generalized land cover. B, U.S. Environmental Protection Agency (EPA) Level III ecoregions. In 2016, 95 streams in urban, agricultural, and forested settings were sampled. As part of the Atlantic Highlands flow-ecology study in 2014, 66 streams in forested settings were sampled; 6 of these streams were also part of the NESOA site network, which are indicated by a green diamond with a blue dot. Site types are defined in table 1, footnote 3. 


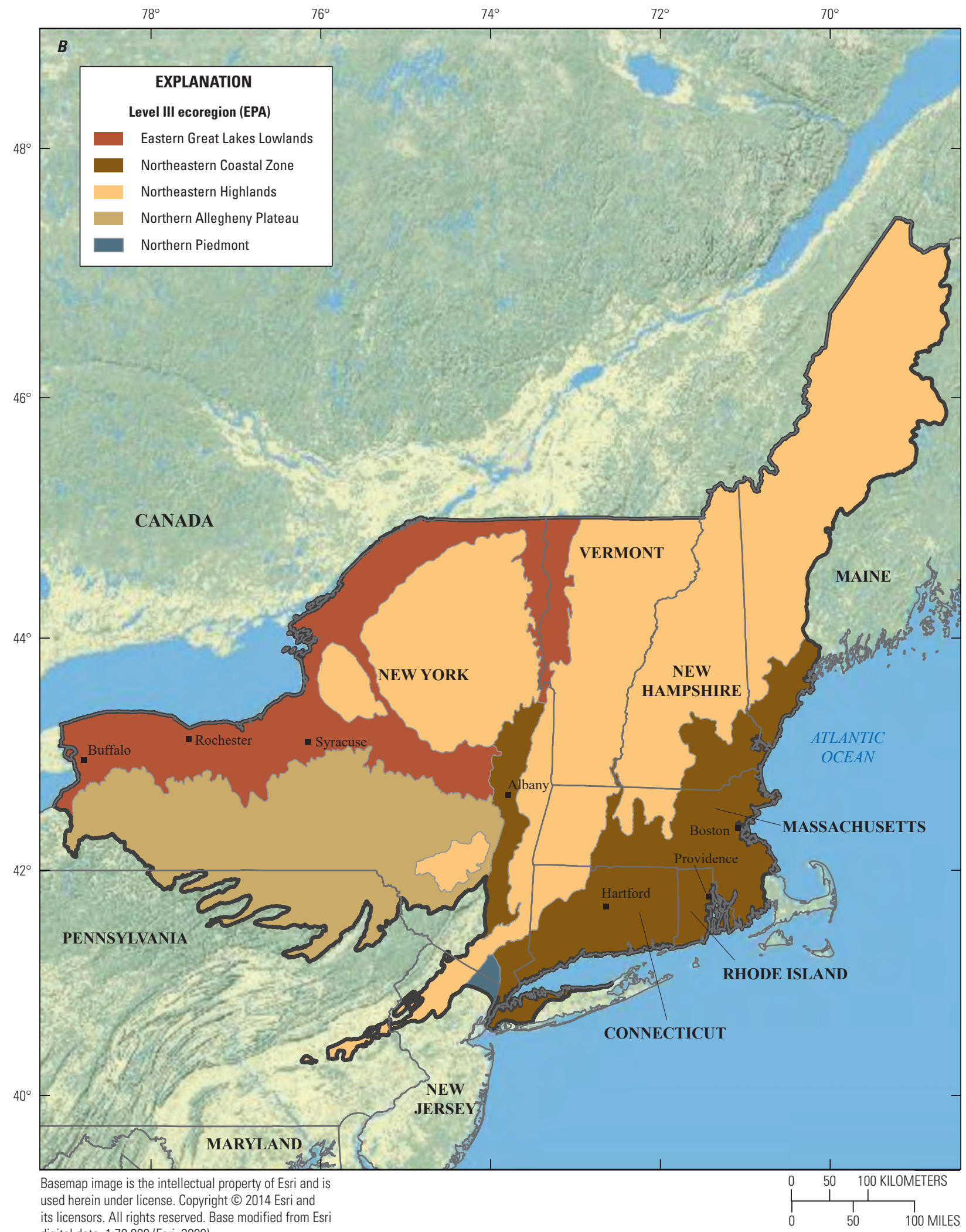

digital data, 1:70,000 (Esri, 2009)

Figure 2. The Northeast Stream Quality Assessment (NESQA) study area. $A$, sampling locations and generalized land cover. B, U.S. Environmental Protection Agency (EPA) Level III ecoregions. In 2016, 95 streams in urban, agricultural, and forested settings were sampled. As part of the Atlantic Highlands flow-ecology study in 2014, 66 streams in forested settings were sampled; 6 of these streams were also part of the NESOA site network, which are indicated by a green diamond with a blue dot. Site types are defined in table 1, footnote 3.-Continued 
NESQA region, and encompasses the urban corridor of Boston, Mass., Providence, Rhode Island, Hartford, Connecticut, and New York City, N.Y. This ecoregion has much greater concentrations of human population than does the westerly adjacent ecoregion, the Northeastern Highlands. Attempts were made to farm much of the Northeastern Coastal Zone after the region was settled by Europeans, but land use now mainly consists of urban and suburban development, regrowth forests and woodlands, and only small areas of pasture and cropland.

The Eastern Great Lakes Lowlands had 14 NESQA sites and extends over the lowlands centered on the lower reaches of the St. Lawrence and Hudson Rivers. This ecoregion, being characterized by lowlands, surrounds sections of the Northeastern Highlands ecoregion in New York and defines the western boundary of the NESQA region. Although some urban centers are in this ecoregion, such as Syracuse, Rochester, and Buffalo, N.Y., 60 percent of the ecoregion is intensively cultivated farmland with the dominant farming systems being mixed, dairy, and cash crops. Major crops include grains, corn, soybeans, hay, and fruits and vegetables; orchards and vineyards are also important for the region.

The Northern Allegheny Plateau had 14 NESQA sites, defined the southwest boundary of the NESQA region, and included parts of southern New York and northern Pennsylvania. The terrain is glaciated upland plateau, which contains rolling hills, open valleys, and low mountains, and the geology is mostly shales, siltstones, and sandstones. Urban development is relatively low in this ecoregion, although it does have multiple towns and small cities. Much of this ecoregion can be characterized generally as a mosaic landscape that has farms interspersed with areas of woodlands and forest. The principal crops of the farms are pasture, hay, and grain for beef and dairy cattle.

The Northeastern Highlands had 13 NESQA sites, 6 of which were also sampled for the 2014 Atlantic Highlands flow-ecology study. This Level III ecoregion covers most of the northern and mountainous parts of New England, as well as the Adirondack and Catskill Mountains in New York State. More forest-covered than the adjacent ecoregions, it has considerable variety in its tree species and has many moderateto-high-gradient perennial streams. A primary reason sites were chosen in this ecoregion is that it has many streams with forest-dominated watersheds that are minimally disturbed by human land use. The streams in this ecoregion that were used in the Atlantic Highlands flow-ecology study collectively represented a gradient of low to high levels of flow alteration. However, the 2016 NESQA sites in this ecoregion were at the low end of the flow-alteration gradient and, therefore, were among the least disturbed sites in the NESQA study.

Two NESQA sites in New Jersey were in the Northern Piedmont. This ecoregion extends as far north as northern New Jersey and extends through that State as a narrow band bordered on the west by the Northern Appalachian Plateau ecoregion and on the east by the Atlantic Maritime Highlands and the Northeastern Coastal Zone ecoregions; thus, the
Northern Piedmont generally is situated between mountain ranges and the coastal plain. The climate in this area of the Northern Piedmont generally is marked by hot summers and cold winters, it has low to moderate gradient perennial streams, and topography can be characterized as having low, rounded hills. Pre-Columbian vegetation was predominately Appalachian oak forests but now includes chestnut oak, white oak, red oak, hickories, ash, elm, and yellow-poplar; eastern red cedar is common on abandoned farmland. Mostly agriculture and urban, suburban, and industrial uses prevail, but in the vicinity of the NESQA sites, land cover is primarily developed, including urban and suburban land uses.

\section{Study Design}

The NESQA study was designed to assess differences in stream quality that were associated with urban development and agriculture in the region and to identify and measure specific stressors linked to those land uses. The NESQA study expanded on the 2014 Atlantic Highlands flow-ecology study that assessed changes in the quality of Northeast streams relative to the type and extent of flow-regime modifications.

Of the 95 NESQA stream sites that were sampled during 2016, 63 were primarily selected to characterize the effects of urban development and associated stressors on stream health, and 17 were selected to characterize the effects of agriculture and associated stressors on stream health; additionally, 15 sites were predominantly forested, with less than 1 percent of urban and less than 5 percent agricultural land use in their watersheds, and these sites were used to help establish "least developed" conditions for most stressors examined here. The network of 67 urban-development sites represented a gradient design, in which the watersheds represented a range of urban development from near zero to 99 percent. The 13 agricultural sites were incorporated in a group design, which grouped sites in 1 of 3 categories based on the relative percentage of agricultural land use in the watershed ( 1 to 5 , greater than 5 to 15 , and greater than 15 percent). The forested sites were used in conjunction with both the urban and agricultural sites, either to characterize the least developed end of the urban gradient or near-reference conditions for the agricultural gradient.

\section{Site Selection}

Only wadeable streams were considered for the study because they generally had a depth of about $1 \mathrm{~m}$ or less during low flow, which is shallow enough to be sampled by wading. In selecting streams for the NESQA study, candidate sites were identified first from active and historical (inactive) USGS streamgages, then from other USGS sampling sites and from monitoring sites used by State and local agencies. Several sites that had not been previously sampled were also selected to fill gaps in the distribution of land-use settings relative to design objectives. A geospatial database was created that included 
land-cover characteristics for the watersheds of all candidate sites. Watershed delineations and characteristics were available for active USGS streamgages; however, for other candidate sites, catchment boundaries from the National Hydrography Dataset Plus were used as the watershed boundaries by selecting all upstream catchments from the segment on which the candidate site was located (NHDPlus Version 2; U.S. Environmental Protection Agency, 2012). Nationally available, digital geographic information systems (GIS) data layers (for example, the National Land Cover Database [NLCD], Homer and others, 2015) were overlain on the catchment-derived watersheds, and then characteristics of the watersheds were assessed and summarized from these data layers.

Initially, 630 sites were identified in the NESQA region. These were subsequently evaluated with the use of Google Earth satellite imagery (https://www.google.com/earth/) for general watershed characteristics related to land cover and geomorphology, potential stressor sources (for example, water treatment plants, industrial complexes, golf courses), and sampling reach locations. From this procedure, 178 sites were selected as potential sampling streams that collectively represented forest, agricultural, and urban development land uses. An instream reconnaissance of these sites was conducted by USGS staff during the summer of 2015 ; field observations for each site included evaluating the site for access and safety, assessing general stream characteristics to determine a watersampling location, and identifying a 150 -meter $(\mathrm{m})$ stream reach with riffle habitat suitable for conducting ecological surveys. Information that was documented included stream accessibility, location and description of the nearest bridge for water-chemistry sampling during high flows, stream-reach wadeability, streambed substrate, instream habitat complexity, presence of discharge pipes and other obvious point sources, potential landowner contacts, and photographs of the stream. Field notes and photography were recorded onsite by using field-reconnaissance forms on an electronic tablet; afterwards, information from these forms was compiled into spreadsheets for use in site review for final selection.

\section{Land-Use Designations}

The designations of the three types of NESQA sitesurban development, agricultural, and forested undevelopedwere based on percentages of land cover in their watersheds (fig. 3). Candidate urban-development sites were selected on the basis of the percentage of urban land use and lack of substantial (about 5 percent or less) agricultural row-crop land use from the 2011 NLCD data (U.S. Geological Survey, 2014; Homer and others, 2015). To ensure that the network of urban-development sites characterized a gradient of urbanization from low to high levels, sites were selected to fit within one of five categorical "tiers" that each represented a different range of watershed urban land cover: tier 1, 1-10 percent (considered "light urban"); tier 2, greater than 10-20 percent, tier 3, greater than 20-37.5 percent; tier 4, greater than
$37.5-50$ percent; and tier 5 , greater than 50 percent (table 1 , in back of report). The 67 sites selected for the urban-development gradient were distributed across the 5 tiers so that incremental levels of urban development were represented. Urban development in the region is concentrated along the southern corridor of the NESQA region that included the metropolitan areas of Boston, Mass., Providence, R.I., Hartford, Conn., and New York City, N.Y. (fig. 2B), but urban centers located elsewhere in the region were also included (for example, Albany, Syracuse, and Rochester, N.Y.). In addition, the predominantly forested sites along this section of the NESQA region were used in the urban-development gradient to represent least developed conditions.

Agricultural sites were selected to represent the major crop-producing areas in the western NESQA region (fig. $2 A$ ), and priority was given to sites in watersheds where agricultural chemical use was expected to be high on the basis of the crop type grown. Unlike the gradient design used to characterize increasing levels of urban development among sites, the agricultural network of 13 sites included 2 categories that each represented a range of land-use percentages in cultivated row crops: low Ag, 5 to 15 percent agriculture, and Ag, greater than 15 percent agriculture (table 1, in back of report). In addition, 4 of the 15 "Forested" sites had very low agriculture, 1 to 5 percent, and these supplemented the agricultural site groups (forming a third agricultural group). The balance of land use in the watersheds of most of these sites with very low agriculture was primarily forest with very little urban development. Additionally, the remaining 11 of the 15 NESQA forested sites helped to characterize least disturbed stream conditions for comparison with conditions of the agricultural sites and to help approximate predevelopment conditions along the urban gradient (fig. 3). It is important to note that the categorical designations used for selecting the sites were based on cursory reviews of watershed features and that more rigorous GIS procedures were used later to more accurately characterize and define the sites.

\section{Sample Collection and Processing}

To allocate resources effectively among the 95 NESQA sites, the frequency of water-quality sampling varied by the intensity of development in the watershed. The predominately forested sites were sampled weekly during the 4-week period that began on July 11, 2016. All 45 urban sites and 6 of the 22 light urban sites were sampled weekly for the 9-week period that began on June 6, 2016; 16 of light urban sites that were sampled only during the 4-week period. Of the 13 agricultural sites, the 8 representing the highest level (greater than 15 percent row crop) were sampled weekly over the 9-week period, whereas the sites representing the low levels (5 sites) of agriculture were sampled weekly only during the 4-week period. Further information about the sampling frequency at each site is provided in tables 2 (in back of report) and 3. 


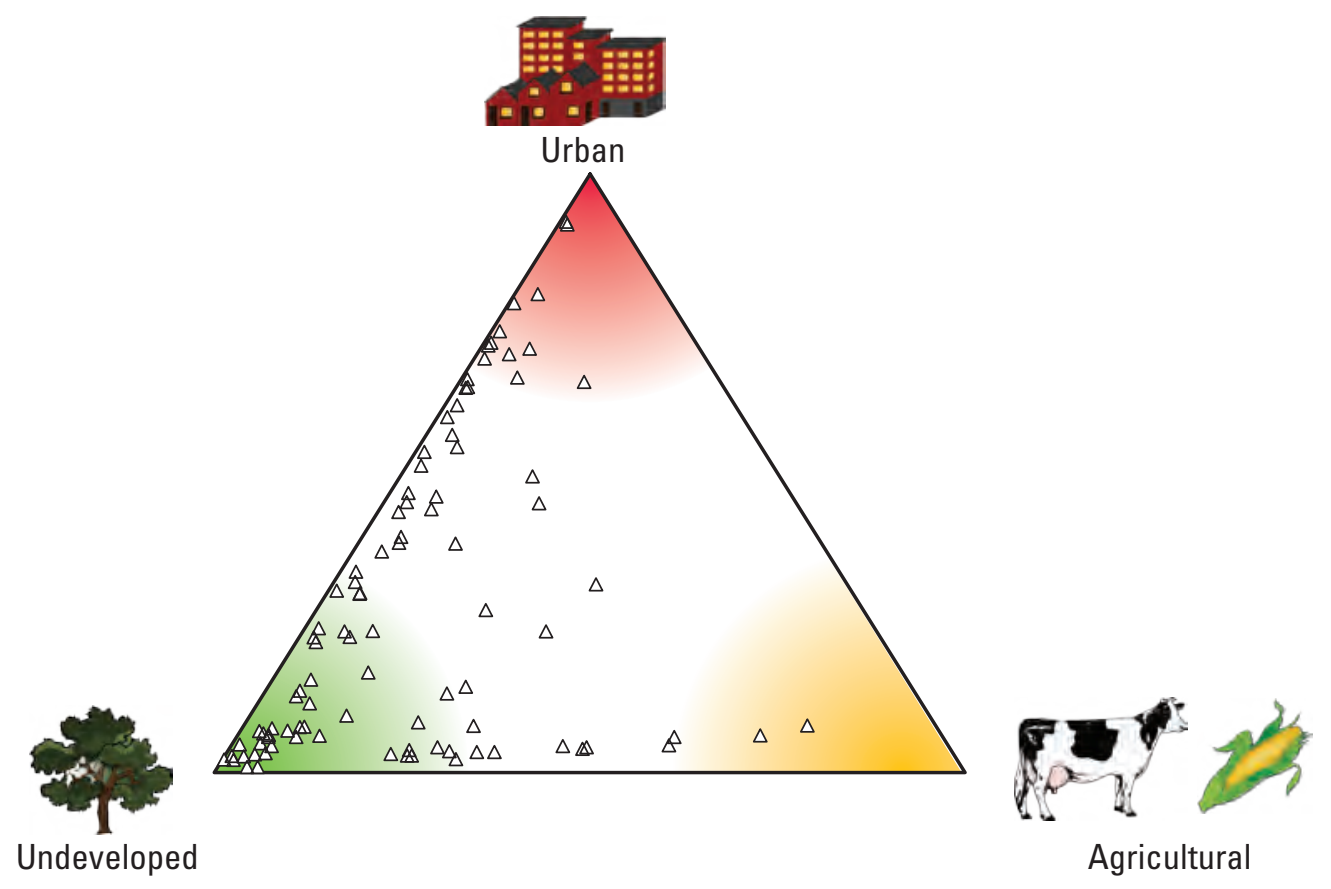

Figure 3. The relative percentages of undeveloped (mostly forested), urban, and agricultural land cover in watersheds of the 95 streams investigated for the Northeast Stream Quality Assessment (NESQA) in 2016. Each of the three points of the diagram represents 100 percent of the respective land-cover type. If a site had equal amounts of urban, agriculture, and undeveloped land cover, it would be centered in the diagram. Colors are for visual effect.

The types of data and the intervals at which samples were collected varied among the NESQA sites according to landcover type and associated potential stressors. Data collection routines were categorized nominally by three study-design components (table 2, in back of report). The comprehensive stream water data component began the week of June 6, 2016 (at 59 sites), or the week of July 11, 2016 (at 36 sites), and continued through the week of August 8, 2016. During the sampling period, water temperature and streamflow were recorded at all sites (by data-logging instrumentation, typically on a 1-hour interval), and water-quality samples were collected weekly. The focused studies component included several investigations at subsets of NESQA streams that were focused on the occurrence and timing of specific stressors that could affect the condition of those streams; these studies are described below. The ecological survey component occurred within a 2-week period that began August 1, 2016: at each stream along a $150-\mathrm{m}$ sampling reach during, assessments were made of the physical habitat and biological communities, and samples were collected for chemical analysis of sediment and mercury contamination in fish.

In addition to being characterized by study-design component, data were defined by the time interval at which they were collected: discrete, integrated, or continuous, depending on the parameter being measured (table 2, in back of report). Discrete data characterized conditions at a given date and time and could be collected once, as represented by streambed sediment samples collected during the ecological survey, or at discrete intervals, as represented by water-quality samples collected weekly. Integrated data represented "average" conditions over the time period the sampler was deployed, as was the case with the polar organic chemical integrative sampler (POCIS), described in the section "Polar Organic Compound Integrative Samplers." Continuous data were water-quality parameters recorded at short but regular time intervals throughout a sampling period, as was the case with stream temperature, which was recorded hourly.

USGS staff who participated in the NESQA study received intensive training prior to any data collection activities, including instructions specific to water-quality sampling, the focused studies, and ecological surveys. For example, the use of low-level analytical methods necessitated that water samples be collected according to "parts-per-billion" protocols (U.S. Geological Survey, 2006). During weeks when water-quality data were collected at all 95 sites, as many as 10 two-person teams of USGS staff were deployed. Thus, to ensure consistency among the water-quality teams, training for the collection and processing of water-quality samples occurred in May 2016 for all personnel involved with sample collection. Classroom water-quality training was followed by field-training exercises to work through all sampling and processing procedures in the field prior to the start of sampling. The sample collection timelines (table 3), sample types collected at sites, and sample collection, processing, and handling procedures are summarized in appendix 1 and described briefly here. 


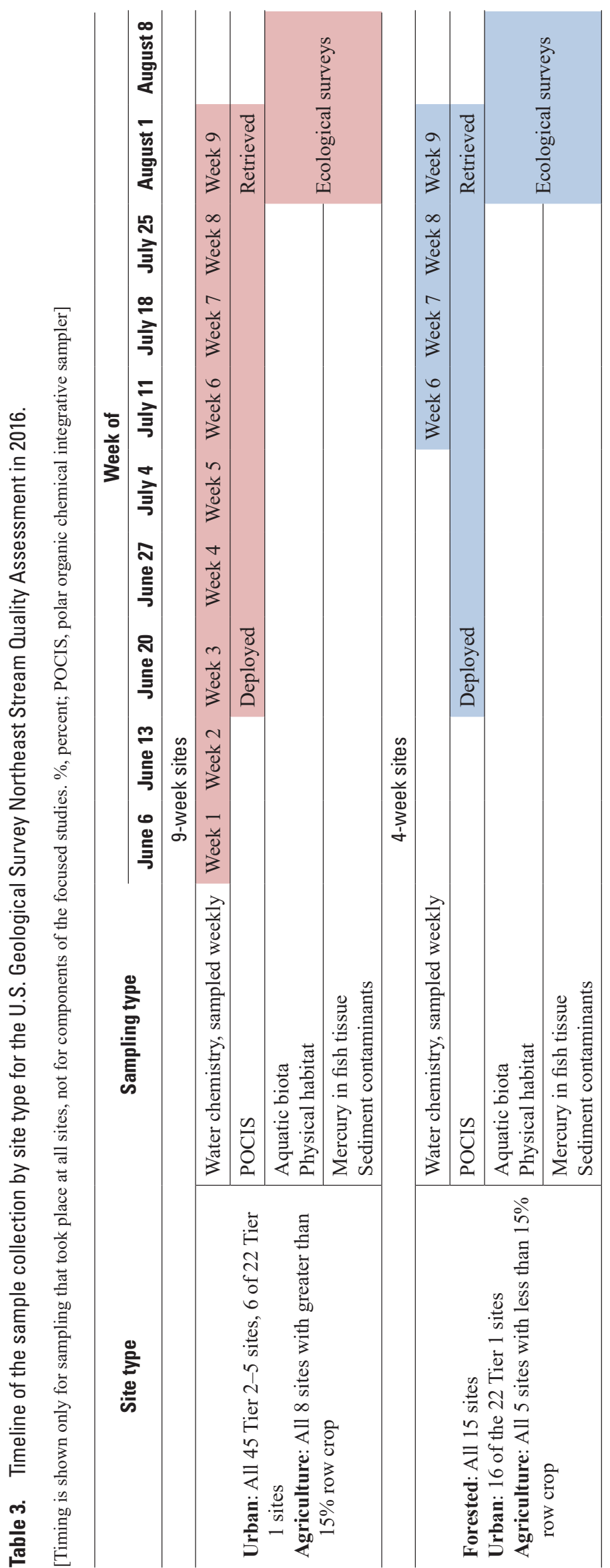




\section{Comprehensive Stream Water Data}

To help characterize stream conditions in a consistent manner among NESQA sites, a comprehensive suite of samples and ancillary data were collected at each location over several weeks during the course of the NESQA study. Discrete water-quality samples were collected for a 9-week QW (quality of water) sampling period at 59 sites and a 4-week QW sampling period at 36 sites (tables 2, in back of report, and 3 and appendix 1, table 1.1). Continuous readings of water temperature and streamflow were collected at all sites for up to a year (including the QW and ecological sampling periods). Discharge was recorded at sites that had active USGS streamgages, and pressure transducers were installed to record stream stage during the QW and ecological sampling periods (or longer) at sites without active streamgages (table 2, in back of report). Polar organic chemical integrative samplers (POCISs) were deployed at all sites for about 6 weeks during the QW sampling period; the POCISs provided estimates of the average concentrations of certain organic chemicals over the deployment period. These samples and how they were collected are described in more detail in the following sections.

\section{Discrete Water-Quality Samples}

Weekly discrete water-quality samples were collected according to the following basic laboratory schedules: nutrients, major ions, dissolved organic carbon, pesticides, glyphosate by immunoassay, and suspended-sediment concentration. This group of schedules is referred to as BASIC for the weekly sampling routines, whereas additional chemical parameter groups were sampled on selected weeks (appendix 1, table 1.1). The parameter groups included in a sampling event and frequency of sample collection varied by site type so that potential stressors could be associated with land-use characteristics, such as timing of pesticide applications.

Samples were collected and processed by following standard USGS protocols described in the National Field Manual (Wilde and others, 2009). Prior to collecting samples from the field, all field equipment was cleaned according to USGS protocols and was rinsed with native water immediately before samples were collected. In general, discrete water samples were collected for most analytes by an isokinetic, equal-width increment method (U.S. Geological Survey, 2006), where subsamples were collected at 10 increments across the stream with either a DH-81 or DH-95 sampler (Davis, 2005). The sampler had a precleaned Teflon cap and nozzle assembly that fitted a 1-liter (L) Teflon bottle (U.S. Geological Survey, 2006). Each incremental sample was placed immediately into a precleaned, acid- and methanol-rinsed Teflon churn for compositing prior to processing. When stream conditions did not meet the requirements for collection of a representative equal-width increment sample (velocity greater than 1.5 foot per second $[\mathrm{ft} / \mathrm{s}]$ ), samples were collected either by a multivertical grab (velocity less than $1.5 \mathrm{ft} / \mathrm{s}$, width greater than 10 feet), or by a grab from the centroid of flow (velocity less than $1.5 \mathrm{ft} / \mathrm{s}$, width less than 10 feet, depth less than $1 \mathrm{foot}$ ). Water was collected directly into sample bottles for unfiltered constituents and into a precleaned 1-L Teflon sample bottle for filtered constituents; samples were subsequently filtered from that bottle into sample bottles (appendix 1, table 1.3).

Much of the Northeast experienced a drought during the summer of 2016, with little or no rain for much of the QW sampling period; as a result, many streams were sampled by collecting grab samples near the end of the QW sampling period when streamflows were particularly low. In addition, however, dissolved organic carbon (DOC) samples were collected by a center grab regardless of flow conditions.

Field properties of specific conductance, $\mathrm{pH}$, dissolved oxygen, and water temperature were measured at the time of sampling with a field-calibrated multiparameter sonde (Wilde, variously dated). The measurements were made at five locations within the water-quality sampling transect. When the stream width was less than $3 \mathrm{~m}$, parameters were collected from the centroid of flow. In addition to constituents sampled in all weekly visits previously noted, samples for other waterquality constituents were collected on selected weeks during the QW sampling periods: isotopes of nitrate $\left({ }^{15} \mathrm{~N}\right.$ and $\left.{ }^{18} \mathrm{O}\right)$, organic wastewater indicators and pharmaceuticals, algal toxins, mercury (total and methyl), and ultraviolet absorbance (specific weeks when constituents were sampled are identified in appendix 1, table 1.1). Ultratrace-concentration clean-sampling procedures and equipment were used to collect samples for low-concentration total mercury and methylmercury analysis (U.S. Environmental Protection Agency, 1996; Lewis and Brigham, 2004). These were grab samples collected at about $0.3 \mathrm{~m}$ below the water surface in a Teflon bottle; five samples were collected at the 9-week sites, and three samples were collected at the 4-week sites, (table 2, in back of report; appendix 1, table 1.1).

\section{Continuous Water Temperature and Streamflow}

Digital temperature data loggers were used to continuously monitor water temperature at all stream sites. The devices recorded temperature at 1-hour intervals and were deployed during the early fall of 2015 and retrieved about a year later, in order to provide a water temperature dataset inclusive of all NESQA sampling activities. (Exceptions were several sites with USGS streamgages where continuous temperature loggers had been previously installed.) Where possible, loggers were deployed approximately 10 centimeters $(\mathrm{cm})$ above the streambed, out of direct sunlight, and attached to rebar anchored into the streambed or to stable parts of streamgage infrastructure (for example, orifice pipe). In most cases, the HOBO Water Temp Pro v2 U22 loggers were deployed (device specifications are in appendix 1, table 1.2). Guidance from the manufacturer and the U.S. Forest Service concerning deployment, calibration, and maintenance generally was followed (Dunham and others, 2005; Onset Computer Corporation, 2012). 
USGS streamgages were active at 54 NESQA sites and provided stream stage and streamflow discharge at 15-minute intervals (table 2, in back of report). Water-level loggers were deployed at the 41 sites where streamgages did not exist; these loggers recorded stream stage (and water temperature) at hourly intervals. The NESQA study used the HOBO U20001-04 digital water level loggers (specifications are in appendix 1, table 1.2). In most cases, the units were deployed during the spring of 2016, prior to the start of the QW sampling periods, and remained deployed until the fall of 2016. Guidance from the manufacturer and the USGS for deployment, calibration, and maintenance was followed (Onset Computer Corporation, 2014; Sauer and Turnipseed, 2010).

Deployment included the installation of two water-level loggers per site: one mounted in the water column to measure changes in water pressure as the water level changed, and one mounted in the air to measure barometric pressure to provide a correction factor for calculating stream stage. The loggers were mounted inside a vertical 2-inch polyvinyl chloride (PVC) pipe mounted to a bridge support or directly to a metal post driven into the streambed. The water-pressure loggers were mounted at a depth where the unit would remain continually submerged, and the barometric-pressure loggers were typically mounted in the air at the top of the pipe or post; both were programmed to record on hourly intervals for the duration of the study.

Establishing a baseline water-level was necessary immediately after installation of the water level loggers so that logger readings in water pressure could be converted to actual water level. A reference point (RP), on which changes in water level were based, was established above the pool that held the submerged water-level logger. Typically, the RP was a mark scribed on a permanently fixed structure adjacent to the attached logger, such as a bridge support or wing wall; a measurement from the RP to the water surface was the "tape down" distance. An arbitrary datum was then established that was greater than the distance between the RP and the channel bottom, and this datum would cover all low stages and ensure no negative stage values; typically, 10 feet was used. The distance from the RP to the surface of the water at time of deployment was used to establish the initial stream stage. In addition, measurements from the RP to water surface were made during at least one of the site visits by the water-quality sampling crew so that these values could be used to check the data for consistency and quality.

\section{Polar Organic Compound Integrative Samplers}

The POCISs are designed to accumulate water-soluble (polar or hydrophilic) organic compounds from surface water. These integrative samplers were deployed at all NESQA sites during the week of June 20 and retrieved during the last waterquality sampling visit during the week of August 1 (tables 2, in back of report, and 3). Four POCISs containing the sorbent Oasis HLB (Waters, Milford, Mass.) (Alvarez, 2010) were deployed in a single canister at each of the 95 sites. Oasis
HLB is considered a universal sorbent in environmental analyses and has been used to extract a wide assortment of chemical classes from water. The use of Oasis HLB in the POCIS provided a mechanism to estimate time-weighted average concentrations of target chemicals, pharmaceuticals, and pesticides. The POCIS extracts were analyzed for concentrations of pesticides and pharmaceuticals by using modified versions of the water methods for these chemical groups (Van Metre, Alvarez, and others, 2017).

Field deployment followed the guidelines provided in Alvarez (2010). Successful deployment required a stream location with sufficient depth (about $15 \mathrm{~cm}$ ) for the sampler to remain submerged during the deployment period and be protected from excessive sediment accumulation and flood debris and from vandalism. Effective anchoring systems were adopted on the basis of site-specific characteristics (for example, sandy versus rocky substrate, streamflow variability, and so forth). The POCIS was attached coincident with the temperature data logger at many sites, either on the rebar or on the orifice pipe. Field records were maintained that included the site name, date and time of deployment and retrieval, and observations of streambed substrate, streamflow conditions, and water clarity.

About 10 percent of the POCISs were accompanied by field blanks that were used to assess any accumulation of target and nontarget compounds from the air during shipment and deployment. The POCIS field-blank protocol specified that the blank canisters be open to the air at the same time and place as the field POCISs were exposed to air during deployment and retrieval. Between deployment and retrieval of the field POCISs, the POCIS blank canisters were kept sealed and stored between -20 and $0{ }^{\circ} \mathrm{C}$. All field POCISs and blank canisters were stored on ice during transport to and from the field location. After the 6-week deployment period, the POCISs were retrieved from the sites and immediately sealed in their respective canisters; the POCISs, field blanks, and log sheets were shipped to the USGS Columbia Environmental Research Center (CERC) in coolers with wet ice.

\section{Focused Studies}

Three types of focused studies were conducted at selected NESQA sites. Small-volume pesticide automated samplers were deployed at seven sites to collect daily-composited water samples for pesticide analysis. Walling tubes were deployed at 14 sites to collect integrated samples of suspended sediment. Algal productivity was evaluated at five sites with the use of nitrate, dissolved oxygen, $\mathrm{pH}$, and conductivity data that were collected continuously and chlorophyll $a$ samples that were collected monthly from April through September. 


\section{Sampling Pesticides With Small-Volume Pesticide Automated Samplers}

A small-volume pesticide autosampler (hereafter, "pesticide autosampler") was designed and built at Portland State University to collect fixed-point, small-volume samples for analysis of pesticides in water using newly developed direct aqueous injection (DAI) methods. The samplers were used in the NESQA study to help determine if increasing sampling frequency would improve the accuracy of characterizations of instream pesticide stressor conditions to which biota were subjected, in particular short-duration but acutely toxic events. Although weekly discrete samples of pesticides were collected at all sites during the QW sampling periods (with some exceptions, described in a later section, "Sample Analyses"), discrete samples might not detect short-term "spikes" in high concentrations that are potentially acutely toxic. Pesticide autosamplers were deployed at one agricultural site and six urban sites (greater than 50 percent agriculture or urban, respectively) to collect daily and weekly composite samples over the 9-week QW sampling period (table 2, in back of report).

The pesticide autosamplers were programmed to collect multiple aliquots to form daily and weekly composite samples of stream water over successive 1-week periods. An aliquot of stream water was collected every 6 hours into daily-composite vials (four aliquots per vial, with the "day" typically starting around noon) and every 12 hours into the weekly composite vial. Thus, eight vials were filled per week for seven daily samples and one weekly sample. In addition, a ninth vial containing a known pesticide spike mixture in native stream water was included to assess the potential for compound degradation during the weekly collection period. A 6-mL aliquot of a 1:1 methanol-water mixture was added, as a preservative, to each of the nine vials before deployment.

Over the 9 weeks of operation, the pesticide autosamplers were serviced each week on either Monday or Tuesday. Two units were available for each of the seven sites so that one unit could be serviced in the laboratory and exchanged in the field for the deployed unit. This arrangement minimized interruption by allowing ample time to remove and replace sample vials, charge batteries, clean tubing, and replace consumable components such as filters. Prior to deployment, each vial was labeled with the station identification number, vial number, date, and initial weight. Daily-composite samples (vials 1 through 7) were analyzed for pesticide concentrations by the EPA Office of Pesticide Programs (OPP). Sample splits of the weekly composite sample (vial 9) and the spike sample (vial 8) were analyzed for pesticide concentrations by the USGS National Water Quality Laboratory (NWQL) in Denver, Colorado, and the OPP laboratory. Analytical service request (ASR) forms (USGS) and cooler inventory forms (USGS and EPA) were included with sample shipments, and barcodes were affixed to each vial as an auxiliary data identifier and tracking method.

\section{Sampling Suspended Sediment With Walling Tube Samplers}

Suspended-sediment samples were collected from 14 sites by using time-integrating passive samplers, referred to in this report as Walling tubes (Phillips and others, 2000; Gellis and others, 2017). The sediments were analyzed for major and trace elements and radionuclides to assess sources and ages of sediment in the stream. The network of Wallingtube sites comprised 10 urban sites, 3 agricultural sites, and 1 forested site (table 2, in back of report). The Walling tube sampler was made from commercially available PVC pipe (98-millimeter [mm] inner-diameter) cut to a length of approximately $1.0 \mathrm{~m}$. The end facing upstream was affixed with a funnel that had a 4-mm stem facing outward; the downstream end of the tube was fitted with an endcap with a hole drilled in the center with a 4-mm plastic tube inserted. As water passed into the tube through the small opening in the funnel stem, the velocity decreased in the larger diameter tube, allowing suspended sediment to settle, and relatively clear water passed out of the 4-mm tube at the back. The tubes were attached to metal posts that were driven into the streambed and were oriented so that the funnel end faced into the flow. Typically, four tubes were deployed within the 150-m reach of a site, where two tubes were installed at each of two locations by placing one tube above the other on the metal posts. To ensure that samples consisted of suspended sediment and not bed sediment, the bottom tube was positioned at least $15 \mathrm{~cm}$ above the channel bed when it was deployed. If base flows were especially low at the time of deployment, the top tube was allowed to be out of water; in such cases, the top tubes would only collect sediment samples at higher flows.

Deployment of Walling tubes centered around late April, and the tubes remained deployed for approximately 20 weeks, through early October (inclusive of the 9-week QW sampling period); sediment was retrieved about every 4 weeks so that sufficient sediment could accumulate for analyses of major and trace elements and radionuclides. To collect the sediment samples, the tubes were removed from their posts, the end caps were opened, and the water and sediment were poured into a 5-gallon plastic bucket. A spray bottle filled with deionized water was used to rinse any remaining sediment from the tubes. After collecting the samples, the tubes were cleaned with a brush and deionized water, then rinsed with native water. The water-sediment mixture was stored at room temperature in the 5-gallon bucket until the sediment settled to the bottom (usually 3-7 days), then the water was siphoned off and discarded, and the remaining sediment was transferred to a sample jar and shipped on wet ice to the laboratory.

\section{Assessing Algal Productivity}

A focused investigation was conducted at five NESQA sites to assess nutrient dynamics at a high temporal resolution and to evaluate how algal productivity responds to changes in 
water quality (table 2 , in back of report). Data were collected as time-series measurements and included algal biomass, nitrate, and water-quality parameters. Three urban sites (two tier 1, one tier 3) and two agricultural sites were selected to incorporate a range of expected nutrient conditions. Sites were operated from April through September 2016 and were instrumented with an Onset photosynthetically active radiation (PAR) meter and YSI EXO2 and Sea-Bird SUNA continuous water-quality monitors, with the exception that a SUNA was not used to record nitrate at one site (Salmon River near East Hampton, Conn. [CT_SalmonHam]; although this site is categorized as tier 1 urban, the land cover is less than 4 percent urban, so the presumption was made that the stressor levels such as nitrate concentrations would be relatively low).

Continuous, discrete, and reach-level data were collected at the algal productivity sites. The following parameters were measured continuously (15-minute intervals) during the study: water temperature, dissolved oxygen, $\mathrm{pH}$, specific conductance, turbidity, fluorescent dissolved organic matter (a proxy for carbon concentration), nitrate, and PAR. Discrete samples for nutrients, suspended sediment, and DOC were collected monthly at each site over the course of the study. During each monthly visit, data also were collected along a $90-\mathrm{m}$ reach of the channel that encompassed 10 equally-spaced transects (10 $\mathrm{m}$ apart), established by using the methods described in Fitzpatrick and others (1998). Field readings for dissolved oxygen, specific conductance, $\mathrm{pH}$, and water temperature were recorded at five points along a transect across the stream channel. Macrophyte coverage was estimated at 5 locations along each of the 10 transects, and canopy density was estimated with a spherical densiometer at the center of each transect. Periphyton samples (assumed to be dominated by benthic algae) were collected at the 10 transects (right, middle, or left portions of each transect) and were composited; subsamples were extracted from the composited sample and filtered onto $0.47-\mu \mathrm{m}$ glass-fiber filters for chlorophyll $a$ and ash-free dry mass (AFDM) analysis (appendix 2.1-table 2.10) (Britton and Greeson, 1987; Arar and Collins, 1997).

\section{Ecological Surveys}

The data collected during the ecological surveys characterize aquatic biota, mercury in fish tissue, sediment contaminants, and physical habitat along a $150-\mathrm{m}$ sampling reach of each site (tables 2, in back of report, and 3). Six teams, each consisting of six USGS employees, were deployed across the region to complete the sampling at all sites during August 1-10, 2016, which was considered the shortest timeframe practical. The ecological surveys were timed to coincide with the end of the QW sampling period so that monitored waterquality conditions could be related to the biological condition. Some exceptions were made at a few sites, identified in table 2 (in back of report), where certain ecological-survey components were delayed until October 2016 because of either very low-flow or storm events during the normal ecological sampling period. Although the data collected during the ecological surveys were based on discrete samples, biological and habitat data generally represent integrative conditions over some period of time. For example, sediment chemistry is influenced by erosional processes and contaminant persistence; the species structure of aquatic biological communities depends on water-quality conditions that occur over life cycles of the organisms; and the physical habitat of a stream reach is strongly affected by many years of hydrologic events and human actions.

To ensure consistency in collecting the biological samples and conducting the physical habitat surveys, most personnel on the sampling teams were experienced in applying the methods described in USGS ecological sampling protocols and had participated in previous RSQA sampling. Algal, invertebrate, and fish community samples were collected, and habitat was assessed along a 150-m ecological assessment reach at each stream, according to the methods described in Moulton and others (2002). All field data were recorded on electronic forms by using hand-held tablet computers. Field data collected from the fish and habitat surveys, and field records for the algal and invertebrate samples destined for laboratory analysis were loaded into the USGS BioData database, the USGS repository for aquatic bioassessment data (U.S. Geological Survey, 2016).

\section{Aquatic Biota}

Algal and invertebrate communities were sampled according to standard USGS richest targeted habitat (RTH) protocols (Porter and others, 1993; Moulton and others, 2002; Hambrook and Canova, 2007). RTH samples are intended to represent the habitat features having the greatest potential diversity of organisms within a given stream reach. All NESQA sites had sampling reaches with at least one riffle zone, the assumed RTH habitat, and algal and invertebrate samples were collected from these riffles.

The algal sample was collected by scraping the periphyton biofilm from rocky substrate (for example, flat cobbles) to obtain a targeted area of $150 \mathrm{~cm}^{2}$. The substrate was scraped with a brush in a defined area and flushed into a $500-\mathrm{mL}$ bottle with native water. Typically, 11 scrapes of equal size were taken from rocks that were collected among the RTH riffles and combined into a single composited algal sample to represent the site. A total of seven aliquots were removed from the sample for various analyses. Four aliquots were filtered onto glass-fiber filters with $0.47-\mu \mathrm{m}$ pore size for analysis at the NWQL of chlorophyll $a$ and ash-free dry mass (two filters), and for backups in the event of sample loss or damage (two filters). The fifth aliquot was filtered onto a precombusted glass-fiber filter with $0.47-\mu \mathrm{m}$ pore size for analysis of carbon and nitrogen stable isotopes $\left(\delta^{13} \mathrm{C}\right.$ and $\delta^{15} \mathrm{~N}$, respectively) and $\mathrm{C}: \mathrm{N}$ ratios at the Cornell University Stable Isotope Laboratory in Ithaca, N.Y. The sixth aliquot was processed in the same manner and served as a backup in the event of sample damage or loss, or of need for additional material for analysis. The 
seventh aliquot was put into a $2-\mathrm{mL}$ vial and shipped to the Institute of Arctic and Alpine Research (INSTAAR) Diatom Laboratory at the University of Colorado Boulder for environmental DNA (eDNA) analysis. The remainder of the sample was preserved with buffered formalin at a concentration of approximately 5 percent and sent to the INSTAAR Laboratory for taxonomic identification and enumeration of diatoms.

A periphyton sample also was collected to ascertain if microcystins were present in the stream. Microcystins are a group of algal toxins produced during harmful algal blooms. The sample was collected in the same manner as the primary algal sample, except that only five scrapes were taken from rocks. The collected material was composited in a $125-\mathrm{mL}$ bottle and shipped on dry ice to the USGS Kansas Organic Geochemistry Research Laboratory (OGRL) for analysis of microcystin concentrations.

Invertebrate samples were collected from RTH riffles, using a modified Surber sampler with 500-micrometer $(\mu \mathrm{m})$ mesh net that samples a $0.25-\mathrm{m}^{2}$ area of substrate (Moulton and others, 2002). The total invertebrate sample area was targeted at 12,500 $\mathrm{cm}^{2}\left(1.25 \mathrm{~m}^{2}\right)$, the sum of a composite of five modified Surber samples each collected from a different section of riffle. The samples were sieved through a $500-\mu \mathrm{m}$ sieve, large organic and inorganic debris was removed, and then samples were transferred to a 1-L bottle and preserved with 10-percent buffered formalin. Large or rare invertebrates, such as crayfish and large mollusks, were photographed and released in accordance with collection permit procedures. Identification and enumeration of invertebrate taxa (generally to either genus or species taxonomic levels) were completed by the NWQL.

A fish-community survey was conducted at each site by using a pulsed direct current backpack electrofishing unit in conjunction with generally two staff persons netting the fish. Two electrofishing passes of the sampling reach were made. Fish were collected by two crew members using 6-mm mesh nets, and fish from the first pass were held in live wells until the completion of the second pass. All fish were identified to species and counted in the field, then released back to the stream, except for some individuals that were retained either as voucher specimens or for analysis of mercury concentrations in fish tissue.

\section{Fish Mercury Samples}

Mercury concentrations in fish tissue were analyzed at 92 of the 95 sites (table 2, in back of report), and mercury isotopes (indicators of potential $\mathrm{Hg}$ sources and environmental processing) were analyzed at 23 of the sites (table 2, in back of report). The 92 fish-tissue sites were not preselected; rather, the intent was to collect targeted fish species from every site where they were found; subsequently the targeted species were collected at 92 of the 95 sites. The 23 mercury isotope sites were selected on the basis of potential differences in mercury sources. Three general site types were selected: largely forested sites that were expected to receive $\mathrm{Hg}$ mainly from atmospheric deposition from distant sources, urban-industrial sites that were expected to have industrial (including legacy) $\mathrm{Hg}$ contamination, and urban-residential sites that were expected to have a mixture of sources. Mercury isotopes were analyzed in fish tissues and bed sediment samples collected from these 23 sites.

During the fish community survey (described previously), specimens of targeted species were retained for laboratory analysis of total mercury $(\mathrm{THg})$ concentrations and stable isotopes of carbon $\left(\delta^{13} \mathrm{C}\right)$ and nitrogen $\left(\delta^{15} \mathrm{~N}\right)$ and, at the 23 isotope sites, mercury isotopes. The primary species that were targeted were small, midtrophic level, invertivorous fishes that are widely distributed across the NESQA study area, such as blacknose dace (Rhinichthys atratulus), longnose dace (R. cataractae), creek chub (Semotilus atromaculatus), and small-sized sunfish species (Lepomis spp.). Multiple target species were collected where possible. Each sample consisted of a single-species composite of 1 to 24 (median 10) similarly sized individual whole specimens. Secondarily, predatory game fish such as brook trout (Salvelinus fontinalis), brown trout (Salmo trutta), largemouth bass (Micropterus salmoides), and large specimens of sunfish species (Lepomis spp.) were retained when encountered. Each game fish sample consisted of an individual skinless fillet. Multiple samples of one or more game fish species were collected where possible.

Field processing was minimal for both the composite samples of whole midtrophic specimens and the fillet samples of individual game fish. Specimens that were retained for mercury and stable isotope analysis were field-rinsed in deionized water or native stream water (if deionized water was not available), placed in a plastic zip-lock bag (either individually or with other conspecifics), and frozen (on dry ice or in a field freezer). Samples were delivered to the USGS New York Water Science Center (NYWSC) laboratory where they were kept frozen until further processing. At the NYWSC laboratory, specimens were thawed, rinsed thoroughly in deionized water, and measured (total length). Game fish specimens were individually weighed, and a skinless fillet was removed as described in Scudder and others (2008). The fillet was triple-rinsed in deionized water, patted dry, weighed, placed in a fresh zip-lock bag, labeled, double-bagged, and frozen. Midtrophic-level fish specimens from each site were sorted into single-species composites (containing similarly sized individuals), rinsed thoroughly in deionized water, and batch-weighed (that is, all individuals in a composited sample were weighed together). All specimens in a composite sample were placed into a fresh zip-lock bag, labeled, double-bagged, and frozen.

Samples were shipped frozen on dry ice to either the Trace Elements Research Laboratory (TERL) at Texas A\&M University in College Station, Texas (340 samples), or the USGS Mercury Research Laboratory (USGS Mercury $\mathrm{Lab}$ ) in Middleton, Wisconsin (69 samples), for analysis of THg and percent moisture. The 69 samples submitted to the USGS Mercury Lab also were analyzed for stable isotopes of THg $\left(\delta^{202} \mathrm{Hg}, \Delta^{199} \mathrm{Hg}\right.$, and $\left.\Delta^{201} \mathrm{Hg}\right)$. Upon completion of processing and analysis at the TERL and the USGS Mercury 
Lab, the remaining tissue (freeze-dried and homogenized) for each sample was sent to the Cornell University Stable Isotope Laboratory in Ithaca, N.Y., for analysis of stable isotopes of carbon $\left(d^{13} \mathrm{C}\right)$ and nitrogen $\left(d^{15} \mathrm{~N}\right)$.

\section{Sediment Samples}

At each site during the ecological survey, sediment samples were collected from the streambed and the stream banks. At 14 sites prior to the start of the ecological surveys, two streambed sediment samples were collected during the second and sixth weeks of the 9-week QW sampling period. These additional samples were identified as "temporal bed sediment samples" and, in combination with results from samples collected during the ecological survey, were to be used to evaluate how sediment chemistry varied over the 9 -week sampling period. These 14 sites are identified with " 2 " in the column labeled "Sediment Chemistry," under "Ecological Surveys," table 2 (in back of report).

Depending on the site, one or two streambed sediment samples were collected. A bulk sediment sample was collected at all sites for analysis of multiple constituents, including certain organic compounds, trace elements, organic carbon, and grain size. At 23 sites (mercury isotope sites), a second sediment sample was collected for analysis of total, methyl, and isotopic mercury. The bulk sediment sample collected at all sites and analyzed for multiple constituents was collected by following established USGS protocols (Shelton and Capel, 1994; Radtke, 2005) with several collection method variations. Four-inch (about $10-\mathrm{cm}$ ) stainless steel cylinders and stainless steel spatulas were used to collect the sediment. Multiple collections of sediment were made from depositional areas along the 150-m ecological assessment reach, targeting locations where fine-grained sediments accumulated. Depositional zones across the reach were sampled in approximate proportion to their bottom surface area. The collection method required pushing the stainless steel cylinder into the streambed to a depth of $2 \mathrm{~cm}$, then sliding the spatula under the cylinder to support the enclosed streambed core. Each streambed core was lifted gently out of the water to minimize the loss of fine material, and all cores were composited in a large plastic bucket; approximately 6 to $10 \mathrm{~L}$ of streambed material was collected for the sample. Samples were sieved in the field by using a 2-mm stainless steel sieve that rested on top of the bucket.

The bulk sediment sample was placed on ice in the field and transported to a central processing facility at the USGS office in Troy, N.Y., where samples were homogenized and split into aliquots for various analyses. Each sample was homogenized by using a kitchen mixer with a stainless steel bowl and a bread-dough-style paddle operated at low speed. Prior to the NESQA sampling, testing was done with several streambed sediment samples to determine minimum mixing time to achieve a reasonably homogeneous sample; about 30 seconds was used for initial mixing and then about 15 seconds for additional mixing between removal of aliquots. Sample aliquots were shipped chilled to various laboratories for toxicity testing and chemical analyses. Not all constituents were analyzed for all samples (appendix 1, table 1.1). Major and trace elements, organic carbon, radionuclides, and grain size were measured in samples from all sites. In samples from 72 sites, polycyclic aromatic hydrocarbons (PAHs) and other semivolatile compounds were measured. For 52 sites, among the 72 sites for which PAHs were measured, sediments were analyzed for organic wastewater indicators, organochlorine insecticides, polychlorinated biphenyls (PCBs), polybrominated diphenyl ethers (PBDEs), and current-use pesticides. Sediment from those 52 of the sites was tested by using standard whole-sediment toxicity tests with amphipod crustaceans (Hyalella azteca; 28-day exposures), midge larvae (Chironomus dilutus; 10-day exposures), and freshwater mussels (Lampsilis siliquoidea; 28-day exposures) to measure potential effects of contaminants on survival and growth. Toxicity testing was conducted at the USGS Columbia Environmental Research Center (CERC).

Aliquots for assessing the concentration of $\mathrm{THg}$ at all sites were taken from the bulk sediment samples, as described above. Sediment samples for $\mathrm{Hg}$ isotopes were collected separately at 23 sites with a cut-off $50-\mathrm{mL}$ plastic syringe to extract plugs of sediment. The plugs were collected from 6 to 10 depositional locations within and (or) near the stream reach and were placed into a wide-mouth plastic jar. Large pieces (such as twigs, leaves, and rocks) were removed from the sample by gloved fingers, and samples were immediately frozen. Samples were kept frozen and were shipped to the USGS Mercury Research Laboratory for analysis of total mercury concentration and mercury isotope analysis (the latter only in samples from the subset of 23 sites).

The bank sediment sample was collected from 5 to 10 locations along the ecological sampling reach where an exposed or eroding bank was observed on either side of the stream. At each location, sediment was collected by using a precleaned plastic trowel to scrape a vertical furrow from above the water line to the top of the exposed bank (about 1 -cm depth into the bank). The bank scrapes were composited as a single sample in a 1-L plastic jar, which was stored on wet ice and shipped to the USGS Maryland-Delaware-D.C. Water Science Center in Baltimore, Maryland, for further processing and analysis of elements and radionuclides.

\section{Physical Habitat}

The physical habitat of the reach was characterized generally by following USGS protocols (Fitzpatrick and others, 1998). The $150-\mathrm{m}$ sampling reach was segmented with 11 primary transects that were set apart every $15 \mathrm{~m}$ along the reach and with 10 secondary transects that were set approximately midway between the primary transects. Descriptive and quantitative measurements were collected across each primary transect and included geomorphic channel unit type (that is, pool, riffle, or run), stream depth, substrate size at five locations (right and left edges of water, the center of the channel, and midway between channel edges and channel midpoint), 
stream wetted width, bank height, canopy cover at mid-transect, macrophyte coverage, and the presence of bars, islands, and potential fish habitat features. Measurements made across the secondary transects were wetted width and substrate size at the five locations described above. The surface water gradient was measured over the entire $150-\mathrm{m}$ reach and indicated the average slope from the top to the bottom of the reach.

\section{Sample Analyses}

Most of the analyses of water, sediment, and invertebrate samples were conducted by the NWQL (appendix 2, tables 2.1 to 2.10), and the methods are briefly described in this section. Analytical results from the NWQL were uploaded to the Water-Quality System (QWDATA) database within the National Water Information System (NWIS) of the USGS for storage and archiving. Results of each sample in QWDATA were uniquely identified by station identification number, date, time, and medium code. Additionally, each NESQA sample was labeled with a unique barcode as a backup sampletracking identifier. Real-time data recorded by data-logging instruments and by USGS staff in the field, such as streamflow, temperature, and biological-community data, are also discussed in this section; no laboratory analyses were required to generate these data, so they were processed at the USGS water science centers that operated the instruments or made the measurements.

\section{Continuous Water Temperature and Streamflow}

Discharge data collected at active USGS streamgages (54 sites) were continuously uploaded to and made available through the USGS NWIS database. For sites where pressure transducers were installed (41 sites), the raw stage data were processed with the HOBOware graphing and analysis software (Onset Computer Corporation, Bourne, Mass.). This process included applying corrections to the stage values with barometric pressure readings and comparing tape-down measurements from the reference point to the water surface to ensure that the instruments functioned consistently and reliably while they were in service.

The water temperature data were also processed with the HOBOware software; values were checked for outliers that could indicate that the data logger was out of water, such as with very low-flow conditions. This evaluation was particularly important because of the drought conditions that existed over much of the NESQA region during the summer of 2016. The general procedure used to assess the validity of temperature readings that appeared inordinately high was to first review streamflows at the site to determine if the high temperature values corresponded to minimal stage values, then compare these temperature values with those of nearby sites to assess if the data logger was reading air rather than water temperature. Erroneous water temperature data were subsequently deleted from the data file.

\section{Chemical Analyses of Water, Sediment, and Fish}

\section{Discrete Water-Quality Samples}

Water-quality samples collected over the 9- and 4-week QW sampling periods were analyzed for nutrients, major ions, DOC/ultraviolet absorbance (UVA), and pesticides by the NWQL with the exception that pesticides were analyzed in only the last sample collected (week 9) at eight of the forested and three of the tier 1 urban sites. Samples for major ions and nutrients were analyzed by the NWQL as specified in appendix 2 (tables 2.1 and 2.2). Total phosphorus concentrations were determined by colorimetry according to EPA method 365.1 (O'Dell, 1993). Dissolved ammonia, nitrite, and orthophosphate colorimetric analyses are described by Fishman (1993). Dissolved nitrate-plus-nitrite concentrations were determined by low-level enzyme reduction colorimetry with an automated discrete analyzer, as described by Patton and Kryskalla (2011). Concentrations of dissolved cations were determined by inductively coupled plasma-atomic emission spectroscopy (Fishman, 1993), and concentrations of dissolved anions were determined by ion chromatography, as described by Fishman and Friedman (1989).

Pesticides were analyzed by direct aqueous injection (DAI) liquid chromatography tandem mass spectrometry (LC-MS/MS) (appendix 2, table 2.3; Sandstrom and others, 2015). The pesticide analytical method quantified 225 pesticides and pesticide degradates in filtered water samples. The targeted pesticides represent a broad range of chemical classes and were selected on the basis of criteria such as current-use intensity, probability of occurrence in streams and groundwater, toxicity to humans or aquatic organisms, and precision of analytical methods. The method uses direct aqueous injection of a 100-microliter $(\mu \mathrm{L})$ sample onto the LC-MS/MS without any sample preparation other than filtration. Samples were analyzed with two injection modes - positive electrospray ionization (ESI) and negative ESI - using dynamic multiple reaction monitoring (MRM) conditions and with two MRM transitions for each analyte. Recoveries for most analytes ranged from 80 to 120 percent in the water types tested, with relative standard deviations of less than 30 percent. The method detection limits ranged from 1 to 103 nanograms per liter (ng/L) for 182 analytes analyzed in the ESI positive mode and from 2 to $106 \mathrm{ng} / \mathrm{L}$ for 42 analytes analyzed in the ESI negative mode. The remaining analytes (five) had method detection limits between 100 and $250 \mathrm{ng} / \mathrm{L}$.

Human-use pharmaceuticals and organic wastewater indicator compounds were analyzed three times at the 9-week sites and once at the 4-week sites (appendix 1, table 1.1). Pharmaceutical samples were syringe-filtered into $20-\mathrm{mL}$ vials, and organic waste indicator samples were collected as whole water samples into a 1-L baked amber glass bottle. Samples were analyzed for 112 pharmaceuticals by DAI LC-MS/MS 
(appendix 2, table 2.4; Furlong and others, 2008, 2014) and for organic wastewater indicator compounds by gas chromatography mass spectrometry (GC/MS) (appendix 2, table 2.5; Zaugg and others, 2006).

Stable nitrogen $\left({ }^{15} \mathrm{~N}\right)$ and oxygen $\left({ }^{18} \mathrm{O}\right)$ isotopes of nitrate were analyzed in two of the weekly samples collected from the 9-week sites and in one of the weekly samples collected from the 4-week sites (appendix 1, table 1.1). Samples were filtered into bottles and frozen until nitrate concentration data were received and then shipped to the USGS Reston Stable Isotope Laboratory in Reston, Virginia. Isotopic analyses were done by following the method of Coplen and others (2012). Dissolved nitrate in water is converted to nitrous oxide $\left(\mathrm{N}_{2} \mathrm{O}\right)$ by denitrifying bacteria, and the nitrous oxide is analyzed for nitrogen and oxygen isotopic abundance by continuous-flow isotope-ratio mass spectrometry.

Methylmercury and THg concentrations in whole water were analyzed at the USGS Mercury Research Laboratory in Middleton, Wis., in five of the weekly samples collected from the 9-week sites and in three of the weekly samples collected from the 4-week sites. Methylmercury was analyzed by gas chromatographic separation with cold vapor atomic fluorescence spectrometry (DeWild and others, 2002); THg was analyzed by oxidation, purge and trap, and cold vapor atomic fluorescence spectrometry (method 1631, revision E; U.S. Environmental Protection Agency, 2002). The USGS Mercury Lab also analyzed DOC in samples collected weekly, as well as ultraviolet absorbance at 254 nanometers $\left(\mathrm{UVA}_{254}\right)$ in the samples collected concurrently with the mercury samples.

Weekly filtered water samples were analyzed for glyphosate by using an enzyme-linked immunosorbent assay (ELISA) at the USGS Texas Water Science Center (Mahler and others, 2017). Glyphosate also was sampled during weeks 2 (at 59 sites) and 9 (at all sites) and analyzed at the Kansas OGRL by using an online solid-phase extraction and liquid chromatography/tandem mass spectrometry (Meyer and others, 2009). These data were used to evaluate quality control of the data analyzed by the ELISA method.

Weekly discrete whole-water samples were analyzed for suspended-sediment concentrations at the USGS Kentucky Sediment Laboratory in Louisville, Kentucky. Methods for processing suspended-sediment concentrations are described in Guy (1969) and Knott and others (1993) and included use of wet-sieving filtration.

A separate water sample was collected at all sites during week 8 to survey across the region for the concentrations of microcystin in streams (appendix 1, table 1.1). These samples were processed and analyzed by the Kansas OGRL following methods outlined in Loftin and others (2016). Unfiltered samples were lysed by three sequential freeze-thaw cycles at -20 degrees Celsius and 25 degrees Celsius and then syringe filtered through 0.7 -micrometer glass fiber filters and frozen until analysis. Algal toxins were quantified by using the microcystin ELISA method with a minimum reporting level of 0.10 micrograms per liter.

\section{Pesticides From the Small-Volume Pesticide Automated Samplers}

Daily-composite samples from the pesticide autosamplers (vials 1 through 7) were analyzed for pesticide concentrations by the EPA Office of Pesticide Programs (OPP) Analytical Chemistry Laboratory in Fort Meade, Md. Sample splits of the weekly composite sample (vial 9) and the spike sample (vial 8) were analyzed for pesticide concentrations by the NWQL in Denver, Colo., as well as the OPP laboratory. The NWQL analyzed the sample for current-use pesticides (appendix 2, table 2.3) following the methods described above (Sandstrom and others, 2015). The OPP laboratory used the same direct aqueous-injection LC-MS/MS method and instrument (Agilent Model 6460) used by the NWQL with similar detection levels

\section{Polar Organic Compound Integrative Samplers}

The POCISs were processed for analysis of pesticides and pharmaceuticals by the methods described in Alvarez (2010) and in Van Metre, Alvarez, and others (2017). The CERC eluted the concentrated extract from the field and blank POCIS using methanol and concentrated the extracts to 1 milliliter $(\mathrm{mL})$. Concentrated extracts were sealed in 1 - $\mathrm{mL}$ amber glass ampules, stored at $-20^{\circ} \mathrm{C}$, and shipped to the NWQL in Denver, Colo., for analysis. At the NWQL, the extracts were transferred to analytical vials and diluted 1:100, which was required to prevent ionization suppression or enhancement of internal standards by the POCIS extracts during LC-MS/MS analysis. Laboratory blank and lab-fortified spike samples were prepared by using comparable volumes of methanol and processed with the POCIS extracts. The extracts were analyzed for concentrations of current-use pesticides (appendix 2, table 2.3) and pharmaceuticals (appendix 2, table 2.4) by LC-MS/MS by following the methods described previously for the discrete water samples.

\section{Sediment Samples}

An aliquot of each composited streambed sediment sample was analyzed for organic wastewater indicator compounds by using accelerated solvent extraction (ASE), solid-phase extraction cleanup, and GC/MS (appendix 2, table 2.6; Burkhardt and others, 2006). Sixteen parent PAHs were analyzed at RTI Laboratories (Livonia, Michigan, http://rtilab.com/), following EPA method 8270D (U.S. Environmental Protection Agency, 2014) with extraction by ASE and analysis by GC/MS with selected ion monitoring (appendix 2, table 2.7). A custom method was used for selected organohalogens in sediment (chlorinated and brominated compounds including insecticides, PCBs, and PBDEs), which extracted the sample by ASE, followed by solid-phase extraction cleanup and analysis by electron-capture negative ionization mode GC/MS with selected ion monitoring (appendix 2, table 2.8; 
reported in Mahler and others, 2009; Wagner and others, 2014). Streambed sediment was analyzed for 118 current-use pesticides at the USGS Organic Chemistry Research Laboratory (Sacramento, California) by gas chromatography-tandem mass spectrometry (GC-MS/MS) (Hladik and McWayne, 2012). Hormone compounds in sediment were analyzed with the use of GC-MS/MS (appendix 2, table 2.9; Foreman and others, 2012).

Major and trace elements were analyzed in an aliquot of the streambed sediment sample (2-mm sieve) and in an aliquot sieved to less than 63 micrometers $(<63 \mu \mathrm{m})$. Bank sediment samples and Walling tube samples also were sieved to $<63 \mu \mathrm{m}$, and the fine fraction was analyzed for major and trace elements. The samples were analyzed by AGAT Laboratories (Mississauga, Ontario, Canada, http://www.agatlabs.com/ index.cfm), using inductively coupled plasma-optical emission spectroscopy and inductively coupled plasma-mass spectrometry following dissolution in a mixture of hydrochloric, nitric, perchloric, and hydrofluoric acids (similar to the method documented in Smith and others, 2013). Aliquots of the streambed, bank, and Walling tube samples sieved to $<63 \mu \mathrm{m}$ were analyzed for radionuclides (lead-210, radium-226, cesium-137, and beryllium-7) at a USGS Sediment Radioisotope Laboratory in Menlo Park, Calif. Radionuclides were analyzed by using a high-resolution gamma spectrometer with an intrinsic germanium detector following methods described in Van Metre and others (2004).

Bed sediment samples from all sites were analyzed for THg and organic carbon at AGAT Laboratories. The mercury analysis was done by continuous flow-cold vapor-atomic fluorescence spectrometry (Hageman, 2007). Bed sediment samples that were collected from depositional zones from the 23 isotope sites were analyzed for THg by the USGS Mercury Lab by direct combustion and atomic absorption detection following EPA method 7473 (U.S. Environmental Protection Agency, 1998). Loss-on-ignition was analyzed by the USGS Mercury Lab by the method in Fishman and Friedman (1989). Bed sediment samples from 23 isotope sites also were analyzed by the USGS Mercury Lab for Hg isotopes by the same methods as described previously for fish ("Fish Mercury Samples" subsection of "Sample Collection and Processing"), except that the bed sediment samples were digested in aqua regia (3:1 $\mathrm{HCl}: \mathrm{HNO}_{3}$; Estrade and others, 2010; Lepak and others, 2015).

\section{Periphyton Samples for Assessing Algal Productivity}

Periphyton samples that were collected from five algalproductivity sites and processed in the field onto $0.47-\mu \mathrm{m}$ glass-fiber filters were shipped to the NWQL for analysis of chlorophyll $a$ and ash-free dry mass (AFDM). These samples were analyzed by using USGS method B-3520-85 and EPA method 445.0, respectively (appendix 2, table 2.10; Britton and Greeson, 1987; Arar and Collins, 1997). Ancillary data for assessing algal productivity were collected continuously by the PAR meter, YSI EXO2, and Sea-Bird SUNA continuous water-quality monitors and were processed into data records by the USGS water science centers that operated the instruments.

\section{Ecological Surveys}

\section{Aquatic Biota}

Periphyton samples for chlorophyll $a$, pheophytin $a$, and algal ash-free dry mass were collected during the ecological survey and processed in the field by filtering onto $0.47-\mu \mathrm{m}$ glass-fiber filters. The filters were analyzed by using USGS method B-3520-85 and EPA method 445.0, respectively, by the NWQL (appendix 2, table 2.10; Britton and Greeson, 1987; Arar and Collins, 1997).

Periphyton samples preserved with formalin were analyzed for diatom community composition and abundance at the INSTAAR laboratory, at the University of Colorado Boulder, following NAWQA protocols (Charles and others, 2002) with the following modification. Four replicate slides of the diatoms were made by using Battarbee chambers to obtain random distribution of cells on cover slips (Battarbee, 1973). A precount collection of voucher flora was created based on examination of 80 percent of the algal slides. The voucher flora included images of all taxa encountered, with a greater number of images for rare and previously unknown taxa. The images were sorted into operational taxonomic units (OTUs) and assigned OTU codes. Samples and their order of analysis were randomly assigned to two analysts. Ten percent of samples were reanalyzed by each analyst, and 10 percent of samples were analyzed in cross comparison. Finally, OTU codes were translated into formal scientific names following the taxonomy in the USGS BioData program and Diatoms of the United States (Spaulding and others, 2010). Voucher slides, digested material, and the voucher flora were archived at INSTAAR. The soft algae fractions of the samples were stored at INSTAAR for possible analysis at a later time.

Benthic invertebrate samples were processed by the Biological Unit of the NWQL using the quantitative fixed count method (Moulton and others, 2000). Briefly, the sample is sorted to attain a minimum of 300 organisms, which are then identified to the lowest possible taxonomic level (generally the species or genus level), which is similar to the method described in the EPA Rapid Bioassessment Protocol III (Barbour and others, 1999). Additionally, the biomass of arthropods and mollusks in the sample was estimated by measuring each of these organisms to the nearest millimeter and calculating their mass with the use of length-mass regressions for the various taxa. Quality assurance was verified in both the sorting step and the taxonomic step by a second person repeating these steps for 10 percent of the organisms. Taxonomic and enumeration results were uploaded to BioData (MacCoy, 2011). 
Fish community data were based on species identification and counts made in the field, and the data were uploaded to BioData. Although most fish were returned to the streams, some individuals were retained either as voucher specimens for identification or for tissue samples that would be analyzed for $\mathrm{Hg}$ concentrations. In some cases, photographs were taken for verification of the field identification. Voucher specimens were submitted to the Biological Survey Laboratory of the New York State Museum in Troy, N.Y., for verification of field identifications and for archiving.

\section{Sediment Toxicity Testing}

Methods used for sediment toxicity testing are described in Moran and others (2017). For sediment testing, methods in U.S. Environmental Protection Agency (2000) and in American Society for Testing and Materials International (2014b) were followed; for mussel testing, methods in American Society for Testing and Materials International (2014a) were followed. Whole sediment toxicity tests were conducted with the amphipod Hyalella azteca (28-day exposures), with the midge Chironomus dilutus (10-day exposures), and with the mussel Lampsilis siliquoidea (28-day exposures). Up to $1.8 \mathrm{~L}$ (assuming a 50/50 split of solids and liquids) of the composited streambed sediment was used for toxicity testing. Testing for each species included endpoints of survival, weight, and biomass of test organisms. Exposures were conducted at $23{ }^{\circ} \mathrm{C}$ in 300-mL beakers containing 10 test organisms fed daily and $100 \mathrm{~mL}$ of sediment with two volume additions per day of overlying water.

\section{Physical Habitat}

Data collected from habitat surveys were recorded on electronic field forms; these data were reviewed in the office by USGS staff. Any values on the field forms that were suspect (such as typographical errors) were resolved, and the data were loaded into the USGS BioData biological database (https://aquatic.biodata.usgs.gov).

\section{Quality Assurance and Quality Control}

This section primarily describes details of the quality assurance (QA) and quality control (QC) procedures for the collection of environmental water samples that were processed by the NWQL. QA/QC of project data is an iterative process that begins when samples are collected and continues through the establishment of sample records in NWIS and until the final acceptance of data as reviewed and approved or, in rare cases, rejected. This process allows for a continuous review of records by field personnel, RSQA data managers, lab analysts, team QW specialists, and team leads for both sample data (results) and metadata. Specific database scripts were developed to check sample coding logic and to generate data tables in multiple formats for data review and conformation. For sediment and fish samples, QA/QC procedures generally were simpler and included the use of replicates and standard reference materials during sample analyses in the laboratory. For samples analyzed at laboratories other than the NWQL, general QA/QC procedures may be found in the methods descriptions of publications cited previously in the "Sample Analyses" section and in the standard operating procedures maintained by the laboratories.

QA/QC procedures maintain the integrity, accuracy, and legal defensibility of results from data collection and assessment. Documented USGS QA/QC policies and procedures for environmental sampling were implemented in the NESQA study to ensure that the data can be interpreted properly and are scientifically defensible (Mueller and others, 1997; U.S. Geological Survey, 2006). QC samples were collected to identify, quantify, and document bias and variability in data that result from the sampling procedure (through field QC sampling) and laboratory procedures (through laboratory QC sampling). Field QC sampling captures bias and variability from sample collection, processing, shipping, and handling of samples. Laboratory QC sampling documents the variability of analytical methods and sample preparation in the laboratory. The QA/QC methods used by the NWQL for stream water analyses are described here. Methods used by the other laboratories that analyzed other NESQA samples may be found on the laboratory websites.

To ensure that all field crews followed consistent sample collection and processing procedures, classroom training was held for field personnel prior to the sampling period. In addition, all personnel worked through a full suite of sample collection and sample processing procedures at one of the NESQA sites prior to the start of the weekly sampling period. To minimize potential confusion in the field, all sampling scheduling, creation of analytical services request forms (ASRs) and bottle labels, and preparation of bottle kits (all sample containers needed for each site for a given visit) were handled centrally by USGS personnel who had provided similar support to previous RSQA studies.

The QC samples for constituents measured in water included field blanks, matrix spikes, and replicates (table 4; appendix 1, table 1.1). The QC plan was designed not only to meet or exceed 5 percent QC samples for inorganics and 10 percent for organics but also to ensure that QC was distributed across the region evenly and that every field crew was assigned QC samples at an appropriate interval. Field blanks were used to test if cleaning procedures would adequately remove any sampling equipment contamination introduced by samples obtained at previous sites and ensure that sample collection, processing, handling, and shipping did not result in contamination (Mueller and others, 1997; U.S. Geological Survey, 2006). Field replicates were used to test the precision of analyses at the laboratory and were prepared by dividing a single volume of water into two samples in the field. When these samples were collected from the churn, either filtered or not, two containers were filled sequentially. When grab 
Table 4. Summary counts of environmental, field blank, replicate, and spike samples of stream water from the 95 stream sites sampled in the Northeast Stream Quality Assessment of the U.S. Geological Survey National Water-Quality Assessment Project in 2016.

[Recommended percentages are from Mueller and others (1997). QA, quality assurance; KS OGRL, U.S. Geological Survey Kansas Organic Geochemistry Research Laboratory; N/A, not applicable; --, no data]

\begin{tabular}{|c|c|c|c|c|}
\hline \multirow[t]{2}{*}{ Laboratory schedule } & \multirow[t]{2}{*}{ Type of sample } & \multirow[t]{2}{*}{ Sample counts } & \multicolumn{2}{|c|}{$\begin{array}{l}\text { Ratio of QA to environmental samples } \\
\text { (percent) }\end{array}$} \\
\hline & & & Actual & Recommended \\
\hline \multirow[t]{3}{*}{ Major ions } & Environmental & 675 & N/A & N/A \\
\hline & Replicate & 30 & 4.4 & ${ }^{\mathrm{a}} 1.6$ \\
\hline & Spike & 0 & 0 & 0 \\
\hline \multirow{3}{*}{ Nutrients } & Blank & 23 & 3.3 & ${ }^{\mathrm{a}} 1.6$ \\
\hline & Replicate & 29 & 4.2 & ${ }^{\mathrm{a}} 1.6$ \\
\hline & Spike & 0 & 0 & 0 \\
\hline \multirow[t]{2}{*}{ Dissolved organic carbon } & Environmental & 682 & N/A & N/A \\
\hline & Blank & 22 & 3.2 & ${ }^{\mathrm{a}} 1.4$ \\
\hline \multirow[t]{4}{*}{ Pesticides } & Environmental & 640 & N/A & N/A \\
\hline & Blank & 24 & 3.8 & ${ }^{\mathrm{a}} 1.4$ \\
\hline & Replicate & 28 & 4.4 & ${ }^{\mathrm{a}} 1.4$ \\
\hline & Spike & 62 & 9.7 & b9.1 \\
\hline \multirow[t]{4}{*}{ Glyphosate (immunoassay) } & Environmental & 671 & N/A & N/A \\
\hline & Blank & 23 & 3.4 & -- \\
\hline & Replicate & 28 & 4.2 & -- \\
\hline & Spike & 0 & 0 & -- \\
\hline Pharmaceuticals & Environmental & 212 & N/A & N/A \\
\hline \multirow[t]{4}{*}{ Glyphosate (KS OGRL) } & Environmental & 118 & N/A & N/A \\
\hline & Blank & 6 & 5.1 & -- \\
\hline & Replicate & 7 & 5.9 & -- \\
\hline & Spike & 6 & 5.1 & -- \\
\hline \multirow[t]{4}{*}{ Mercury } & Environmental & 401 & N/A & N/A \\
\hline & Blank & 21 & 5.2 & ${ }^{\mathrm{a}} 1.4$ \\
\hline & Replicate & 23 & 5.7 & ${ }^{\mathrm{a}} 1.4$ \\
\hline & Spike & 0 & 0 & 0 \\
\hline \multirow[t]{4}{*}{ Isotopes } & Environmental & 153 & N/A & N/A \\
\hline & Blank & 0 & 0 & -- \\
\hline & Replicate & 14 & 9.2 & -- \\
\hline & Spike & 0 & 0 & -- \\
\hline
\end{tabular}

${ }^{a}$ Mueller and others (1997) recommend substituting 1 of the indicated sample types per month if many environmental samples are collected in a short period of time rather than a set of 1 per 30 (3.3 percent) or 1 per 20 (5 percent). Therefore, for the Northeast Stream Quality Assessment study, weekly samples were collected at 59 sites for 9 weeks, so the recommended percentage was computed as 1 monthly quality control sample at 59 sites, or 1.4 percent.

${ }^{\mathrm{b}} \mathrm{Recommended}$ amount is one per site. 
samples were collected, replicates were collected sequentially directly from the stream. These replicates provided a measure of the variability introduced during sample processing and analysis (Mueller and others, 1997; U.S. Geological Survey, 2006). Field and laboratory matrix spikes were used to assess the potential bias for analytes in a particular sample matrix. Bias is estimated from spiked samples by calculating the percentage of the added analyte (spike material) measured (recovered) in the sample at the laboratory (Mueller and others, 1997; U.S. Geological Survey, 2006). Recovery can be either greater than or less than 100 percent, so the bias can be either positive or negative; however, matrix interference and analyte degradation generally result in a negative bias.

Field blanks were collected once from 22 to 24 sites for each of the basic laboratory schedules (major ions, nutrients, dissolved organic carbon, pesticides, and glyphosate by immunoassay) sampled weekly (table 4). For QA/QC samples collected as part of NAWQA, Mueller and others (1997) recommend 1 field blank or replicate per every 30 (3.3 percent) or 20 (5 percent) environmental samples for the previously mentioned constituents when sampling at long-term sites; however, if many environmental samples are collected in a short period of time, as was the case in the NESQA study, it is recommended to lower the QC sample frequency to 1 per month. Therefore, for the NESQA study, the recommended percentage was computed as 1 monthly QC sample at 59 sites, or 1.4 percent. Actual field blanks represented 3.2 to 3.8 percent of the environmental samples, and split replicates for the same analyses represented 4.1 to 4.4 percent of the environmental samples, which met the frequency recommendation (table 4; Mueller and others, 1997).

No recommendation for QA/QC samples was provided for the organic compounds of emerging concern (pharmaceuticals and organic wastewater indicators) in Mueller and others (1997); therefore, we applied the same approach as used for pesticides. For pharmaceutical and organic wastewater indicator analyses, field blanks represented 4.7 percent of the environmental samples, and split replicates represented 5.2 and 4.7 percent of the environmental samples, respectively (table 4). Matrix spikes were performed on all analyses for organic compounds, with the exception of glyphosate analysis by immunoassay. The frequency of these spikes ranged from 5 to 5.2 percent, depending on the analyte (table 4).

Quality assurance included maintaining standardized sample collection and handling protocols among all field personnel as described in the National Field Manual (U.S. Geological Survey, variously dated) for water and sediment sampling and in Moulton and others (2002) for ecological sampling. All sampling and handling protocols were reviewed by field personnel involved in the NESQA study during training courses prior to field work. Additionally, several programs exist within the USGS Quality Systems Branch to help document the quality of project results. For laboratory analyses conducted by the NWQL, documented QC included doubleblind analyses of blanks for organic and inorganic constituents and provision of graphical and tabular control data for the analytical lines. Field personnel involved in the NESQA study are tested annually to verify their proficiency in collecting field data, including temperature, $\mathrm{pH}$, dissolved oxygen, alkalinity, and specific conductance.

Water-quality data from each sampling event were reviewed for completeness, precision, bias, and transcription errors when received from the laboratory as part of the QA/QC procedures. Water-quality and sediment-quality data were stored in the NWIS database. Quality-assured water-quality and sediment-quality data are available for retrieval at https://waterdata.usgs.gov/nwis/sw and through the data retrieval application at the RSQA project website (https://webapps.usgs.gov/RSQA/). The NWQL provides all QA/QC documentation for their analytical services at http://nwql.usgs.gov/Public/quality.shtml.

\section{Water-Quality Data-Management Procedures}

An important goal of data management for the NESQA study is to have the data reviewed, approved, and stored in a USGS approved database that is appropriate for the specific type of data (for example, water quality, streamflow, biological). Because NESQA sampling sites were located in multiple States, data entry and retrieval for sites in a particular State were managed by the USGS water science center (WSC) for that State. The NWIS station number that is used to identify a site (table 1, in back of report) is the master indexing and retrieval element for accessing data specific to the site. The NWIS database is the repository for most of the water-quality and streamflow data, which are the majority of the NESQA data, and is composed of separate distributed databases that are each hosted by the WSC for the State in which the site is located. Thus, the WSC responsible for managing NESQA data in NWIS depends on the State in which the NESQA site was located. Additionally, a data-management team was created to include both national RSQA staff and regional NESQA staff to facilitate the data-management process. Centralization of the data-management process was adopted to ensure consistency among the WSCs for each RSQA study and among all RSQA study areas. Nine main steps were implemented for the data-management process:

1. Sampling matrix and sample coding design

2. Electronic field form use, including barcoding

3. Sample status checks at all laboratories

4. NWIS sample record checks

5. Data transfer from laboratory to NWIS

6. Establishment of project networks

7. Sample coding and field parameter checks 
8. Data quality checks

9. Approval of data in NWIS and other databases, as appropriate

Sites selected for the NESQA study were assigned the appropriate network designations in NWIS ProjectNetworks (Dupré and others, 2013) which allows integration with similar sites across many regions and designation of the site type in NWIS. These network designations were obtained from the project planning documents and, where possible, kept consistent with other network designations that may have been used in previous regional studies. ProjectNetworks documentation was provided to local WSC personnel so they could establish their sites in NWIS ProjectNetworks.

Prior to the start of sampling, the manager of the datamanagement team prepared a matrix that would be the sampling design and coding plan for all aspects of the field activities. The sampling matrix distributed QC samples approximately equally across sites, sample teams, and time periods for optimum coverage. The matrix also served as a summary diagram for the type, frequency, and location of environmental and QC samples to be collected (appendix 1, table 1.1). A sample coding scheme was developed by the data manager that was used by the NESQA sampling teams to ensure a well-structured and manageable dataset. Additionally, training and written guidelines for sampling coding were made available to sampling teams prior to the start of sampling.

Weekly sample bottle packs were assembled at a central location by a USGS staff person designated as the field-supply manager. The bottle packs consisted of the necessary bottles, filters, preservatives, labels, and analytical service requests (ASRs) for each stream site; the packs were shipped to the local WSC at least one week prior to sampling. Centralizing the distribution of sample bottle packs helped ensure that correct sample coding, sample schedules, and timing of QC samples matched the proposed sample plan and reduced errors in the sample login process at the analytical laboratories.

Most of the NESQA sampling teams used the Personal Computer Field Form (PCFF) version 7.2 software created by the USGS, which provides electronic field forms for data collection at sampling sites. However, the use of PCFF did not preclude the use of all paper field forms when sampling; a two-page standardized form for NESQA water-quality field notes was routinely used at all sites to record basic site conditions when samples were collected and to affix bar codes that identified the samples. The bar codes were unique identifiers used to associate specific sample types with a site and the sampling event. The PCFF software streamlines the process of uploading (logging in) field data and sampling codes to NWIS by automatically generating the batch load files required by NWIS (qwsample and qwresult), thereby improving the efficiency of data flow from field and laboratory to database. The information uploaded to NWIS for each sample is stored under a unique number associated with that sample, as are later results received from the laboratory. In addition, the automation of data upload to NWIS limits the incidence of transcription errors that may occur during the manual entry of data into NWIS. Although PCFF can be used to generate the NWQL ASR documents for samples being submitted to the NWQL, the field-supply manager provided ASRs to the sampling teams each week along with the corresponding bottle sets. Some field teams did not use the PCFF; in these cases, field data were recorded on paper field forms and then transferred onto electronic digital forms in the office.

Sample shipment schedules were established prior to the start of sampling for NESQA, and generally shipments were made twice per week (appendix 1, table 1.4). Sampling teams and other WSC personnel were responsible for the shipment process. The data manager continuously tracked the shipments to verify that the shipped samples were received at each laboratory (1) within the correct holding times, (2) in the proper condition (for example, chilled samples received at the appropriate temperature of $4{ }^{\circ} \mathrm{C}$ or less), and (3) with proper documentation. The data manager worked with the laboratories to correct problems with mislabeled samples or ASRs in a timely manner and to communicate problem-resolution approaches to WSC personnel. During this process, the data manager also established the connection between the USGS Laboratory Information Management System used to transfer sample results and the NWIS database used to receive and store sample results.

During sampling and the corresponding establishment of sample records in NWIS, the data manager inspected sample coding and procedures to ensure that sample records were established properly and in a consistent manner. Sample coding or procedures were modified if found to be inaccurate or inconsistent. These modifications involved changes or corrections to sample time offsets, sample type coding, or other documentation at the laboratory or in NWIS. Modifications in sample coding or procedures related to data management or sample submittal were communicated immediately to sampling teams to ensure that appropriate adjustments were made before the next sampling.

Most of the laboratories used for NESQA sample analysis transmitted sample results through the Water Quality Data Exchange (QWDX) for automatic upload into the NWIS database. For those laboratories without the ability to use QWDX, sample results were loaded into NWIS by using manually created batch files. Batch files were created by the data manager upon receipt of electronic data from the laboratory and were loaded into the respective WSC NWIS host by the data manager or the local database administrator for the WSC. The data manager verified that the batch files of data were properly loaded into NWIS. Data files provided through email by laboratories and data not applicable to NWIS (for example, CERC toxicity data) were stored electronically in the RSQA team database rather than NWIS. These data, and data such as quality assurance sample results not publicly available through NWIS, will be made available using the ScienceBase digital data repository supported by the USGS.

After sampling was completed, the data manager inspected the NWIS sample records for completeness 
regarding field data collection, including stream measurements (streamflow, stage, sampling points, stream width, and so forth), field parameters ( $\mathrm{pH}$, air and water temperature, specific conductance, dissolved oxygen), and sample coding (sample purpose, purpose of site visit, sampling method, sampler type, and multiple QC-related sample codes). Manual checks were made for each sample, and any corrections were communicated to WSC personnel; the data manager, WSC personnel, or database administrator made any needed changes in NWIS.

National RSQA staff scientists reviewed the water-quality and sediment-quality results received from the laboratory. The water-quality data reviews included identification and review of extremes in the data (outliers); inconsistencies or unexpected results in the data; and major differences between environmental samples and replicates, detected values in blanks, and analyte recoveries in spike samples. The RSQA staff scientists communicated requests for reruns, reloads, and verification of results from the laboratory; they worked closely with the data manager to verify completeness of sample results, and a final dataset was established in NWIS as well as in a central RSQA database.

Upon completion of the data review process by the RSQA staff scientists, the data manager provided tables of the data-review results to the respective analysts for internal reviews. WSC personnel who were responsible for data quality at the WSC changed the data quality indicator (DQI) code for each individual water-quality parameter, on the basis of the results of the review, to reviewed and accepted (R) or reviewed and rejected $(\mathrm{Q})$. Any data that were rejected at the WSC level were not used in data analysis or publications. In addition to NWIS and ScienceBase, water quality, sediment, biological tissue, and ecological survey data are also made available at the RSQA mapping and data application website, which allows mapping, querying, and data downloads (https://webapps.usgs.gov/RSQA/\#!/download).

\section{Atlantic Highlands Flow-Ecology Study}

Prior to the NESQA, a study was conducted in 2014 to investigate the effects of flow alteration on the ecological condition of streams in the Northeast. Specific objectives were to (1) quantify the extent of flow alterations at USGS gaged streams across the Atlantic Highlands ecoregion; (2) identify streams where flow alterations likely have resulted in thermal regime shifts; and (3) describe how flow alterations are related to the health of aquatic ecosystems, as indicated by changes in the thermal regime, physical habitat, water chemistry, and aquatic biota. Unlike the NESQA study that was conducted as a multistressor investigation, the Atlantic Highlands flowecology study was primarily focused on flow alteration as a single stressor; thus, a different set of criteria was used for site selection that resulted in the study being more constrained in spatial extent and sampling elements.
To identify a network of sites for the study, a preliminary list of candidate streams was developed that met specific criteria: the streams were in the Atlantic Highlands ecoregion, were in primarily forested watersheds with less than 20 percent developed land, were outfitted with an active USGS streamgage, and had at least 10 years of antecedent streamflow data. A total of 190 candidate sites met these criteria. Geospatial data from the USGS GAGES-II dataset were used to identify the extent of flow alteration for the candidate sites with the use of an index of hydrologic alteration calculated from variables in the dataset (Falcone, 2011); sites then were selected to represent a gradient of hydrologic alterations from essentially unaltered (forested watersheds with no known streamflow modifications upstream from site) to highly altered (for example, immediately downstream from a large impoundment with regulated flows). Site reconnaissance was conducted during 2013 to identify a 150-m sampling reach, identify riffle habitat along the reach, evaluate access to the reach for sampling, and ascertain the absence of point sources and other human-related factors that could potentially confound verifying streamflow alteration as the primary stressor. After results from the reconnaissance were assessed, 66 gaged sites across the Atlantic Highlands ecoregion were deemed suitable for the study. Habitat was surveyed, and invertebrates and algae samples were collected at 60 "full ecology sites," but only invertebrate samples were collected at 6 "invertebrate only sites" (table 5).

All 66 sites were instrumented with a water temperature data logger that was installed in the water column in the manner described previously for the NESQA study, except in cases where water temperature was already being collected as part of the data collection routine for a site; additionally, an air temperature data logger was installed at all sites near the stream reach (typically in a tree). The data loggers were programmed to collect data at hourly intervals and were deployed in August 2013. They were removed in the fall of 2014, after ecological sampling was completed, in order to characterize at least a full year of air and water temperature regimes at each site. Also, a bed sediment sample was collected from finegrained depositional zones within the stream reach of 41 sites during the visits when temperature sensors were deployed (table 5, see footnote). Sediment from the upper $2 \mathrm{~cm}$ of depositional substrate was collected from multiple locations by using an inverted glass petri dish and small Teflon square, a technique similar to that used for NESQA sediment sampling. Sediment from multiple locations in the reach was composited in a glass bowl and mixed thoroughly. Subsamples were then removed and placed into vials and jars appropriate to each intended analysis. Frozen subsamples were submitted to the USGS Mercury Research Laboratory for analysis of total mercury, methylmercury, and loss on ignition. Chilled (wet ice) subsamples were submitted to the NWQL for analysis of PAHs and halogenated compounds, to the USGS Crustal Geophysics and Geochemistry Laboratory for analysis of major and trace elements, and to the USGS Sediment Radioisotope Laboratory for analysis of radionuclides. Methods for each of 
Table 5. Stream watersheds that were included in the Atlantic Highlands flow-ecology study, conducted by the U.S. Geological Survey as part of the National Water-Quality Assessment Project in 2014.

[Full ecology sites included habitat surveys and algal and invertebrate samples, whereas the invertebrate-only sites did not include habitat surveys and algal samples. Sites with NWIS station numbers shaded were also part of the Northeast Stream Quality Assessment site network. Latitude and longitude are referenced to the North American Datum of 1983 and shown in decimal degrees. States are abbreviated with two-letter postal codes; for example, NH is New Hampshire. NWIS, U.S. Geological Survey National Water Information System database; km², square kilometer]

\begin{tabular}{|c|c|c|c|c|c|}
\hline $\begin{array}{l}\text { NWIS } \\
\text { station } \\
\text { number }\end{array}$ & NWIS station name & Field identifier & $\begin{array}{c}\text { Latitude } \\
\text { (NWIS) }\end{array}$ & $\begin{array}{l}\text { Longitude } \\
\text { (NWIS) }\end{array}$ & $\begin{array}{c}\text { Drainage } \\
\text { area } \\
\left(\mathbf{k m}^{2}\right)\end{array}$ \\
\hline \multicolumn{6}{|c|}{ Full ecology sites } \\
\hline 01052500 & DIAMOND RIVER NEAR WENTWORTH LOCATION, NH & NH_DIAMO_WL & 44.8774 & -71.0575 & 384 \\
\hline 01054200 & WILD RIVER AT GILEAD, MAINE & ME_WILDR_GI & 44.3904 & -70.9796 & 181 \\
\hline 01055000 & SWIFT RIVER NEAR ROXBURY, MAINE & ME_SWIFT_RO & 44.6427 & -70.5888 & 251 \\
\hline 01064801 & BEARCAMP RIVER AT SOUTH TAMWORTH, NH & NH_BEARC_ST & 43.8301 & -71.2878 & 173 \\
\hline 01075000 & PEMIGEWASSET RIVER AT WOODSTOCK, NH & NH_PEMIG_WO & 43.9762 & -71.6795 & 504 \\
\hline 01082000 & CONTOOCOOK RIVER AT PETERBOROUGH, NH & NH_CONTO_PE & 42.8626 & -71.9592 & 175 \\
\hline 01133000 & EAST BRANCH PASSUMPSIC RIVER NEAR EAST HAVEN, VT & VT_EBPAS_EH & 44.6339 & -71.8976 & 138 \\
\hline 01134500 & MOOSE RIVER AT VICTORY, VT & VT_MOOSE_VI & 44.5117 & -71.8373 & 195 \\
\hline 01135150 & POPE BROOK (SITE W-3) NEAR NORTH DANVILLE, VT & VT_POPEB_ND & 44.4762 & -72.1245 & 10 \\
\hline 01135300 & SLEEPERS RIVER (SITE W-5) NEAR ST. JOHNSBURY, VT & VT_SLEEP_EF & 44.4353 & -72.0389 & 111 \\
\hline 01137500 & AMMONOOSUC RIVER AT BETHLEHEM JUNCTION, NH & NH_AMMON_BJ & 44.2687 & -71.6304 & 229 \\
\hline 01139800 & EAST ORANGE BRANCH AT EAST ORANGE, VT & VT_EORAN_EO ${ }^{1}$ & 44.0928 & -72.3357 & 23 \\
\hline 01153550 & WILLIAMS RIVER NEAR ROCKINGHAM, VT & VT_WILLI_RO ${ }^{1}$ & 43.1917 & -72.4851 & 290 \\
\hline 01154000 & SAXTONS RIVER AT SAXTONS RIVER, VT & VT_SAXTO_SA ${ }^{1}$ & 43.1376 & -72.4881 & 187 \\
\hline 01155500 & WEST RIVER AT JAMAICA, VT & VT_WESTR_JA & 43.1090 & -72.7754 & 460 \\
\hline 01158600 & OTTER BROOK BELOW OTTER BROOK DAM, NEAR KEENE, NH & NH_OTTER_KE ${ }^{1}$ & 42.9459 & -72.2368 & 122 \\
\hline 01164000 & MILLERS RIVER AT SOUTH ROYALSTON, MA & MA_MILLE_SR & 42.6298 & -72.1504 & 492 \\
\hline 01166500 & MILLERS RIVER AT ERVING, MA & MA_MILLE_ER ${ }^{1}$ & 42.5976 & -72.4381 & 966 \\
\hline 01169000 & NORTH RIVER AT SHATTUCKVILLE, MA & MA_NORTH_SH ${ }^{1}$ & 42.6384 & -72.7251 & 231 \\
\hline 01169900 & SOUTH RIVER NEAR CONWAY, MA & MA_SOUTH_CO ${ }^{1}$ & 42.5420 & -72.6937 & 62 \\
\hline 01170100 & GREEN RIVER NEAR COLRAIN, MA & MA_GREEN_CO ${ }^{1}$ & 42.7034 & -72.6706 & 107 \\
\hline 01174565 & WEST BRANCH SWIFT RIVER NEAR SHUTESBURY, MA & MA_WBSWI_SH ${ }^{1}$ & 42.4551 & -72.3818 & 33 \\
\hline 01175500 & SWIFT RIVER AT WEST WARE, MA & MA_SWIFT_WW' & 42.2679 & -72.3326 & 490 \\
\hline 01179500 & WESTFIELD RIVER AT KNIGHTVILLE, MA & MA_WESTF_KN ${ }^{1}$ & 42.2879 & -72.8643 & 422 \\
\hline 01180500 & MIDDLE B WESTFIELD RIVER AT GOSS HEIGHTS, MA & MA_MBWES_GH ${ }^{1}$ & 42.2587 & -72.8726 & 137 \\
\hline 01181000 & WEST BRANCH WESTFIELD RIVER AT HUNTINGTON, MA & MA_WBWES_HU ${ }^{1}$ & 42.2373 & -72.8957 & 244 \\
\hline 01185500 & WEST BRANCH FARMINGTON RIVER NEAR NEW BOSTON, MA & MA_WBFAR_NB & 42.0793 & -73.0729 & 237 \\
\hline 01186000 & WEST BRANCH FARMINGTON RIVER AT RIVERTON, CT & CT_WBFAR_RI ${ }^{1}$ & 41.9629 & -73.0176 & 334 \\
\hline 01187300 & HUBBARD RIVER NEAR WEST HARTLAND, CT & CT_HUBBA_WA & 42.0373 & -72.9390 & 54 \\
\hline 01202501 & SHEPAUG RIVER AT PETERS DAM AT WOODVILLE, CT & CT_SHEPA_WO ${ }^{1}$ & 41.7193 & -73.2929 & 100 \\
\hline 01315500 & HUDSON RIVER AT NORTH CREEK, NY & NY_HUDSO_NC ${ }^{1}$ & 43.7009 & -73.9835 & 2,059 \\
\hline 01321000 & SACANDAGA RIVER NEAR HOPE, NY & NY_SACAN_HO ${ }^{1}$ & 43.3528 & -74.2704 & 1,264 \\
\hline 01333000 & GREEN RIVER AT WILLIAMSTOWN, MA & MA_GREEN_WI ${ }^{1}$ & 42.7090 & -73.1968 & 112 \\
\hline 01336000 & MOHAWK RIVER BELOW DELTA DAM NEAR ROME, NY & NY_MOHAW_RO ${ }^{1}$ & 43.2645 & -75.4363 & 386 \\
\hline 01343060 & WEST CANADA CREEK NEAR WILMURT, NY & NY_WCANA_WI ${ }^{1}$ & 43.3662 & -74.9577 & 610 \\
\hline
\end{tabular}


Table 5. Stream watersheds that were included in the Atlantic Highlands flow-ecology study, conducted by the U.S. Geological Survey as part of the National Water-Quality Assessment Project in 2014.-Continued

[Full ecology sites included habitat surveys and algal and invertebrate samples, whereas the invertebrate-only sites did not include habitat surveys and algal samples. Sites with NWIS station numbers shaded were also part of the Northeast Stream Quality Assessment site network. Latitude and longitude are referenced to the North American Datum of 1983 and shown in decimal degrees. States are abbreviated with two-letter postal codes; for example, NH is New Hampshire. NWIS, U.S. Geological Survey National Water Information System database; km², square kilometer]

\begin{tabular}{|c|c|c|c|c|c|}
\hline $\begin{array}{l}\text { NWIS } \\
\text { station } \\
\text { number }\end{array}$ & NWIS station name & Field identifier & $\begin{array}{l}\text { Latitude } \\
\text { (NWIS) }\end{array}$ & $\begin{array}{c}\text { Longitude } \\
\text { (NWIS) }\end{array}$ & $\begin{array}{c}\text { Drainage } \\
\text { area } \\
\left(\mathbf{k m}^{2}\right)\end{array}$ \\
\hline \multicolumn{6}{|c|}{ Full ecology sites-Continued } \\
\hline 01349810 & WEST KILL NEAR WEST KILL, NY & NY_WESTK_WK ${ }^{1}$ & 42.2304 & -74.3929 & 74 \\
\hline 01350080 & MANOR KILL AT WEST CONESVILLE NEAR GILBOA, NY & NY_MANOR_GI ${ }^{1}$ & 42.3770 & -74.4129 & 84 \\
\hline 01350140 & MINE KILL NEAR NORTH BLENHEIM, NY & NY_MINEK_NB ${ }^{1}$ & 42.4290 & -74.4729 & 44 \\
\hline 013621955 & BIRCH CREEK AT BIG INDIAN, NY & NY_BIRCH_BI ${ }^{1}$ & 42.1090 & -74.4518 & 33 \\
\hline 01362200 & ESOPUS CREEK AT ALLABEN, NY & NY_ESOPU_AL ${ }^{1}$ & 42.1170 & -74.3801 & 169 \\
\hline 01363382 & BUSH KILL BLW MALTBY HOLLOW BK AT WEST SHOKAN, NY & NY_BUSHK_WS ${ }^{1}$ & 41.9656 & -74.2929 & 44 \\
\hline 01374581 & W BR CROTON RIVER BELOW DAM NEAR KENT CLIFFS, NY & NY_WBCRO_KC ${ }^{1}$ & 41.4498 & -73.7365 & 58 \\
\hline 01384500 & RINGWOOD CREEK NEAR WANAQUE, NJ & NJ_RINGW_WA ${ }^{1}$ & 41.1275 & -74.2656 & 44 \\
\hline 01413398 & BUSH KILL NEAR ARKVILLE, NY & NY_BUSHK_AR ${ }^{1}$ & 42.1509 & -74.6013 & 121 \\
\hline 01413408 & DRY BROOK AT ARKVILLE, NY & NY_DRYBR_AR ${ }^{1}$ & 42.1468 & -74.6232 & 213 \\
\hline 01414000 & PLATTE KILL AT DUNRAVEN, NY & NY_PLATT_DU ${ }^{1}$ & 42.1331 & -74.6954 & 90 \\
\hline 01414500 & MILL BROOK NEAR DUNRAVEN, NY & NY_MILLB_DU ${ }^{1}$ & 42.1062 & -74.7304 & 64 \\
\hline 01427510 & DELAWARE RIVER AT CALLICOON, NY & NY_DELAW_CA & 41.7568 & -75.0574 & 4,725 \\
\hline 01434017 & EAST BR NEVERSINK RIVER NR CLARYVILLE, NY & NY_EBNEV_CL ${ }^{1}$ & 41.9254 & -74.5402 & 60 \\
\hline 01434025 & BISCUIT BK ABOVE PIGEON BK AT FROST VALLEY, NY & NY_BISCU_FV & 41.9954 & -74.5010 & 10 \\
\hline 01434498 & WEST BRANCH NEVERSINK R AT CLARYVILLE, NY & NY_WBNEV_CL ${ }^{1}$ & 41.9204 & -74.5746 & 88 \\
\hline 01435000 & NEVERSINK RIVER NEAR CLARYVILLE, NY & NY_NEVER_CL & 41.8901 & -74.5899 & 172 \\
\hline 01436000 & NEVERSINK RIVER AT NEVERSINK, NY & NY_NEVER_NE & 41.8201 & -74.6354 & 241 \\
\hline 01436690 & NEVERSINK RIVER AT BRIDGEVILLE, NY & NY_NEVER_BR & 41.6381 & -74.6169 & 443 \\
\hline 01439500 & BUSH KILL AT SHOEMAKERS, PA & PA_BUSHK_SH & 41.0882 & -75.0377 & 306 \\
\hline 01440400 & BRODHEAD CREEK NEAR ANALOMINK, PA & PA_BRODH_AN ${ }^{1}$ & 41.0848 & -75.2146 & 175 \\
\hline 01447800 & $\begin{array}{l}\text { LEHIGH RIVER BLW FRANCIS E WALTER RES NR WHITE } \\
\text { HAVEN, PA }\end{array}$ & PA_LEHIG_WH ${ }^{1}$ & 41.1048 & -75.7321 & 753 \\
\hline 04287000 & DOG RIVER AT NORTHFIELD FALLS, VT & VT_DOGRI_NF ${ }^{1}$ & 44.1828 & -72.6404 & 199 \\
\hline 04288230 & RANCH BROOK AT RANCH CAMP, NEAR STOWE, VT & VT_RANCH_ST ${ }^{1}$ & 44.5039 & -72.7818 & 10 \\
\hline 04289000 & LITTLE RIVER NEAR WATERBURY, VT & VT_LITTL_WA ${ }^{1}$ & 44.3701 & -72.7693 & 287 \\
\hline \multicolumn{6}{|c|}{ Invertebrate-only sites } \\
\hline 01053500 & ANDROSCOGGIN RIVER AT ERROL, NH & NH_ANDRO_ER & 44.7826 & -71.1287 & 2,702 \\
\hline 01054000 & ANDROSCOGGIN RIVER NEAR GORHAM, NH & NH_ANDRO_GO & 44.4358 & -71.1902 & 3,528 \\
\hline 01055500 & NEZINSCOT RIVER AT TURNER CENTER, MAINE & ME_NEZIN_TC & 44.2695 & -70.2296 & 440 \\
\hline 01144000 & WHITE RIVER AT WEST HARTFORD, VT & VT_WHITE_WH' ${ }^{1}$ & 43.7142 & -72.4181 & 1,790 \\
\hline 04285500 & NORTH BRANCH WINOOSKI RIVER AT WRIGHTSVILLE, VT & VT_NBWIN_WR ${ }^{1}$ & 44.2995 & -72.5787 & 182 \\
\hline 04288000 & MAD RIVER NEAR MORETOWN, VT & VT_MADRI_MO & 44.2773 & -72.7426 & 364 \\
\hline
\end{tabular}

\footnotetext{
${ }^{1} \mathrm{~A}$ bed sediment sample was collected at these sites.
} 
these analyses are described previously (section "Chemical Analyses of Water, Sediment, and Fish").

Each of the 66 sites was visited twice during the summer of 2014 for data collection, generally using methods described for the NESQA study. The first visit, in August, consisted of the following at the 60 full ecology sites: measuring specific conductance, dissolved oxygen, $\mathrm{pH}$, and water temperature with YSI field meters; collecting a grab water sample from a well-mixed portion of the stream (one sample per site, two additional QA samples at three sites); collecting invertebrate and periphyton samples from riffle habitats; and measuring the water-surface gradient along the reach. During the August 2014 visit at the six invertebrate only sites, an invertebrate sample was collected from riffle habitats, but no other sampling was done. The second site visit was made in late September or early October and consisted of the following: removing the temperature data loggers from the reach and downloading the data at all sites, and conducting a habitat assessment at the full ecology sites.

Water samples were kept on wet ice in the field and transferred to a refrigerator at the NYWSC laboratory. Samples were then shipped overnight to the NWQL and analyzed at the NWQL for major ions, dissolved organic carbon, acidneutralizing capacity, filtered aluminum, and inorganic monomeric aluminum, according to methods detailed in Lawrence and others (1995). Algal samples were preserved in formalin as previously described and were shipped to INSTAAR and analyzed as previously described. Invertebrate samples were field-processed and preserved as previously described. The samples were analyzed by a contract laboratory (Rhithron Associates, Inc., Missoula, Montana), and the data were uploaded into the USGS BioData biological database (https://aquatic.biodata.usgs.gov).

\section{Summary}

This report summarizes the design and methods used during an intensive regional study to assess stream quality in the northeastern United States: the Northeast Stream Quality Assessment. Ninety-five wadeable stream sites were selected throughout five Level III ecoregions to determine the occurrence and levels of multiple stressors and to assess the conditions of aquatic biological communities. Water quality was measured during a 4- or 9-week period from June to August 2016, followed by an ecological survey to assess the biological communities (algal, invertebrates, fish), contaminants in sediment, mercury in fish tissue, and the physical habitat of the stream, as well as other aspects of stream condition such as indicators of harmful algal blooms. Multiple parameters covering a wide variety of potential stressors to aquatic life were measured during the Northeast Stream Quality Assessment and included both discrete and continuous data collected over the course of the assessment at all 95 sites and in special focused studies conducted at subsets of sites.
Procedures are described that were used for sample analyses, quality assurance and quality control, and data management. The overall goal of the assessment is to improve our understanding of multiple water-quality stressors that affect wadeable streams throughout the region by evaluating relations between these stressors and indicators of stream health.

A related study on which the Northeast Stream Quality Assessment was built was the Atlantic Highlands flow-ecology study conducted during 2014 that investigated 66 streams and focused on effects of flow alteration on stream ecosystems. The design of the Atlantic Highlands flow-ecology study, which consisted of a subset of the many variables considered in the 2016 multistressor assessment, is also summarized here.

\section{References Cited}

Alvarez, D.A., 2010, Guidelines for the use of the semipermeable membrane device (SPMD) and the polar organic chemical integrative sampler (POCIS) in environmental monitoring studies: U.S. Geological Survey Techniques and Methods, book 1, chap. D4, 28 p. [Also available at https://pubs.er.usgs.gov/publication/tm1D4.]

American Society for Testing and Materials International, 2014a, Standard guide for conducting laboratory toxicity tests with freshwater mussels, Report ASTM E2455-06 (2013) in Annual Book of American Society for Testing and Materials International Standards Volume 11.06: West Conshohocken, Pa., American Society for Testing and Materials International, accessed May 6, 2015, at http://www.astm.org/Standards/E2455.htm.

American Society for Testing and Materials International, 2014b, Standard test method for measuring the toxicity of sediment associated contaminants with freshwater invertebrates, Report ASTM E1706-05 (2010) in Annual Book of American Society for Testing and Materials International Standards Volume 11.06: West Conshohocken, Pa., American Society for Testing and Materials International, accessed May 6, 2015, at http://www.astm.org/Standards/ E1706.htm.

Arar, E.J., and Collins, G.B., 1997, U.S. Environmental Protection Agency method 445.0 - In vitro determination of chlorophyll $a$ and pheophytin $a$ in marine and freshwater algae by fluorescence (rev. 1.2, September 1997): Cincinnati, Ohio, U.S. Environmental Protection Agency, National Exposure Research Laboratory, Office of Research and Development, $22 \mathrm{p}$.

Barbour, M.T., Gerritsen, J., Snyder, B.D., and Stribling, J.B., 1999, Rapid bioassessment protocols for use in streams and wadeable rivers-Periphyton, benthic macroinvertebrates, and fish (2d ed.): U.S. Environmental Protection Agency report 841-B-99-002, variously paged. 
Battarbee, R.W., 1973, A new method for the estimation of absolute microfossil numbers, with reference especially to diatoms: Limnology and Oceanography, v. 18, no. 4, p. 647-653. [Also available at https://doi.org/10.4319/ lo.1973.18.4.0647.]

Britton, L.J., and Greeson, P.E., eds., 1987, Gravimetric method for biomass, in Methods for collection and analysis of aquatic biological and microbiological samples: U.S. Geological Survey Techniques of Water-Resources Investigations, book 5, chap. A4, p. 139-140. [Also available at https://pubs.er.usgs.gov/publication/twri05A4.]

Burkhardt, M.R., Zaugg, S.D., Smith, S.G., and ReVello, R.C., 2006, Determination of wastewater compounds in sediment and soil by pressurized solvent extraction, solid-phase extraction, and capillary-column gas chromatography/ mass spectrometry: U.S. Geological Survey Techniques and Methods, book 5, chap. B2, 33 p. [Also available at https://pubs.er.usgs.gov/publication/tm5B2.]

Charles, D.F., Knowles, C., and Davis, R.S., 2002, Protocols for the analysis of algal samples collected as part of the U.S. Geological Survey National Water-Quality Assessment Program: Philadelphia, The Academy of Natural Sciences Report 02-06, 124 p. [Also available at http://diatom.ansp.org/nawqa/Protocols.aspx.

Coles, J.F., McMahon, G., Bell, A.H., Brown, L.R., Fitzpatrick, F.A., Eikenberry-Scudder, B.C., Woodside, M.D., Cuffney, T.F., Bryant, W.L., Cappiella, K., Fraley-McNeal, L., and Stack, W.P., 2012, Effects of urban development on stream ecosystems in nine metropolitan study areas across the United States: U.S. Geological Survey Circular 1373, 138 p. [Also available at https://pubs.er.usgs.gov/publication/cir1373.]

Coplen, T.B., Qi, H., Révész, K., Casciotti, K., and Hannon, J.E., 2012, Determination of the $\delta^{15} \mathrm{~N}$ and $\delta^{18} \mathrm{O}$ of nitrate in water; RSIL lab code 2900, chap. 17 of Stable isotope-ratio methods, sec. C of Révész, Kinga, and Coplen, T.B. eds., Methods of the Reston Stable Isotope Laboratory [slightly revised from ver. 1.0 released in 2006]: U.S. Geological Survey Techniques and Methods, book 10, chap. 17C, 35 p. [Also available at http://pubs.usgs.gov/tm/2006/tm10c17/.

Davis, B.E., 2005, A guide to the proper selection and use of federally approved sediment and water-quality samplers: U.S. Geological Survey Open-File Report 2005-1087, 20 p. [Also available at https://pubs.er.usgs.gov/publication/ ofr20051087.]

DeWild, J.F., Olsen, M.L., and Olund, S.D., 2002, Determination of methyl mercury by aqueous phase ethylation, followed by gas chromatographic separation with cold vapor atomic fluorescence detection: U.S. Geological Survey Open-File Report 01-445, 14 p. [Also available at https://pubs.er.usgs.gov/publication/ofr2001445.]
Dunham, J., Chandler, G., Rieman, B., and Martin, D., 2005, Measuring stream temperature with digital data loggers-A user's guide: U.S. Department of Agriculture, Forest Service, Rocky Mountain Research Station, General Technical Report RMRS-GTR-150WWW, 16 p., accessed December 19, 2014, at http://www.fs.fed.us/rm/pubs/rmrs_gtr150.pdf.

Dupré, D.H., Scott, J.C., Clark, M.L., Canova, M.G., and Stoker, Y.E., 2013, User's manual for the National Water Information System of the U.S. Geological Survey-WaterQuality System, Version 5.0: U.S. Geological Survey OpenFile Report 2013-1054, 730 p., accessed November 2, 2016, at http://pubs.usgs.gov/of/2013/1054. [Supersedes USGS Open-File Report 2006-1145.]

Estrade, N., Carignan, J., Sonke, J.E., and Donard, O.F.X., 2010, Measuring Hg isotopes in bio-geo-environmental reference materials: Geostandards and Geoanalytical Research, v. 34, no. 1, p. 79-93. [Also available at https://doi.org/10.1111/j.1751-908X.2009.00040.x.]

Falcone, J.A., 2011, GAGES-II-Geospatial attributes of gages for evaluating streamflow: U.S. Geological Survey digital spatial dataset, accessed April 2015 at http://water.usgs.gov/GIS/metadata/usgswrd/XML/ gagesII_Sept2011.xml.

Fishman, M.J., ed., 1993, Methods of analysis by the U.S. Geological Survey National Water Quality LaboratoryDetermination of inorganic and organic constituents in water and fluvial sediments: U.S. Geological Survey Open-File Report 93-125, 217 p. [Also available at https://pubs.er.usgs.gov/publication/ofr93125.]

Fishman, M.J., and Friedman, L.C., 1989, Methods for determination of inorganic substances in water and fluvial sediments: U.S. Geological Survey Techniques of WaterResources Investigations, book 5, chap. A1, 545 p. [Also available at https://pubs.er.usgs.gov/publication/twri05A1.]

Fitzpatrick, F.A., White, I.R., D’Arconte, P.J., Meador, M.R., Maupin, M.A., and Gurtz, M.E., 1998, Revised methods for characterizing stream habitat in the National Water-Quality Assessment Program: U.S. Geological Survey WaterResources Investigations Report 98-4052, 67 p. [Also available at https://pubs.er.usgs.gov/publication/wri984052.]

Foreman, W.T., Gray, J.L., ReVello, R.C., Lindley, C.E., Losche, S.A., and Barber, L.B., 2012, Determination of steroid hormones and related compounds in filtered and unfiltered water by solid-phase extraction, derivatization, and gas chromatography with tandem mass spectrometry: U.S. Geological Survey Techniques and Methods, book 5, chap. B9, 118 p. [Also available at https://pubs.er.usgs.gov/ publication/tm5B9.] 
Fry, J., Xian, G., Jin, S., Dewitz, J., Homer, C., Yang, L., Barnes, C., Herold, N., and Wickham, J., 2011, Completion of the 2006 National Land Cover Database for the conterminous United States: Photogrammetric Engineering and Remote Sensing, v. 77, no. 9, p. 858-864.

Furlong, E.T., Noriega, M.C., Kanagy, C.J., Kanagy, L.K., Coffey, L.J., and Burkhardt, M.R., 2014, Determination of human-use pharmaceuticals in filtered water by direct aqueous injection-High-performance liquid chromatography/ tandem mass spectrometry: U.S. Geological Survey Techniques and Methods, book 5, chap. B10, 49 p., accessed April 3, 2015, at http://dx.doi.org/10.3133/tm5B10.

Furlong, E.T., Werner, S.L., Anderson, B.D., and Cahill, J.D., 2008, Determination of human-health pharmaceuticals in filtered water by chemically modified styrene-divinylbenzene resin-based solid-phase extraction and highperformance liquid chromatography/mass spectrometry: U.S. Geological Survey Techniques and Methods, book 5, chap. B5, 56 p. [Also available at https://pubs.er.usgs.gov/ publication/tm5B5.]

Gellis, A.C., Fuller, C.C., and Van Metre, P.C., 2017, Sources and ages of fine-grained sediment to streams using fallout radionuclides in the midwestern United States: Journal of Environmental Quality, v. 194, p. 73-85, accessed June 2017 at http://dx.doi.org/10.1016/j.jenvman.2016.06.018.

Gregory, M.B., and Calhoun, D.L., 2006, Physical, chemical, and biological responses of streams to increasing watershed urbanization in the Piedmont ecoregion of Georgia and Alabama, 2003: U.S. Geological Survey Scientific Investigations Report 2006-5101-B, 104 p. [Also available at https://pubs.er.usgs.gov/publication/sir20065101B.]

Guy, H.P., 1969, Laboratory theory and methods for sediment analysis: U.S. Geological Survey Techniques of WaterResources Investigations, book 5, chap. C1, 58 p. [Also available at https://pubs.er.usgs.gov/publication/twri05C1.]

Hageman, P.L., 2007, Determination of mercury in aqueous and geologic materials by continuous flow-cold vaporatomic fluorescence spectrometry (CVAFS): U.S. Geological Survey Techniques and Methods, book 5, chap. D2, 6 p. [Also available at https://pubs.er.usgs.gov/publication/ tm5D2.]

Hambrook, J.A., and Canova, M.G., 2007, Algal biomass indicators (ver. 1.0, August 2007): U.S. Geological Survey Techniques of Water-Resources Investigations, book 9, chap. A7, sec. 7.4, 86 p., accessed December 2, 2014, at http://pubs.water.usgs.gov/twri9A/.
Herlihy, A.T., Hughes, R.M., and Sifneos, R.C., 2006, National clusters of fish species assemblages in the conterminous United States and their relationship to existing landscape classification schemes, in Hughes, R.M., Wang, L., and Seelbach, P.W., eds, Landscape influences on stream habitats and biological assemblages-Proceedings of the Symposium on Influences of Landscape on Stream Habitat and Biological Communities held in Madison, Wisconsin, USA, 25-26 August 2004: Bethesda, Md., American Fisheries Society, p. 87-112.

Herlihy, A.T., Paulsen, S.G., Sickle, J.V., Stoddard, J.L., Hawkins, C.P., and Yuan, L.L., 2008, Striving for consistency in a national assessment-The challenges of applying a reference-condition approach at a continental scale: Journal of the North American Benthological Society, v. 27, no. 4, p. 860-877. [Also available at https://doi.org/10.1899/08-081.1.]

Hladik, M.L., and McWayne, M.M., 2012, Methods of analysis-Determination of pesticides in sediment using gas chromatography/mass spectrometry: U.S. Geological Survey Techniques and Methods, book 5, chap. C3, 18 p. [Also available at $\mathrm{http}: / /$ pubs.usgs.gov/tm/tm5c3.]

Homer, C.G., Dewitz, J.A., Yang, L., Jin, S., Danielson, P., Xian, G., Coulston, J., Herold, N.D., Wickham, J.D., and Megown, K., 2015, Completion of the 2011 National Land Cover Database for the conterminous United StatesRepresenting a decade of land cover change information: Photogrammetric Engineering and Remote Sensing, v. 81, no. 5, p. 345-354.

Klemm, D.J., Blocksom, K.A., Fulk, F.A., Herlihy, A.T., Hughes, R.M., Kaufmann, P.R., Peck, D.V., Stoddard, J.L., Thoeny, W.T., Griffith, M.B., and Davis, W.S., 2003, Development and evaluation of a macroinvertebrate biotic integrity index (MBII) for regionally assessing Mid-Atlantic Highlands streams: Environmental Management, v. 31, no. 5, p. 656-669. [Also available at https://doi.org/10.1007/ s00267-002-2945-7.]

Knott, J.M., Glysson, G.D., Malo, B.A., and Schroeder, L.J., 1993, Quality assurance plan for the collection and processing of sediment data by the U.S. Geological Survey, Water Resources Division: U.S. Geological Survey Open-File Report 92-499, 18 p., accessed November 17, 2010, at http://pubs.er.usgs.gov/pubs/ofr/ofr92499.

Lawrence, G.B., Lincoln, T.A., Horan-Ross, D.A., Olson, M.L., and Waldron, L.A., 1995, Analytical methods of the U.S. Geological Survey's New York District Water-Analysis Laboratory: U.S. Geological Survey Open-File Report 1995-0416, 78 p. [Also available at https://pubs.er.usgs.gov/publication/ofr95416.] 
Lenat, D.R., and Crawford, J.K., 1994, Effects of land use on water quality and aquatic biota of three North Carolina Piedmont streams: Hydrobiologia, v. 294, no. 3, p. 185-199. [Also available at https://doi.org/10.1007/BF00021291.]

Lepak, R.F., Yin, R., Krabbenhoft, D.P., Ogorek, J.M., DeWild, J.F., Holsen, T.M., and Hurley, J.P., 2015, Use of stable isotope signatures to determine mercury sources in the Great Lakes: Environmental Science \& Technology Letters, v. 2, no. 12, p. 335-341. [Also available at https://doi.org/10.1021/acs.estlett.5b00277].

Lewis, M.E., and Brigham, M.E., 2004, Low level mercury: U.S. Geological Survey Techniques of Water-Resources Investigations, book 9, chap. A5, section 5.6.4.B, 26 p., accessed March 16, 2007, at http://water.usgs.gov/owq/ FieldManual/chapter5/pdf/5.6.4.B_v1.0.pdf.

Loftin, K.A., Clark, J.M., Journey, C.A., Kolpin, D.W., Van Metre, P.C., Carlisle, D., and Bradley, P.M., 2016, Spatial and temporal variation in microcystin occurrence in wadeable streams in the southeastern United States: Environmental Toxicology and Chemistry, v. 35, no. 9, p. 2281-2287, accessed November 2016 at https://doi.org/10.1002/ etc. 3391 .

MacCoy, D.M., 2011, BioData-A national aquatic bioassessment database: U.S. Geological Survey Fact Sheet 2011-3112, 4 p. [Also available at https://pubs.er.usgs.gov/ publication/fs20113112.]

Mahler, B.J., Van Metre, P.C., Burley, T.E., Loftin, K.A., Meter, M.T., and Nowell, L.H., 2017, Similarities and differences in occurrence and temporal fluctuations in glyphosate and atrazine in small Midwestern streams (USA) during the 2013 growing season: Science of the Total Environment, v. 579, p. 149-158, accessed May 2017 at https://doi.org/10.1016/j.scitotenv.2016.10.236.

Mahler, B.J., Van Metre, P.C., Wilson, J.T., Musgrove, M., Zaugg, S.D., and Burkhardt, M.R., 2009, Fipronil and its degradates in indoor and outdoor dust: Environmental Science \& Technology, v. 43, no. 15, p. 5665-5670. [Also available at https://doi.org/10.1021/es901292a.]

Meyer, M.T., Loftin, K.A., Lee, E.A., Hinshaw, G.H., Dietze, J.E., and Scribner, E.A., 2009., Determination of glyphosate, its degradation product aminomethylphosphonic acid, and glufosinate, in water by isotope dilution and online solid-phase extraction and liquid chromatography/tandem mass spectrometry: U.S. Geological Survey Techniques and Methods, book 5, chap. A10, 32 p. [Also available at https://pubs.er.usgs.gov/publication/tm5A10.]
Moran, P.W., Nowell, L.H., Kemble, N.E., Mahler, B.J., Waite, I.R., and Van Metre, P.C., 2017, Influence of sediment chemistry and sediment toxicity on macroinvertebrate communities across 99 wadable streams of the Midwestern USA: Science of the Total Environment, v. 599-600, p. 1469-1478, accessed December 2017 at https://doi.org/10.1016/j.scitotenv.2017.05.035.

Moulton, S.R., II, Carter, J.L., Grotheer, S.A., Cuffney, T.F., and Short, T.M., 2000, Methods of analysis by the U.S. Geological Survey National Water Quality Laboratory-Processing, taxonomy, and quality control of benthic macroinvertebrate samples: U.S. Geological Survey Open-File Report 00-212, 49 p. [Also available at https://pubs.er.usgs.gov/publication/ofr00212.]

Moulton, S.R., II, Kennen, J.G., Goldstein, R.M., and Hambrook, J.A., 2002, Revised protocols for sampling algal, invertebrate, and fish communities as part of the National Water-Quality Assessment Program: U.S. Geological Survey Open-File Report 02-150, 75 p., accessed April 3, 2015, at http://pubs.usgs.gov/of/2002/ofr-02-150/.

Mueller, D.K., Martin, J.D., and Lopes, T.J., 1997, Quality control design for surface-water sampling in the National Water-Quality Assessment Program: U.S. Geological Survey Open-File Report 97-223, 17 p. [Also available at https://pubs.er.usgs.gov/publication/ofr97223.]

Nagy, R.C., Lockaby, B.G., Helms, B., Kalin, L., and Stoeckel, D., 2011, Water resources and land use and cover in a humid region-The southeastern United States: Journal of Environmental Quality, v. 40, no. 3, p. 867-878, accessed April 3, 2015, at https://doi.org/10.2134/jeq2010.0365.

O’Dell, J.W., 1993, EPA Method 365.1-Determination of phosphorus by semi-automated colorimetry (rev. 2.0, August 1993): Cincinnati, Ohio, U.S. Environmental Protection Agency, Office of Research and Development, 17 p.

Omernik, J.M., and Griffith, G.E., 2014, Ecoregions of the conterminous United States-Evolution of a hierarchical spatial framework: Environmental Management, v. 54, no. 6, p. 1249-1266. [Also available at https://doi.org/10.1007/s00267-014-0364-1.]

Onset Computer Corporation, 2012, HOBO Water Temp Pro v2 (U22-001) manual-User manual 10366-G: Onset Computer Corporation user manual, 3 p., accessed December 13, 2013, at http:/www.onsetcomp.com/files/ manual_pdfs/10366-G-MAN-U22-001.pdf.

Onset Computer Corporation, 2014, HOBO U20 Water Level Logger (U20-001-0x and U20-001-0x-Ti) manual: Onset Computer Corporation user manual, 7 p., accessed December 31, 2104, at http:/www.onsetcomp.com/files/ manual_pdfs/12315-F-MAN-U20.pdf. 
Patton, C.J., and Kryskalla, J.R., 2011, Colorimetric determination of nitrate plus nitrite in water by enzymatic reduction, automated discrete analyzer methods: U.S. Geological Survey Techniques and Methods, book 5, chap. B8, 34 p. [Also available at https://pubs.er.usgs.gov/publication/ tm5B8.]

Phillips, J.M., Russell, M.A., and Walling, D.E., 2000, Timeintegrated sampling of fluvial suspended sediment-A simple methodology for small catchments: Hydrological Processes, v. 14, no. 14, p. 2589-2602. [Also available at https://doi.org/10.1002/1099-1085(20001015)14:14<2589:: AID-HYP94>3.0.CO;2-D.]

Porter, S.D., Cuffney, T.F., Gurtz, M.E., and Meador, M.R., 1993, Methods for collecting algal samples as part of the National Water Quality Assessment Program: U.S. Geological Survey Open-File Report 93-409, 39 p. [Also available at https://pubs.er.usgs.gov/publication/ofr93409.]

Radtke, D.B., 2005, Bottom-material samples: U.S. Geological Survey Techniques of Water-Resources Investigations, book 9, chap. A8, variously paged, accessed February 22, 2007, at http://pubs.water.usgs.gov/twri9A8/.

Sandstrom, M.W., Kanagy, L.K., Anderson, C.A., and Kanagy, C.J., 2015, Determination of pesticides and pesticide degradates in filtered water by direct aqueousinjection liquid chromatography-tandem mass spectrometry: U.S. Geological Survey Techniques and Methods, book 5, chap B11, 54 p., accessed December 8, 2015, at http://dx.doi.org/10.3133/tm5B11.

Sandstrom, M.W., and Wilde, F.D., 2014, Syringe-filter procedure for processing samples for analysis of organic compounds by DAI LC-MS/MS: U.S. Geological Survey Techniques of Water-Resources Investigations, book 9, chap. A5, sec. 2.2B, 10 p., accessed February 6, 2015, at http://water.usgs.gov/owq/FieldManual/chapter5/ pdf/5.2.2.B.pdf.

Sauer, V.B., and Turnipseed, D.P., 2010, Stage measurement at gaging stations: U.S. Geological Survey Techniques and Methods, book 3, chap. A7, 45 p. [Also available at https://pubs.er.usgs.gov/publication/tm3A7.]

Scudder, B.C., Chasar, L.C., DeWeese, R., Brigham, M.E., Wentz, D.A., and Brumbaugh, W.G., 2008, Procedures for collecting and processing aquatic invertebrates and fish for analysis of mercury as part of the National WaterQuality Assessment Program: U.S. Geological Survey Open-File Report 2008-1208, 34 p. [Also available at https://pubs.er.usgs.gov/publication/ofr20081208.]
Shelton, L.R., and Capel, P.D., 1994, Guidelines for collecting and processing samples of stream bed sediment for analysis of trace elements and organic contaminants for the National Water-Quality Assessment Program: U.S. Geological Survey Open-File Report 94-458, 20 p. [Also available at https://pubs.er.usgs.gov/publication/ofr94458.]

Smith, D.B., Cannon, W.F., Woodruff, L.G., Solano, Federico, Kilburn, J.E., and Fey, D.L., 2013, Geochemical and mineralogical data for soils of the conterminous United States: U.S. Geological Survey Data Series 801, 19 p., accessed July 2015 at http://pubs.usgs.gov/ds/801/.

Spaulding, S.A., Lubinski, D.J., and Potapova, M., 2010, Diatoms of the United States: University of Colorado website, accessed March 2017 at http://westerndiatoms.colorado.edu.

U.S. Environmental Protection Agency, 1996, Method 1669Sampling ambient water for trace metals at EPA water quality criteria levels: Washington, D.C., U.S. Environmental Protection Agency, Office of Water, Engineering and Analysis Division, 37 p., accessed March 12, 2011, at http://www.epa.gov/waterscience/methods/method/ inorganics/1669.pdf.

U.S. Environmental Protection Agency, 1998, Method 7473 (SW-846) - Mercury in solids and solutions by thermal decomposition, amalgamation, and atomic absorption spectrophotometry: Washington, D.C., U.S. Environmental Protection Agency, accessed April 2016 at http:/www.epa.gov/ osw/hazard/testmethods/sw846/pdfs/7473.pdf.

U.S. Environmental Protection Agency, 2000, Methods for measuring the toxicity and bioaccumulation of sedimentassociated contaminants with freshwater invertebrates (2d ed., March 2000): Duluth, Minn., and Washington, D.C., U.S. Environmental Protection Agency Office of Research and Development and Office of Water, report EPA 600/R-99/064, 192 p., accessed July 2016 at http://water.epa.gov/polwaste/sediments/cs/upload/ freshmanual.pdf.

U.S. Environmental Protection Agency, 2002, Method 1631, Revision E-Mercury in water by oxidation, purge and trap, and cold vapor atomic fluorescence spectrometry: Washington, D.C., U.S. Environmental Protection Agency, Office of Water, report EPA-821-R-02-019, 38 p.

U.S. Environmental Protection Agency, 2006, Wadeable streams assessment-A collaborative survey of the Nation's streams: Washington, D.C., U.S. Environmental Protection Agency, Office of Research and Development and Office of Water, report EPA 841-B-06-002, 98 p.

U.S. Environmental Protection Agency, 2014, Method 8270D - Semivolatile organic compounds by gas chromatography/mass spectrometry: U.S. Environmental Protection Agency SW-846 test method, 71 p. 
U.S. Environmental Protection Agency and U.S. Geological Survey, 2012, National Hydrography Dataset Plus-NHDPlus, version 2, edition 2.10: U.S. Environmental Protection Agency and U.S. Geological Survey geospatial data, accessed January 21, 2015, at http://www.horizon-systems.com/NHDPlus/index.php.

U.S. Geological Survey, 2006, Collection of water samples (ver. 2.0, September 2006): U.S. Geological Survey Techniques of Water-Resources Investigations, book 9, chap. A4, 166 p. plus apps., accessed October 24, 2014, at http://pubs.water.usgs.gov/twri9A4/.

U.S. Geological Survey, 2012, The Midwest Stream Quality Assessment: U.S. Geological Survey Fact Sheet 2012-3124, 2 p. [Also available at https://pubs.usgs.gov/fs/2012/3124.]

U.S. Geological Survey, 2014, NLCD 2011 land coverNational Geospatial Data Asset (NGDA) land use land cover (2011 ed., amended October 10, 2014): U.S. Geological Survey dataset, accessed February 2015 at http://www.mrlc.gov.

U.S. Geological Survey, 2016, BioData-Aquatic bioassessment data for the Nation: U.S. Geological Survey database, accessed January 2017 at http://dx.doi.org/doi:10.5066/ F77W698B.

U.S. Geological Survey, variously dated, National field manual for the collection of water-quality data: U.S. Geological Survey Techniques of Water-Resources Investigations, book 9, chaps. A1-A9, variously paged, accessed October 19, 2009, at http://pubs.usgs.gov/twri/.

Van Metre, P.C., Alvarez, D., Mahler, B.J., Nowell, L.H., Sandstrom, M.W., and Moran, P.W., 2017, Complex mixtures of pesticides in Midwest US streams indicated by POCIS time integrating samplers: Environmental Pollution, v. 220, p. 431-440, accessed February 2017 at https://doi.org/10.1016/j.envpol.2016.09.085.

Van Metre, P.C., Egler, A.L., and May, J., 2017, The California Stream Quality Assessment: U.S. Geological Survey Fact Sheet 2017-3014, 2 p. [Also available at https://doi.org/10.3133/fs20173014.]

Van Metre, P.C., and Journey, C.A., 2014, The Southeast Stream Quality Assessment: U.S. Geological Survey Fact Sheet 2014-3023, 2 p. [Also available at https://doi.org/10.3133/fs20143023.]
Van Metre, P.C., Morace, J.L., and Sheibley, R., 2015, The Pacific Northwest Stream Quality Assessment: U.S. Geological Survey Fact Sheet 2015-3020, 2 p. [Also available at https://doi.org/10.3133/fs20153020.]

Van Metre, P.C., Wilson, J.T., Fuller, C.C., Callender, Edward, and Mahler, B.J., 2004, Collection, analysis, and age dating of sediment cores from 56 U.S. lakes and reservoirs sampled by the U.S. Geological Survey, 1992-2001: U.S. Geological Survey Scientific Investigations Report 20045184, 180 p. [Also available at https://pubs.er.usgs.gov/ publication/sir20045184.]

Wagner, R.J., Moran, P.W., Zaugg, S.D., Sevigny, J.M., and Pope, J.M., 2016, Contaminants of emerging concern in the lower Stillaguamish River Basin, Washington, 2008-11 (ver. 2.0, June 2016): U.S. Geological Survey OpenFile Report 2014-1028, 14 p., accessed August 2016 at https://pubs.er.usgs.gov/publication/ofr20141028.

Waite, I.R., Herlihy, A.T., Larsen, D.P., and Klemm, D.J., 2000 , Comparing strengths of geographic and nongeographic classifications of stream benthic macroinvertebrates in the Mid-Atlantic Highlands, USA: Journal of the North American Benthological Society, v. 19, no. 3, p. 429-441. [Also available at https://doi.org/10.2307/1468105.]

Wiken, E., Jiménez Nava, F., and Griffith, G., 2011, North American terrestrial ecoregions-Level III: Montreal, Canada, Commission for Environmental Cooperation, 149 p.

Wilde, F.D., ed., variously dated, Field measurements, in National field manual for the collection of water-quality data: U.S. Geological Survey Techniques of Water-Resources Investigations, book 9 , chap. A6, variously paged, accessed December 3, 2014, at http://pubs.water.usgs.gov/twri9A.

Wilde, F.D., and Radtke, D.B., Gibs, Jacob, and Iwatsubo, R.T., eds., 2009, Processing of water samples (ver. 2.2, September 2004 with updates through 2009): U.S. Geological Survey Techniques of Water-Resources Investigations, book 9, chap. A5, accessed October 24, 2014, at http://pubs.water.usgs.gov/twri9A5/.

Zaugg, S.D., Smith, S.G., and Schroeder, M.P., 2006, Determination of wastewater compounds in whole water by continuous liquid-liquid extraction and capillary-column gas chromatography/mass spectrometry: U.S. Geological Survey Techniques and Methods, book 5, chap. B4, 30 p. [Also available at https://pubs.er.usgs.gov/publication/tm5B4.] 

Tables 1-2 


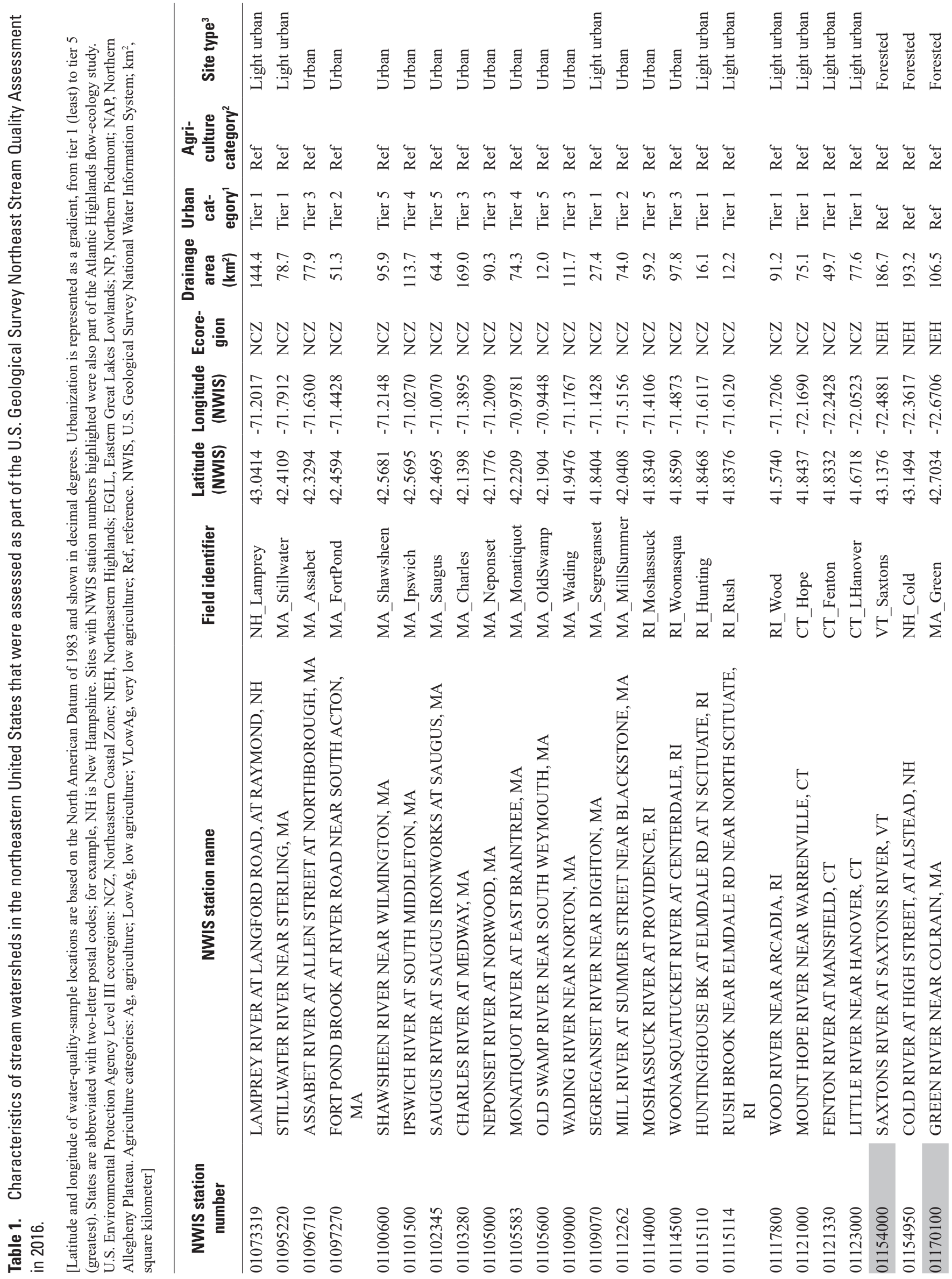




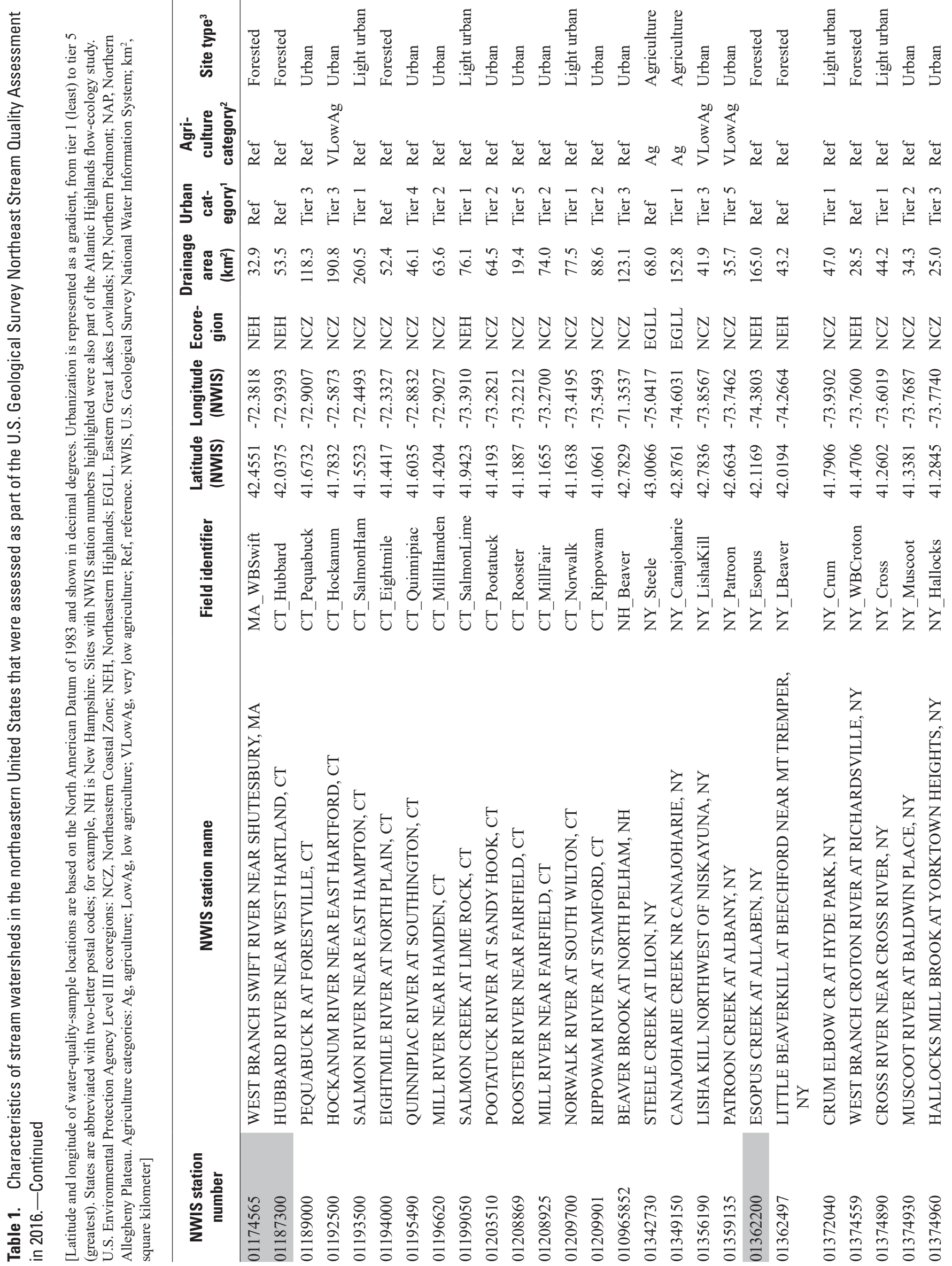




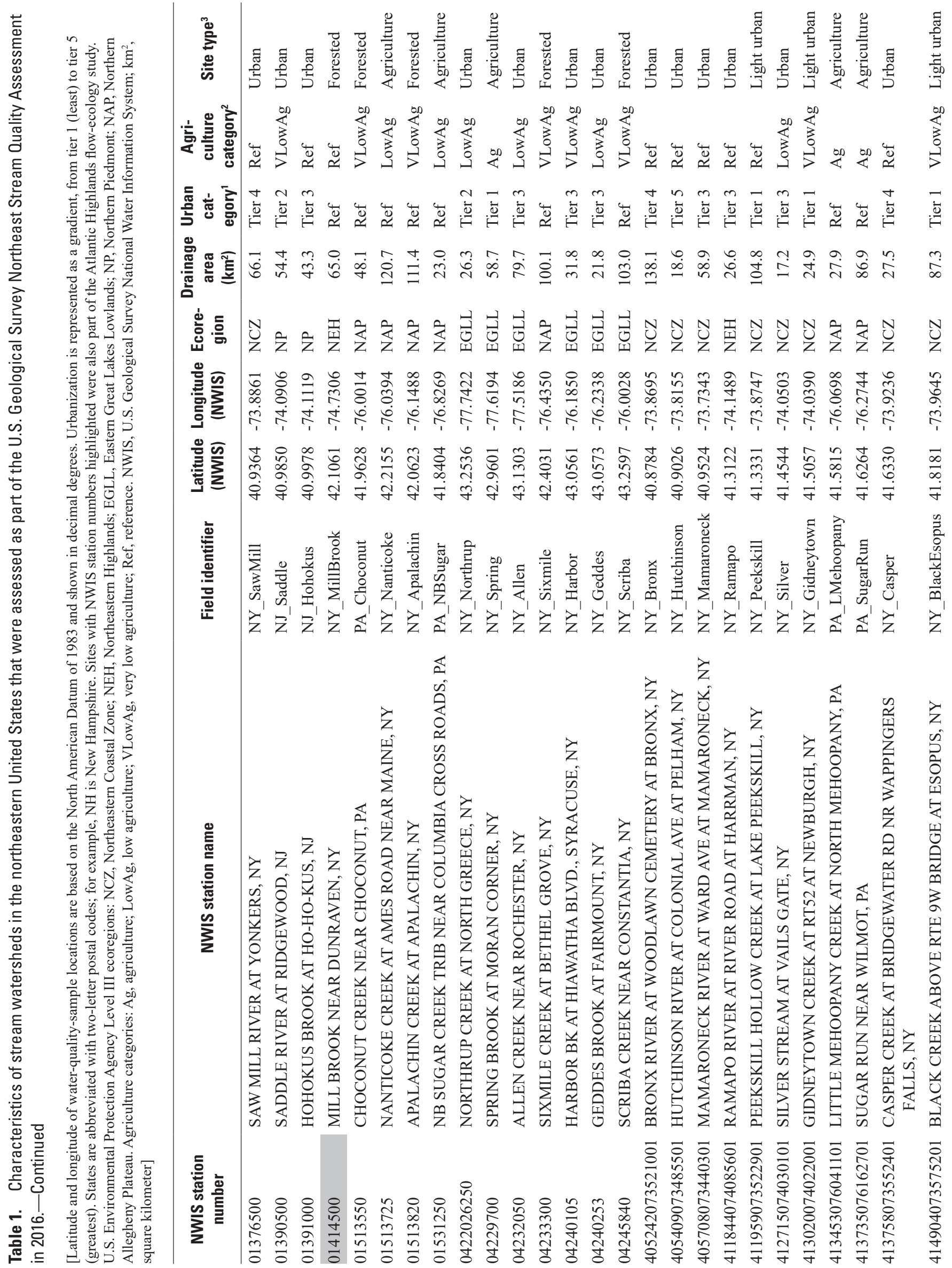




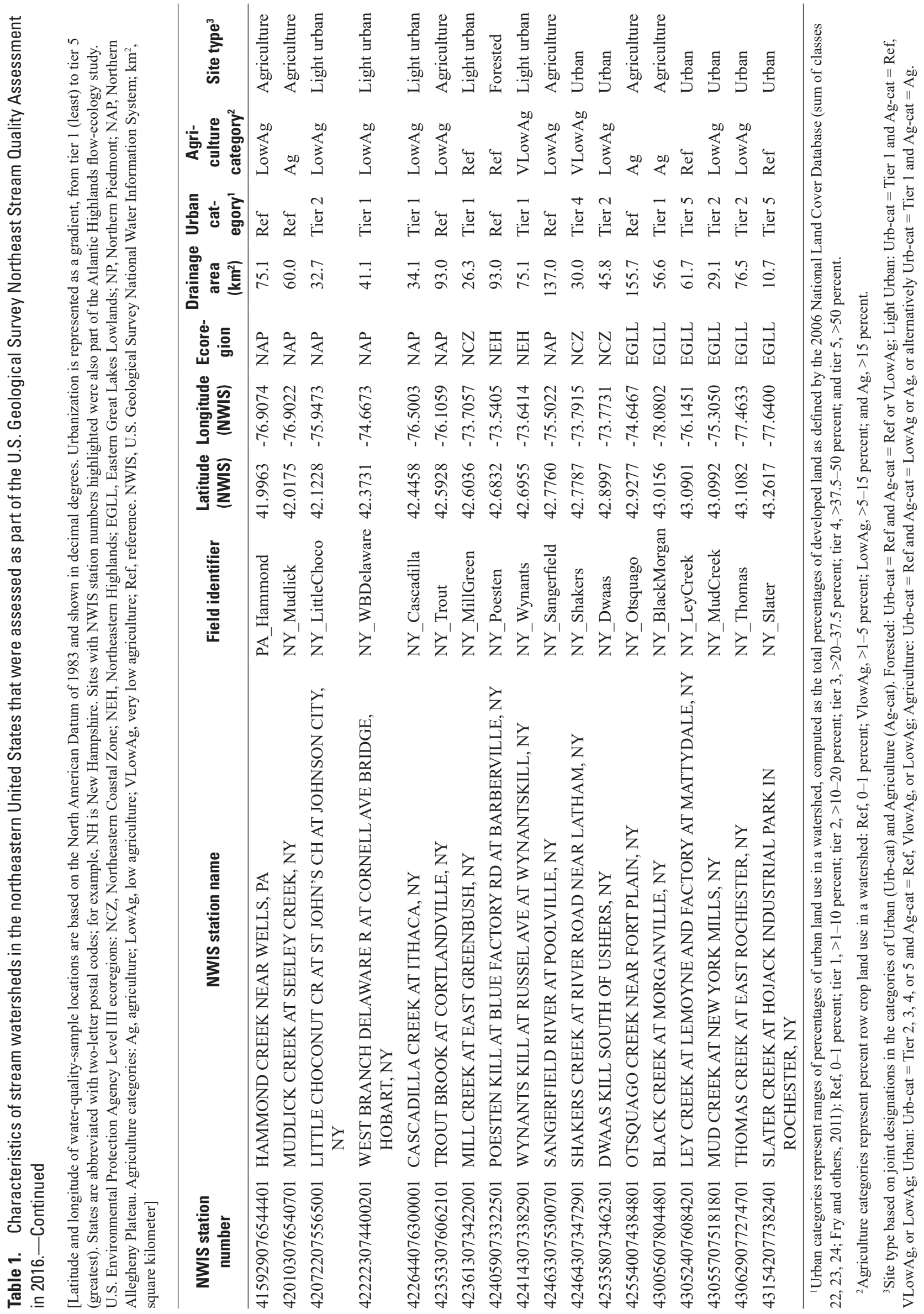


Table 2. Summary of data collected at each of the Northeast Stream Quality Assessment sites in 2016.

[Parameters are categorized by the Northeast Stream Quality Assessment study-design components: comprehensive stream water data, focused studies, and ecological surveys. Numerical values in the table indicate the number of times samples were collected/analyzed for each parameter type. "I" indicates an integrated sample. "C" indicates a continuous sample. "D" indicates sites where components of ecological surveys were delayed from August until October 2016. "1iso" indicates that mercury isotopes were also analyzed. States are abbreviated with two-letter postal codes; for example, NH is New Hampshire. POCIS, polar organic chemical integrative sampler; PAH, polycyclic aromatic hydrocarbon; --, not sampled.]

\begin{tabular}{|c|c|c|c|c|c|c|c|c|c|c|c|c|c|c|c|c|c|c|c|c|c|c|c|c|c|}
\hline Site infor & ion & & & & & m & e & ns & 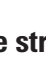 & n & $\mathrm{v}$ & e & & & & & & $\begin{array}{l}\text { Cuse } \\
\text { tudie }\end{array}$ & & & Ecc & . & 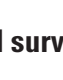 & eys & \\
\hline Field ide & $\begin{array}{l}\text { Primary } \\
\text { land-use } \\
\text { type }\end{array}$ & 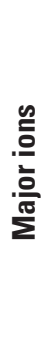 & 冚 & 递 & 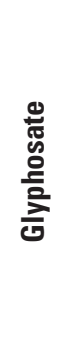 & 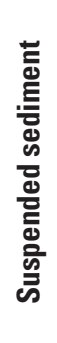 & 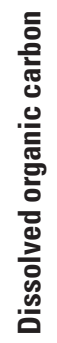 & 를 & 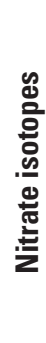 & 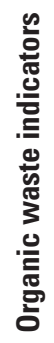 & 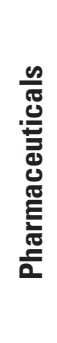 & 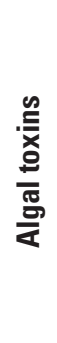 & $\begin{array}{l}\text { 옴 } \\
\text { 옹 }\end{array}$ & 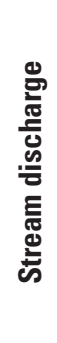 & 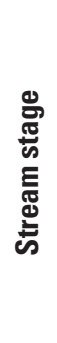 & 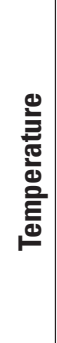 & 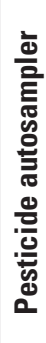 & 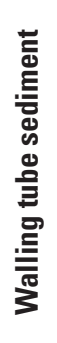 & 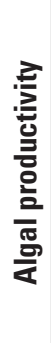 & 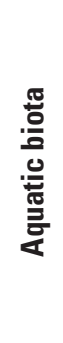 & 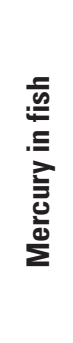 & 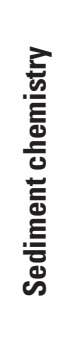 & 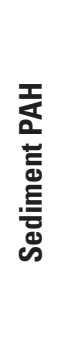 & 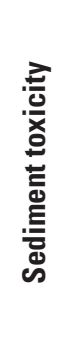 & 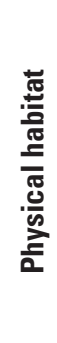 \\
\hline NH_Lamprey & Light urban & 4 & 4 & 4 & 4 & 4 & 4 & 3 & 1 & 3 & 3 & 1 & I & $\mathrm{C}$ & -- & $\mathrm{C}$ & -- & -- & -- & 1 & 1 & 1 & 1 & -- & 1 \\
\hline MA_Stillwater & Light urban & 4 & 4 & 4 & 4 & 4 & 4 & 3 & 1 & 3 & 3 & 1 & I & $\mathrm{C}$ & -- & $\mathrm{C}$ & -- & -- & -- & 1 & 1iso & 1 & 1 & -- & 1 \\
\hline MA_Assabet & Urban & 9 & 9 & 9 & 9 & 9 & 9 & 4 & 1 & 3 & 3 & 1 & I & -- & $\mathrm{C}$ & $\mathrm{C}$ & -- & I & -- & 1 & 1 & 1 & 1 & 1 & 1 \\
\hline MA_Saugus & Urban & 9 & 9 & 9 & 9 & 9 & 9 & 4 & 1 & 3 & 3 & 1 & I & $\mathrm{C}$ & -- & $\mathrm{C}$ & -- & -- & -- & 1 & -- & 1 & 1 & 1 & 1 \\
\hline MA_Charles & Urban & 9 & 9 & 9 & 9 & 9 & 9 & 4 & 1 & 3 & 3 & 1 & I & $\mathrm{C}$ & -- & $\mathrm{C}$ & I & I & -- & 1 & 1iso & 2 & 1 & 1 & 1 \\
\hline MA_Neponset & Urban & 9 & 9 & 9 & 9 & 9 & 9 & 4 & 1 & 3 & 3 & 1 & I & $\mathrm{C}$ & -- & $\mathrm{C}$ & -- & I & -- & 1 & 1iso & 2 & 1 & 1 & 1 \\
\hline MA_Monatiquot & Urban & 9 & 9 & 9 & 9 & 9 & 9 & 4 & 1 & 3 & 3 & 1 & I & $\mathrm{C}$ & -- & $\mathrm{C}$ & -- & -- & -- & 1 & 1 & 2 & 1 & 1 & 1 \\
\hline MA_OldSwamp & Urban & 9 & 9 & 9 & 9 & 9 & 9 & 4 & 1 & 3 & 3 & 1 & I & $\mathrm{C}$ & -- & $\mathrm{C}$ & -- & -- & -- & 1 & 1iso & 1 & 1 & 1 & 1 \\
\hline MA_Wading & Urban & 9 & 9 & 9 & 9 & 9 & 9 & 4 & 1 & 3 & 3 & 1 & I & $\mathrm{C}$ & -- & $\mathrm{C}$ & -- & -- & -- & 1 & 1 & 1 & 1 & 1 & 1 \\
\hline MA_Segreganset & Light urban & 2 & 2 & 2 & 2 & 2 & 2 & 1 & 1 & 0 & 0 & 0 & I & $\mathrm{C}$ & -- & $\mathrm{C}$ & -- & -- & -- & -- & -- & -- & -- & -- & -- \\
\hline MA_MillSummer & Urban & 9 & 9 & 9 & 9 & 9 & 9 & 4 & 1 & 3 & 3 & 1 & I & -- & $\mathrm{C}$ & $\mathrm{C}$ & -- & -- & -- & 1 & 1 & 1 & 1 & 1 & 1 \\
\hline CT_Fenton & Light urban & 4 & 4 & 4 & 4 & 4 & 4 & 3 & 1 & 3 & 3 & 1 & I & $\mathrm{C}$ & -- & $\mathrm{C}$ & -- & -- & -- & 1 & 1 & 1 & 1 & -- & 1 \\
\hline CT_LHanover & Light urban & 4 & 4 & 4 & 4 & 4 & 4 & 3 & 1 & 3 & 3 & 1 & I & $\mathrm{C}$ & -- & $\mathrm{C}$ & -- & -- & -- & 1 & 1 & 1 & -- & -- & 1 \\
\hline VT_Saxtons & Forested & 4 & 4 & 4 & 4 & 4 & 4 & 3 & 1 & 3 & 3 & 1 & I & $\mathrm{C}$ & -- & $\mathrm{C}$ & -- & -- & -- & 1 & 1iso & 1 & -- & -- & 1 \\
\hline NH_Cold & Forested & 4 & 4 & 4 & 4 & 4 & 4 & 3 & 1 & 3 & 3 & 1 & I & $\mathrm{C}$ & -- & $\mathrm{C}$ & -- & -- & -- & 1 & 1 & 1 & -- & -- & 1 \\
\hline MA_Green & Forested & 4 & 4 & 4 & 4 & 4 & 4 & 3 & 1 & 3 & 3 & 1 & I & $\mathrm{C}$ & -- & $\mathrm{C}$ & -- & -- & -- & $1 \mathrm{D}$ & 1 & 1 & 1 & 1 & 1 \\
\hline MA_WBSwift & Forested & 4 & 4 & 4 & 4 & 4 & 4 & 3 & 1 & 3 & 3 & 1 & I & $\mathrm{C}$ & -- & $\mathrm{C}$ & -- & -- & -- & 1 & 1iso & 1 & -- & -- & 1 \\
\hline CT_Hubbard & Forested & 4 & 4 & 4 & 4 & 4 & 4 & 3 & 1 & 3 & 3 & 1 & I & $\mathrm{C}$ & -- & $\mathrm{C}$ & -- & -- & -- & 1 & 1iso & 1 & -- & -- & 1 \\
\hline CT_Pequabuck & Urban & 9 & 9 & 9 & 9 & 9 & 9 & 4 & 1 & 3 & 3 & 1 & I & $\mathrm{C}$ & -- & $\mathrm{C}$ & -- & -- & $\mathrm{C}$ & $1 \mathrm{D}$ & 1 & 1 & 1 & 1 & $1 \mathrm{D}$ \\
\hline CT_Hockanum & Urban & 9 & 9 & 9 & 9 & 9 & 9 & 4 & 1 & 3 & 3 & 1 & I & $\mathrm{C}$ & -- & $\mathrm{C}$ & I & -- & -- & 1 & 1 & 1 & 1 & 1 & 1 \\
\hline CT_SalmonHam & Light urban & 4 & 4 & 4 & 4 & 4 & 4 & 4 & 1 & 3 & 3 & 1 & I & $\mathrm{C}$ & -- & $\mathrm{C}$ & -- & -- & $\mathrm{C}$ & 1 & 1 & 1 & 1 & -- & 1 \\
\hline CT_Eightmile & Forested & 4 & 4 & 4 & 4 & 4 & 4 & 3 & 1 & 3 & 3 & 1 & I & $\mathrm{C}$ & -- & $\mathrm{C}$ & -- & -- & -- & 1 & 1 & 1 & -- & -- & 1 \\
\hline CT_Quinnipiac & Urban & 9 & 9 & 9 & 9 & 9 & 9 & 4 & 1 & 3 & 3 & 1 & I & $\mathrm{C}$ & -- & $\mathrm{C}$ & -- & -- & -- & $1 \mathrm{D}$ & 1 & 1 & 1 & 1 & $1 \mathrm{D}$ \\
\hline
\end{tabular}


Table 2. Summary of data collected at each of the Northeast Stream Quality Assessment sites in 2016. - Continued

[Parameters are categorized by the Northeast Stream Quality Assessment study-design components: comprehensive stream water data, focused studies, and ecological surveys. Numerical values in the table indicate the number of times samples were collected/analyzed for each parameter type. "I" indicates an integrated sample. "C" indicates a continuous sample. "D" indicates sites where components of ecological surveys were delayed from August until October 2016. "1iso" indicates that mercury isotopes were also analyzed. States are abbreviated with two-letter postal codes; for example, NH is New Hampshire. POCIS, polar organic chemical integrative sampler; PAH, polycyclic aromatic hydrocarbon; --, not sampled.]

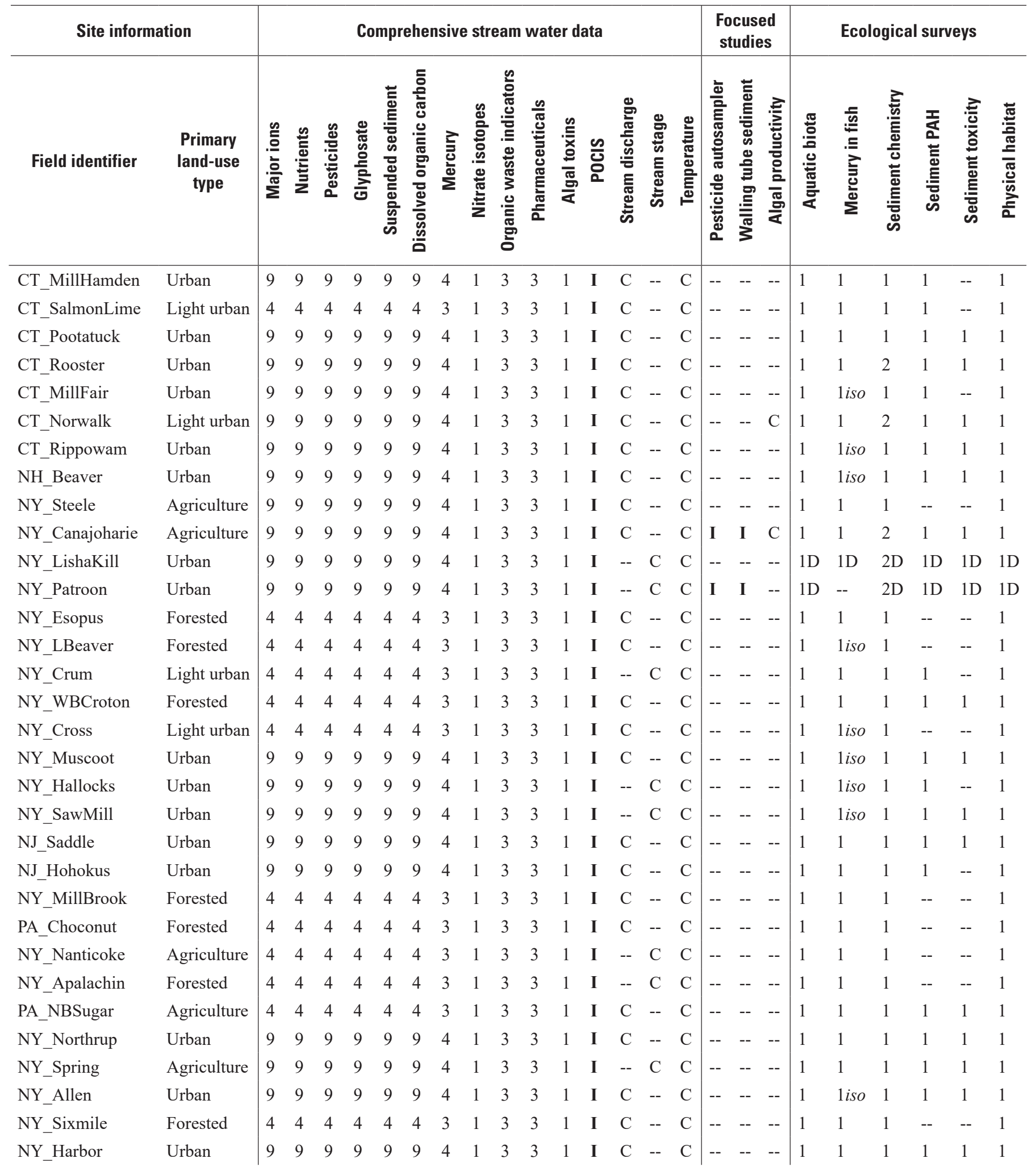


Table 2. Summary of data collected at each of the Northeast Stream Quality Assessment sites in 2016.—Continued

[Parameters are categorized by the Northeast Stream Quality Assessment study-design components: comprehensive stream water data, focused studies, and ecological surveys. Numerical values in the table indicate the number of times samples were collected/analyzed for each parameter type. "I" indicates an integrated sample. "C" indicates a continuous sample. "D" indicates sites where components of ecological surveys were delayed from August until October 2016. "1iso" indicates that mercury isotopes were also analyzed. States are abbreviated with two-letter postal codes; for example, NH is New Hampshire. POCIS, polar organic chemical integrative sampler; PAH, polycyclic aromatic hydrocarbon; --, not sampled.]

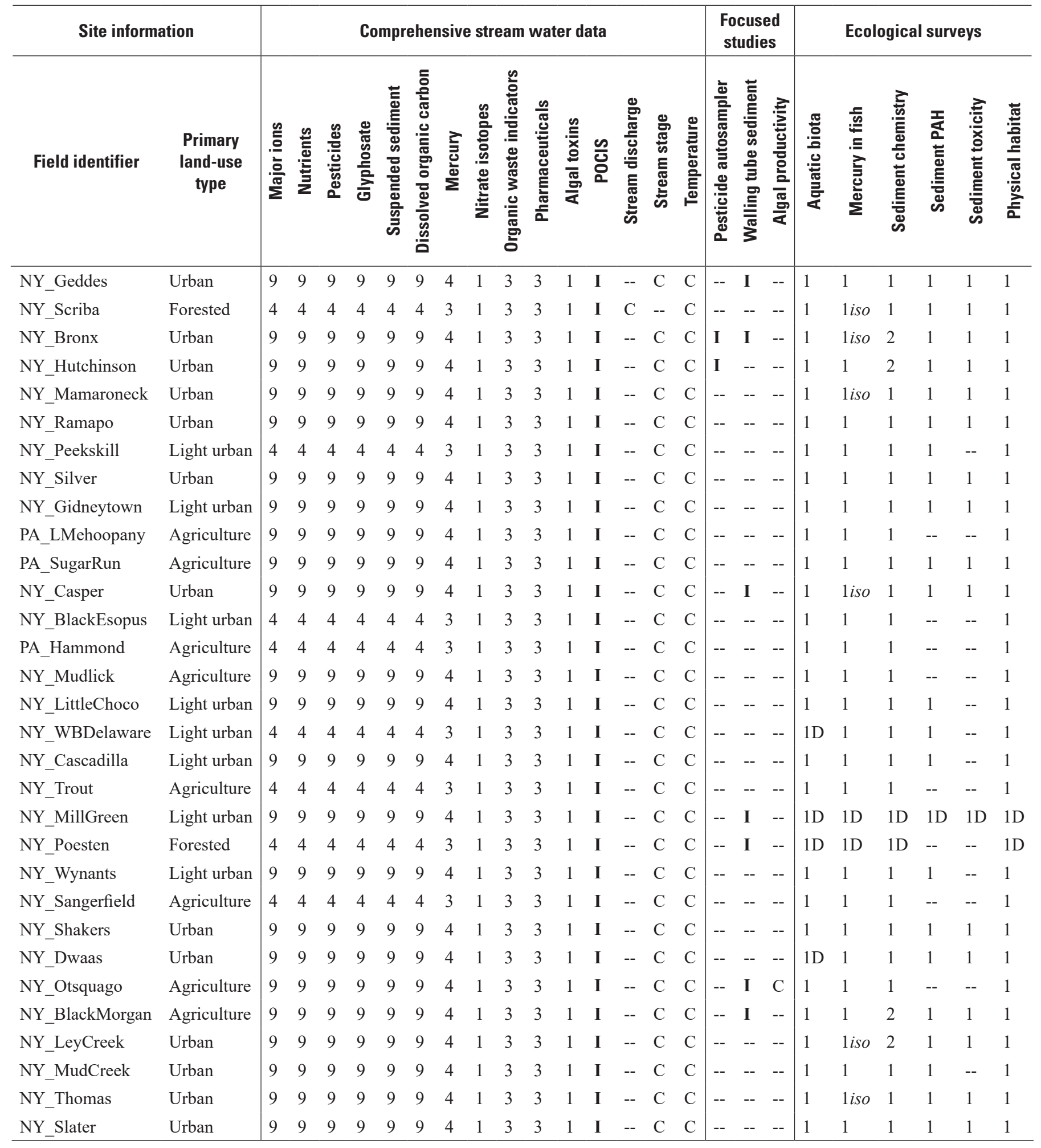


Appendixes 1-2 



\section{Appendix 1. Description of the Sampling Timelines, Matrix, Collection, and Processing for Water, Sediment, and Ecological Samples}

[Appendix tables are available for download at https://doi.org/10.3133/ofr20181183]

\section{Tables}

1.1. Sample matrix for selected sites in the U.S. Geological Survey Northeast Stream Quality Assessment in 2016

1.2. Onset Computer Corporation specifications for the HOBO Water Temp Pro v2 U22 and U20 water level loggers used to monitor continuous water temperature and water level, respectively, at selected stream sites as part of the Northeast Stream Quality Assessment of the U.S. Geological Survey National Water-Quality Assessment Project in 2016

1.3. Description of the data collection and processing steps for water samples collected during the U.S. Geological Survey Northeast Stream Quality Assessment study in 2016

1.4. Description of the bottle types, laboratory schedules, preservation, and shipping protocols by parameter group collected by the U.S. Geological Survey Northeast Stream Quality Assessment in 2016 


\section{Appendix 2. Description of the U.S. Geological Survey National Water Quality Laboratory Schedules Used for Water, Sediment, and Periphyton}

[Appendix tables are available for download at https://doi.org/10.3133/ofr20181183]

\section{Tables}

2.1. U.S. Geological Survey National Water Quality Laboratory Schedule 2590 for major ions in water

2.2. U.S. Geological Survey National Water Quality Laboratory Schedule 2711 for nutrients in water

2.3. U.S. Geological National Water Quality Laboratory Schedule 2437 for current-use pesticides in water

2.4. U.S. Geological Survey National Water Quality Laboratory Schedule 2440 for pharmaceutical compounds in water

2.5. U.S. Geological Survey National Water Quality Laboratory Schedule 4433 for organic wastewater indicator compounds in water

2.6. U.S. Geological Survey National Water Quality Laboratory Schedule 5433 for organic wastewater indicator compounds in bed sediment

2.7. U.S. Geological Survey National Water Quality Laboratory Schedule 5506 for semi-volatile organic compounds in bed sediment

2.8. U.S. Geological Survey National Water Quality Laboratory Schedule 8093 for halogenated organic compounds in bed sediment

2.9. U.S. Geological Survey National Water Quality Laboratory Schedule 6434 for hormone compounds in bed sediment

2.10. U.S. Geological Survey National Water Quality Laboratory Schedule 1632 for chlorophyll $a$, pheophytin $a$, and ash-free dry mass in periphyton 


\section{References Cited}

Arar, E.J., and Collins, G.B., 1997, U.S. Environmental Protection Agency method 445.0 - In vitro determination of chlorophyll $a$ and pheophytin a in marine and freshwater algae by fluorescence (rev. 1.2, September 1997): Cincinnati, Ohio, U.S. Environmental Protection Agency, National Exposure Research Laboratory, Office of Research and Development, $22 \mathrm{p}$.

Britton, L.J., and Greeson, P.E., eds., 1987, Gravimetric method for biomass, in Methods for collection and analysis of aquatic biological and microbiological samples: U.S. Geological Survey Techniques of Water-Resources Investigations, book 5, chap. A4, p. 139-140. [Also available at https://pubs.er.usgs.gov/publication/twri05A4.]

Burkhardt, M.R., Zaugg, S.D., Smith, S.G., and ReVello, R.C., 2006, Determination of wastewater compounds in sediment and soil by pressurized solvent extraction, solid-phase extraction, and capillary-column gas chromatography/ mass spectrometry: U.S. Geological Survey Techniques and Methods, book 5, chap. B2, 33 p. [Also available at https://pubs.er.usgs.gov/publication/tm5B2.]

Fishman, M.J., ed., 1993, Methods of analysis by the U.S. Geological Survey National Water Quality LaboratoryDetermination of inorganic and organic constituents in water and fluvial sediments; U.S. Geological Survey Open-File Report 93-125, 217 p. [Also available at https://pubs.er.usgs.gov/publication/ofr93125.]

Fishman, M.J., and Friedman, L.C., 1989, Methods for determination of inorganic substances in water and fluvial sediments: U.S. Geological Survey Techniques of WaterResources Investigations, book 5, chap. A1, 545 p. [Also available at https://pubs.er.usgs.gov/publication/twri05A1.]

Foreman, W.T., and Gray, J.L., ReVello, R.C., Lindley, C.E., Losche, S.A., and Barber, L.B., 2012, Determination of steroid hormones and related compounds in filtered and unfiltered water by solid-phase extraction, derivatization, and gas chromatography with tandem mass spectrometry: U.S. Geological Survey Techniques and Methods, book 5, chap. B9, 118 p., accessed April 3, 2015, at https://pubs.usgs.gov/tm/5b9/.

Furlong, E.T., Noriega, M.C., Kanagy, C.J., Kanagy, L.K., Coffey, L.J., and Burkhardt, M.R., 2014, Determination of human-use pharmaceuticals in filtered water by direct aqueous injection-High-performance liquid chromatography/ tandem mass spectrometry: U.S. Geological Survey Techniques and Methods, book 5, chap. B10, 49 p., accessed April 3, 2015, at http://dx.doi.org/10.3133/tm5B10.
Furlong, E.T., Werner, S.L., Anderson, B.D., and Cahill, J.D., 2008, Determination of human-health pharmaceuticals in filtered water by chemically modified styrene-divinylbenzene resin-based solid-phase extraction and highperformance liquid chromatography/mass spectrometry: U.S. Geological Survey Techniques and Methods, book 5, chap. B5, 56 p. [Also available at https://pubs.er.usgs.gov/ publication/tm5B5.]

Gellis, A.C., Fuller, C.C., and Van Metre, P.C., 2017, Sources and ages of fine-grained sediment to streams using fallout radionuclides in the midwestern United States: Journal of Environmental Quality, v. 194, p. 73-85, accessed June 2017 at http://dx.doi.org/10.1016/j.jenvman.2016.06.018.

Mahler, B.J., Van Metre, P.C., Wilson, J.T., Musgrove, M., Zaugg, S.D., and Burkhardt, M.R., 2009, Fipronil and its degradates in indoor and outdoor dust: Environmental Science \& Technology, v. 43, no. 15, p. 5665-5670. [Also available at https://doi.org/10.1021/es901292a.]

O’Dell, J.W., 1993, EPA Method 365.1-Determination of phosphorus by semi-automated colorimetry (rev. 2.0, August 1993): Cincinnati, Ohio, U.S. Environmental Protection Agency, Office of Research and Development, 17 p.

Patton, C.J., Kryskalla. J.R., 2003, Methods of analysis by the U.S. Geological Survey National Water Quality Laboratory-Evaluation of alkaline persulfate digestion as an alternative to Kjeldahl digestion for determination of total and dissolved nitrogen and phosphorus in water: U.S. Geological Survey Water-Resources Investigations Report 03-4174, 33 p. [Also available at https://pubs.er.usgs.gov/publication/ wri034174.]

Patton, C.J., and Kryskalla, J.R., 2011, Colorimetric determination of nitrate plus nitrite in water by enzymatic reduction, automated discrete analyzer methods: U.S. Geological Survey Techniques and Methods, book 5, chap. B8, 34 p. [Also available at https://pubs.er.usgs.gov/publication/ tm5B8.]

Sandstrom, M.W., Kanagy, L.K., Anderson, C.A., and Kanagy, C.J., 2015, Determination of pesticides and pesticide degradates in filtered water by direct aqueous-injection liquid chromatography-tandem mass spectrometry: U.S. Geological Survey Techniques and Methods, book 5, chap B11, 54 p., accessed December 8, 2015, at http://dx.doi. org/10.3133/tm5B11.

Wagner, R.J., Moran, P.W., Zaugg, S.D., Sevigny, J.M., and Pope, J.M., 2014, Contaminants of emerging concern in the lower Stillaguamish River Basin, Washington, 2008-2011: U.S. Geological Survey Open-File Report 2014-1028, 14 p., accessed August 2016 at https://dx.doi.org/10.3133/ ofr20141028. 
Zaugg, S.D., Burkhardt, M.R., Burbank, T.L., Olson, M.C., Iverson, J.L., and Schroeder, M.P., 2006, Determination of semivolatile organic compounds and polycyclic aromatic hydrocarbons in solids by gas chromatography/ mass spectrometry: U.S. Geological Survey Techniques and Methods, book 5, chap. B3, 44 p. [Also available at https://pubs.er.usgs.gov/publication/tm5B3.]

Zaugg, S.D., Smith, S.G., and Schroeder, M.P., 2006, Determination of wastewater compounds in whole water by continuous liquid-liquid extraction and capillary-column gas chromatography/mass spectrometry: U.S. Geological Survey Techniques and Methods, book 5, chap. B4, 30 p. [Also available at https://pubs.er.usgs.gov/publication/ tm5B4.] 
For more information about this report, contact: Director, New England Water Science Center U.S. Geological Survey

10 Bearfoot Road

Northborough, MA 01532

dc_nweng@usgs.gov

or visit our website at

https://newengland.water.usgs.gov

Publishing support provided by the Pembroke Publishing Service Center 
$\stackrel{0}{F}$

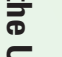

is

要

高. 